\title{
TEOLOGI RELIGIONUM: DILEMATIKA PENDIDIKAN AGAMA KRISTEN DALAM MENENTUKAN SIKAP KEIMANAN
}

\author{
Demsy Jura \\ Universitas Kristen Indonesia \\ demsy.jura@uki.ac.id
}

\begin{abstract}
Abstrak
Manusia adalah satu-satunya mahluk hidup yang memiliki kemampuan untuk mengenal hal yang berifat religius; kenyataan ini membuat ia menjadi mahluk yang berkemampuan dalam memahami Tuhan dengan segala aspek-aspek ilahi yang ada didalamnya. Hal ketuhanan pada akhirnya memberikan inspirasi kepada manusia dalam menjalani kehidupan yang lebih bermartabat, melalui keyakinan keagamaan yang dimilikinya. Dengan demikian maka kemampuan dalam memahami agama, telah menempatkan manusia poda posisi yang lebih tinggi dari mahluk lainnya.

Keyakinan keagaman menjadi bagian yang tak terpisahkan dalam kehidupan umat manusia; itulah sebbanya melalui hal keyakinan inilah maka seseorang perlu membangun hubungan yang harmonis diantara sesama. Upaya membangun hubungan yang harmonis diantara para pemeluk agama terus diupayakan ditengah-tengah gencarnya gerakan fundamentalisme dan fanatisme para pengikut atas agama yang dianutnya. Upaya dialog antar umat beragama merupakan salah satu cara untuk meredam kekisruan terebut.

Teologi Religionum merupakan cabang ilmu teologi yang membahas bagaimana respons teologi kekristenan terhadap fakta pluralisme agama diluar agama Kristen. Tujuan dari teologi religionum ini adalah bagaimana kekristenan melihat dan memberikan penilaian teologis terhadap agama-agama lain. Masing-masing agama memiliki keunikannya tersendiri dan perlu dihargai eksistensinya; itulah sebabnya diperlukan suatu cara untuk hal yang dimaksud.

Tipologi Tripolar merupakan sebuah istilah yang akrab dengan studi agama-agama, dan juga berkaitan dengan perkembangan teologi religionum. Tipologi Tripolar bermaksud memberikan penjelasan terperinci mengenai teologi religionum yang dimaksudkan tersebut. Tipologi yang dimaksudkan tersebut itu digunakan sebagai standar di dalam studi teologi agama-agama, dan hingga kini masih banyak dipakai dalam diskursus teologi agama-agama. Tipologi Tripolar digunakan untuk memetakan beragam pendekatan para teolog dan non-teolog Kristen mengenai relasi kekristenan dengan agama-agama lain. Pemetaan ini didasarkan pada kesamaan dan perbedaan cara pandang mereka terhadap agama-agama lain di luar Kristen. Alan Race mempopulerkan istilah Tipologi Tripolar yang menunjuk kepada tiga hal pokok dalam membahas teologi agama-agama yang dimaksud, yaitu: eksklusivisme, Inklusivisme dan Pluralisme.

Berkaitan dengan Pendidikan Agama Kristen (PAK), maka kehadiran teologi religionum menjadi dilematika dalam pelaksanaan PAK; sebab PAK menuntut pengakuan mutlak bahwa Yesus Kristus adalah Tuhan dan Juruselamat umat manusia. Apapun alasan yang dipergunakan dalam membangun jembatan komunikasi dengan sesama pemeluk agama; PAK memberikan sikap yang jelas berkaitan dengan posisi keimanan orang percaya. Jadi hubungan dengan sesama pemeluk agama wajib dijaga dalam konteks fakta kemajemukan dalam masyarakat, namun keyakinan iman kepada Kristus tidak bisa diabaikan begitu saja.
\end{abstract}

Kata Kunci: Dilematika, Keimanan, Pendidikan Agama Kristen, Teologi Religionum, 


\section{Pendahuluan}

Manusia adalah satu-satunya mahluk hidup yang memiliki kemampuan untuk mengenal hal yang berifat religius. Keadaan ini membuat ia menjadi mahluk yang berkemampuan memahami Tuhan dengan segala aspek-aspek ilahi yang ada didalamnya. Itulah sebabnya ketika Mircea Eliade ${ }^{1}$ mempopulerkan konsep homo religiosus ${ }^{2}$ maka banyak kajian tentang eksistensi manusia sebagai mahluk yang beragama menjadi hal yang menarik untuk dibahas. Ada argumen yang kuat untuk berpendapat bahwa homo sapiens juga merupakan homo religiosus. Manusia mulai menyembah dewa-dewa segera setelah mereka menyadari diri sebagai manusia; mereka menciptakan agama-agama pada saat yang sama ketika mereka mencipta-kan karya-karya seni. Hal ini bukan karena mereka ingin menaklukkan kekuatan alam; keimanan awal ini mengekspresikan ketakjuban dan misteri yang senantiasa merupakan unsur penting pengalaman manusia tentang dunia yang menggetarkan namun indah. Sebagaimana seni, agama merupakan usaha manusia untuk menemukan makna dan

\footnotetext{
1 Mircea Eliade (1907-1986) seorang filsuf, sejarawan berkebangsaan Rumania yang menjadi profesor di Chicago University. Pengaruh pemikiran-nya cukup besar dalam studi agamaagama ketika ia menjabat sebagai kepala Departemen Sejarah Agama di universitas tersebut. Ia juga menjabat kepala editor pada Macmillan's Encyclopedia of Religion, dan pemimpin jurnal ilmiah History of Religions dan The Journal of Religion. Analisis agama Eliade meng-asumsikan keberadaan "yang sakral" sebagai objek pemujaan kemanusiaan religius.

${ }^{2}$ Homo religiosus adalah istilah yang menunjuk kepada seseorang yang perilaku dan pikirannya dimotivasi sepenuhnya oleh ide-ide agama. Para ahli bidang agama menggunakan istilah ini dalam dalam pengertian yang berbeda, namun menuju pada satu rujukan, yaitu manusia dan agama.
}

nilai kehidupan, di tengah derita yang menimpa wujud kasatnya.

Kemampuan keagamaan yang dimiliki manusia telah membawanya kepada hidup yang mengenal akan Tuhan sebagai pribadi yang disembah. Kemampuan manusia yang yang diberikan Tuhan memang sangatlah besar dan melebihi ciptaan Tuhan lainnya, namun terbatas dalam upaya memahami sesuatu yang ada; dan itulah sebabnya hal tersebut telah membuatnya percaya akan suatu hal yang berkuasa dan berada diatasnya.

Agama menjadi hal penting dalam upaya memahami sesuatu yang tidak dapat dipahaminya tersebut. Hal ketuhanan pada akhirnya memberikan inspirasi pada manusia dalam menjalani kehidupan yang lebih bermartabat. Dengan demikian maka kemampuan dalam memahami agama, telah menempatkan manusia poda posisi yang lebih tinggi dari mahluk lainnya. A. M. Romly, dalam buku Fungsi Agama bagi Manusia: Suatu Pendekatan Filsafat, menyatakan bahwa: "Agama merupakan kiprah manusia yang bersumber pada sikap percaya kepada Tuhan. Sikap percaya kepada Tuhan tersebut disertai dengan penyerahan diri secara menyeluruh, yang diwujudkan antara lain dengan kepatuhan terhadap ajaranajarannya." ${ }^{4}$ Pernyataan tersebut membenarkan akan adanya konsep ketuhanan dalam diri seseorang, yang mana hal itu diimplementasikan dalam bentuk kepercayaannya dalam beragama.

Dewasa ini kebangkitan agamaagama sebagai upaya menekan radilkalisme telah berjalan dengan cepat.

\footnotetext{
${ }^{3}$ Karen Amstrong, Sejarah Tuhan (Bandung: PT. Mizan Pustaka, 2012), 12.

4 A.M Romly, Fungsi Agama Bagi Manusia : Suatu Pendekatan Filsafat (Jakarta: Bina Rena Pariwara, 1999), 1.
} 
Tren harmonisasi antar agama terlihat dengan jelas namun hal yang terjadi sebagai dampak dari proses tersebut dapat dilihat dari adanya upaya untuk membangun konsep kesatuan agamaagama. Fakta kemajemukan tersebut tidak bisa dipungkiri. Nampaknya, kecenderungan manusia dalam hal keyakinan keagamaan sedang berubah arah; dari hal yang bersifat wahyu kepada hal yang bersifat pengetahuan dan logika. Hal ini merupakan tantangan kekristenan dalam peradaban umat manusia.

Ketika orang melihat kemungkinan pertama, yaitu membangun konsep kesatuan agama-agama, maka hal-hal yang bersifat esensial suatu agama akan terabrasi karena upaya penyatuan agamaagama tidak mungkin terjadi selama hal esensial itu terus dipegang karena hal tersebut pada kenyataannya telah menjadi penghalang. Lagi pula akan memunculkan agama baru, yang me-rupakan hasil penyatuan tersebut. Sebaliknya jika konsep kedua diterapkan, yaitu kemajemukan agama disarankan dalam kehidupan bermasyarakat maka yang diperlukan adalah sikap toleransi, dialog dan bahkan upaya menghargai satu agama dengan agama lainnya; tanpa membuat keyakinan agamanya berkurang kaidah imannya. Dan nampaknya konsep inilah yang dipegang oleh banyak orang.

Guna memperlengkapi data informasi mengenai teologi religionum, dalam penulisan karya tulis ini, maka penulis memandang perlu menyampaikan informasi mengenai sejarah perkembangan teologi religionum. Tentunya dengan mempergunakan data kepustakaan yang ada, maka diharapkan akan memperoleh informasi selengkapnya mengenai sejarah berdirinya gerakan ini. Upaya untuk menambah kelengkapan data mengenai gerakan ini dilakukan dengan cara me- ngumpulkan sejumlah data yang dianggap perlu. Dengan demikian maka akan diperoleh data yang sesuai dengan harapan.

Upaya membangun hubungan yang harmonis diantara para pemeluk agama terus diupayakan ditengah-tengah gencarnya gerakan fundamentalisme dan fanatisme para pengikut atas agama yang dianutnya. Upaya dialog antar umat bergama merupakan salah satu cara untuk meredam kekisruan ini. Metode dialog antar umat beragama yang pada mulanya hanya sekedar wadah persekutuan dan sebagai ekspresi saling menghargai dan menghormati satu dengan lainnya. Dalam perkembangannya hal tersebut telah berubah menjadi suatu usaha dari masing-masing agama dan antar umat beragama yang lainnya untuk saling mempelajari kesamaan-kesamaan kebenaran yang mereka anut. Dengan upaya yang terus berlanjut itu akan membawa mereka pada sampai tahapan mana mereka dapat saling menerima keabsahan dan kebenaran semua agama, dan hal inilah yang kemudian dikenal sebagai pluralisme agama. ${ }^{5}$

Teologi Religionum atau yang dikenal sebagai teologi agama-agama atau theology of religions; merupakan cabang ilmu teologi yang membahas bagaimana respons teologi kekristenan terhadap fakta pluralisme agama diluar agama Kristen. Tujuan dari teologi religionum ini adalah bagaimana kekristenan melihat dan memberikan penilaian teologis terhadap agama-agama lain. Dengan penilaian yang dimaksudkan tersebut diharapkan kekristenan dapat melihat segi positif dari teologi suatu agama, dan melaluinya diupayakan untuk membangun jembatan komunikasi diantara-

5 Stevri I. Lumintang, Theologia Abu-abu (Malang: Penerbit Gandum Mas, 2004), 14. 
nya. Tentunya hal tersebut akan meredam semangat fundamentalisme yang sesungguhnya sangat membahayakan kehidupan bermasyarakat.

Teologi religionum dianggap oleh sekelompok orang sebagai solusi yang cukup baik dalam usaha membangun hubungan yang lebih harmonis dalam kehidupan bermasyarakat. Teologi religionum memunculkan semangat kebersamaan yang memandang satu agama dengan yang lainnya setara dan tidak ada yang lebih tinggi statusnya dengan agama lainnya. Pola ini akan memberikan rasa aman dan tidak ada unsur saling curiga satu dengan yang lainnya. Namun demikian perlunya sikap yang dewasa dan cermat dalam memahami teologi religionum sebab ketika membicarakan suatu agama, maka tidak boleh menyinggung agama yang lainnya, dan bahkan tidak boleh memandang agama sendiri lebih baik dari agama orang lain.

Teologi religionum pada dasarnya merupakan upaya dari dalam komunitas keagamaan tertentu untuk melakukan refleksi atau pemikiran yang runtut tentang kesadaran baru sebagai upaya untuk memberi respon terhadap persoalan pluralisme. Manusia yang berasal dari berbagai latar belakang akan terbantu dalam upaya membangun komunikasi dengan sesama apabila menerapkan prinsip-prinsip yang penting dalam keyakinan teologi religionum.

Teologi religionum sesungguhnya tidak lain sebagai upaya refleksi teologis untuk menempatkan pluralisme sebagai pusat perhatian dan pusat persoalan antar agama. Teologi religionum harus mempunyai pijakan pada realitas karena ia memberikan penjelasan tentang teologi agama-agama yang cukup beragam dan harus dapat diterima oleh masyarakat. Teologi religionum merupakan cara yang ditemukan manusia dalam upaya mencari makna teologis dari pluralisme agamaagama tersebut. Dan tugas esensial dari agama adalah membuat dirinya relevan dengan keadaan, teologi religionum merupakan respon penganut suatu agama terhadap keseluruhan masa depan masyarakat maupun agama-agama.

\section{Latar Belakang Munculnya Teologi Religionum}

Teologi Religionum dipandang sebagai salah satu solusi dalam upaya tulus untuk mempertahankan kerukunan antar umat bergama. Hal itu memungkinkan karena keyakinan teologi religionum dipandang sebagai upaya membangun jembatan komunikasi dan juga warna toleransi yang didambakan oleh orangorang tertentu karena menginginkan adanya kehidupan yang akur dan berdampingan secara damai antar sesama pemeluk agama.

Salah satu tokoh penting dari gerakan teologi religionum, Th. Sumartana dalam buku, Meretas Jalan Teologia Agama-Agama di Indonesia, mengatakan bahwa: Tantangan keagamaan yang mendasar yang kita hadapi sekarang ini bisa kita ungkap dengan satu kata, yaitu pluralisme. Tidak ada maksud mengatakan bahwa pluralisme merupakan satu-satunya tantangan akan tetapi bila tantangan itu tidak diperhatikan dengan sungguh-sungguh, maka agamaagama akan kehilangan persepsi yang benar tentang dunia dan masyarakat sekarang. Pluralisme telah menjadi ciri esensial dari dunia masyarakat sekarang. Dunia telah menjadi satu dan menjadi kampung kecil di mana umat manusia hidup bersama di dalamnya." "Sumartana

\footnotetext{
${ }^{6}$ Th. Sumartana, Meretas Jalan Teologia AgamaAgama di Indonesia (Jakarta: BPK. Gunung Mulia, 2007), 18.
} 
menyatakan harapannya terhadap pluralisme dan ia berharap supaya pluralisme mendapat tempat dalam kehidupan masyarakat; baginya pluralisme merupakan ciri utama masyarakat modern saat ini. Teologi religionum pada dasarnya merupakan upaya dari dalam komunitas keagamaan tertentu untuk melakukan refleksi atau pemikiran yang runtut tentang kesadaran baru sebagai upaya untuk memberi respon terhadap persoalan pluralisme. Teologi religionum tak lain adalah upaya refleksi teologis untuk menempatkan pluralisme sebagai pusat perhatian dan pusat persoalan. Dalam membangun gerakannya, teologia religionum harus mempunyai pijakan pada realitas masyarakat yang ada, dimana teologia religionum merupakan sebuah usaha untuk mencari makna teologis dari pluralisme agama-agama yang dimaksud tersebut.

Tugas pokok dari agama adalah membuat dirinya relevan dengan keadaan dan zaman dalam kehidupan umat manusia, dan teologi religionum merupakan respon terhadap keseluruhan masa depan masyarakat maupun agama-agama. Dalam teologi religionum memberikan identitas keagamaan seseorang yang harus tetap terjaga dan terpelihara; tanpa meremehkan dan bahkan bisa menghargai identitas keagamaan orang lain dan integritas agama orang lain. Tentunya hal tersebut akan sangat sulit terlaksana apabila seseorang kurang memahami maksud dan tujuan dari gerakan teologi religionum tersebut. Itulah sebabnya untuk menjamin terjadinya hubungan yang harmonis antar sesama pemeluk agama, maka upaya yang harus dilakukan dalam perumusan teologi religionum haruslah dengan benar-benar berpijak pada kenyataan pluralisme yang berkembang dalam masyarakat, dikontrol supaya tetap terkendali dalam jalur yang menghargai agama-agama lainnya, dan juga diawasi sehingga bisa menjadi bahan percakapan yang produktif dan membuahkan hasil yang positif bagi peradaban umat manusia.

Teologi religionum muncul karena pada kenyataannya, hal kemajemukan dalam masyarakat yang terus berkembang dari masa ke masa. Perkembangan pluralistik ini sesungguhnya membutuhkan metodologi yang cocok dalam upaya membangun hubungan kemasyarakatan yang lebih baik, dan pola pendekatan yang tepat untuk menjembatani kemajemukan tersebut akan memberi dampak yang baik pula dalam kehidupan beragama. Hubungan antar umat akan terus terjaga dan terhindar dari fanatisme yang lebih banyak merugikan semua pihak.

Cara yang dianggap mampu menjalin hubungan kemasyarakatan yang lebih baik sebagaimana yang dimaksudkan tersebut diatas adalah dengan melihat kesamaan dan mengabaikan perbedaan antar agama. Dalam hal keagamaan, prinsip kebersamaan hanya dapat terwujud apabila aspek esensial suatu agama tidak dipaksakan kepada agama yang lain. Ketika hal esensial itu dipergunakan dalam membangun hubungan antar umat beragama, maka hampir pasti akan terjadi gesekan; sebagai contoh ketika agama Kristen tetap berpedoman pada Yesus Kristus sebagai jalan keselamatan (lih. Yohanes 14:6), maka agama lainnya akan menunjukkan rasa ketidaksenangannya atas keyakinan esensial tersebut. Kompromi dan membangun dialog menjadi sangat penting untuk mewujudkan kehidupan masyarakat yang baik, aman dan bebas konflik.

Usaha untuk menjaga hubungan antar umat beragam demi kenyamanan dan keamanan suatu komunitas sangat 
diperlukan. Itulah sebabnya beberapa orang telah menunjukkan usahanya untuk membangun hubungan dengan upaya menjembatani hal-hal yang sekiranya dapat memicu masalah antar umat. Berbagai perbedaan yang ada biasanya diupayakan untuk dicari titik temu sehingga hal yang dapat menimbulkan banyak masalah tersebut dapat diatasi. Hal yang paling membahayakan apabila unsur yang sangat esensial dalam suatu agama dikorbankan demi alasan kesatuan dan persatuan; namun juga hal yang harus dipikirkan adalah keunikan setiap agama yang harus tetap dipertahankan. Masalahnya untuk membangun hubungan yang lebih harmonis diantara para pemeluk agama, diperlukan sikap kompromistik yang harus lebih terbuka didalamnya. Jika selama ini selalu berpikir bahwa agamanya adalah yang terbaik, maka kini demi menjaga hubungan tersebut; harusnya pandangan itu diabaikan, dan diganti dengan mengakui bahwa agama lainpun memiliki unsurunsur kebenaran yang patut dihargai. Bagi kaum yang mendukung pluralistik tentunya hal tersebut sangatlah tepat, namun bagi mereka yang lebih kuat keyakinan keagamaannya akan menolak usulan tersebut.

Berbeda dengan ilmu-ilmu agama lainnya; dimana mereka memfokuskan diri pada usaha untuk mempelajari sejarah, ajaran, tradisi dan keyakinan suatu agama; teologi religionum justru lebih mengkonsentrasikan diri pada pemikiran akan hubungan suatu agama dengan agama-agama lainnya. Teologi religionum mempelajari apa peran yang positif yang dapat diperbuat untuk saling memahami perspektif setiap agama dan bagaimana agama-agama yang penuh keunikan dan perbedaan satu dengan lainnya itu dapat hidup berdampingan dan bahkan bisa bekerja sama untuk membangun suatu tatanan dunia yang lebih baik dan bagi kesejahteraan seluruh umat manusia. Itulah sebabnya kehadiran teologi religionum dianggap akan mampu mencairkan kebekuan suasana dialog antar umat beragama yang tadinya berdiri pada dasar saling curiga. Dengan adanya teologi religionum maka hal-hal yang dapat menimbulkan kecurigaan dan pertikaian penganut suatu agam dengan agama lainnya akan diminimalisasi serendah mungkin. Perlu ditegaskan dalam hal ini bahwa kehadiran teologi religionum tidak dengan sendirinya, melainkan telah ada hal-hal lain mendahuluinya.

Jauh hari sebelum istilah teologi religionum diperkenalkan, telah dimulai dengan sejumlah gerakan yang berupaya untuk merumuskan suatu gagasan yang bertujuan dalam upaya membangun jembatan komunikasi antar umat beragama. Ide-ide yang dimaksudkan tersebut telah memberikan inspirasi munculnya teologi religionum. Hal-hal itu merupakan gerakan yang menuju ke arah pengakuan akan eksistensi agama-agama lain pada umumnya. Dengan pengakuan tersebut maka dengan sendirinya suatu agama yang dianggap superior tidak ada. Demikian juga tidak mengakui adanya truth-claim $^{7}$ suatu agama, dimana hal tersebut diuraikan dengan tuntas dalam buku On Conflicting Religious TruthClaims, karya John Hick.

Dengan truth-claim suatu agama atas agama yang lain maka sudah barang

\footnotetext{
7 Istilah truth-claim atau klaim kebenaran sesungguhnya ada dalam setiap agama. klaim eksklusivitas dan absolutisme kebenaran ini kemudian ditopang dengan konsep juridis tentang soteriologi suatu agama. Jika agama Yahudi, dikenal dengan "the chosen people"-nya, yaitu terbatas pada komunitas Yahudi, maka Katolik dikenal dengan doktrin "extra ecclesiam nulla salus", dan Kristen dengan "outside Christianity, no salvation" dimana hanya melalui pengorbanan Yesus Kristus maka seseorang dibenarkan.
} 
tentu akan muncul gejolak dalam masyarakat tertentu. Pertikaian antar agama justru terjadi dan bahkan semakin dalam ketika suatu agama merasa lebih superior atas agama lain-nya. Disatu sisi ada kubu yang menyatakan dirinya sebagai agama yang paling benar, dan setidaknya menempatkan diri sebagai agama superior, sementara pada sisi yang lain, suatu agama akan menolak claim superioritasnya tersebut. Hal seperti inilah yang seringkali membuat terjadinya masalah dalam upaya membangun hubungan yang harmonis diantara para pemeluk agama.

\section{Teologi Religionum}

Emile Durkheim, sosiolog Jerman dalam buku Sejarah Agama: The Elementary Form of Religious Life, mengatakan: "Agama tidak lain adalah masyarakat itu sendiri" Karena agama merupakan kesadaran bersama (collective conciousness) masyarakat yang telah dieksternalisasikan, diobjektivasikan, diinternalisasikan dan ditransformasikan . Dalam kajian suatu keyakinan, Peter Berger menjelaskan bahwa: "Eksternalisasi adalah pencurahan ke-diri-an secara terus menerus ke dalam dunia. Melalui pencurahan ini seseorang menghasilkan sesuatu; baik itu yang berbentuk fisis maupun mental. Bagi manusia, eksternalisasi ini adalah suatu keharusan, sebab eksternalisasi ini merupakan tuntutan dari kodrat manusiawi, yang memang belum sempurna semenjak

${ }^{8}$ Emile Durkheim, Sejarah Agama: The Elementary Form Of Religious life (Yogyakarta: Isrcisod, 2001), 67.

${ }^{9}$ Peter L. Berger, Langit Suci Agama Sebagai Realitas Sosial (Jakarta: Penerbit LP3ES, 1991), 4-5. ia dilahirkan. ${ }^{10}$ Eksternalisasi itulah yang membuat seseorang memeluk suatu kepercayaan. Obyektifasi adalah pentransformasian produk-produk yang dihasilkan dari proses eksternalisasi yang menjadi sesuatu yang bukan hanya ciptaan manusia, tetapi juga sesuatu yang berbeda dari penciptanya. ${ }^{11}$ Internalisasi merupakan peresapan kembali dari apa yang dihasilkan oleh manusia yang kemudian ditransformasikan kembali ke dalam struktur kesadaran manusia. ${ }^{12}$ rotasi itulah yang memberikan kesadaran kepada manusia untuk memeluk suatu kepercayaan. Kesadaran bersama itu lahir sebagai upaya manusia mengatasi pelbagai persoalan yang paling dasar (ultimate concern) dalam hidup-nya. ${ }^{13}$ Itulah sebabnya agama menjadi sesuatu yang sangat penting dan tidak dapat dipisahkan dalam kehidupan umat manusia. Hal agama yang sangat penting itu dikarenakan menyangkut kehidupan esensial seseorang. Agama menjadi hal yang penting dalam kehidupan seseorang, termasuk didalamnya akan memberikan pengaruhi yang cukup berar dalam pola kehidupan. Terkadang agama mampu membuat seseorang berpikir dan bertindak sesuai dengan apa yang diisyaratkan dalam pengajaran doktrinnya.

Pembahasan tentang teologi religionum tidak lepas dari perkembangan agama dari masa kemasa. Pada masa sekarang diperlukan suatu upaya untuk menyamakan presepsi tentang kehidupan beragama secara menyeluruh dalam kehidupan masyarakat. Agama yang harusnya menjadi solusi atas setiap permasalahan dan pergumulan umat manusia

\footnotetext{
${ }^{10}$ Ibid.

${ }^{11}$ Ibid.

${ }^{12}$ Ibid.

${ }^{13}$ Robert N. Bellah, Religi Religi Tokugawa AkarAkar Budaya Jepang (Jakarta: Gramedia, 1992), $10-11$
} 
terkadang dianggap bermasalah hanya karena tidak ditempatkan pada tempat yang sebagaimana mestinya. Pergerakan zaman telah memberikan banyak perubahan dalam kehidupan manusia, termasuk didalamnya kemampuan manusia yang lebih dewasa dalam menilai suatu agama.

Teologi religionum nampaknya berupaya memberikan solusi atas permasalahan yang dihadapi oleh manusia yang berkaitan dengan relasi antar agama didalam masyarakat. Ada upaya membangun jembatan komunikasi supaya harmonisasi hidup terpelihara dengan baik. Istilah teologi religionum terdiri dari dua kata, yaitu theologi dan religionum. Istilah Teologi berasal dari kata Yunani Theos yang berarti Allah dan Logos, yang kata logos sendiri artinya Firman atau Kebenaran yang dinyatakan. ${ }^{14}$ Dengan demikian maka Teologi berarti suatu pernyataan atau interprestasi kebenaran tentang Allah. Jadi Theology is taught by God, teaches of God, and leads to God. $^{15}$ Selanjut-nya istilah Religionum berasal dari kata Religions yang artinya agama-agama. Dengan demikian teologi religionum atau Theology of Religions dapat dipahami sebagai teologi agama-agama.

Penjelasan tersebut diatas setidaknya dapat memberikan pengertian yang baik mengenai teologi religionum. Dalam upaya memberikan pemahaman yang lebih baik lagi mengenai teologi religionum, maka dalam pidato pengukuhan Guru Besar ilmu teologi di UKSW, John Titaley, mengatakan bahwa: "Teologi religionum dikembang-

\footnotetext{
${ }^{14}$ Barclay M. Newman, A Consice Greek-English Dictionary of the New Testament (Stuttgart: Deutsche Bibelgesellschaft, tt), 100.

15 D. F. Wright, "Theology," New Dictionary of Theology, ed. by Sinclair B. Ferguson (Leicester: Inter-Varsity Press, 1994), 681.
}

kan dengan maksud untuk menemukan makna keberadaan agama-agama yang lain. Untuk maksud tersebut teologi religionum mengkonsentrasikan diri pada dua hal: pandangan tentang Tuhan dan pandangan tentang sesama. ${ }^{16}$ Jadi upaya memperkenalkan teologi religionum guna memberikan makna eksistensi dari agama-agama. Dengan demikian maka setiap agama dapat dipahami dengan benar dan tanpa prasangka sehingga dengan pemahaman tersebut akan memberikan hubungan yang harmonis diantara umat beragama.

\section{Universalisme}

Universalisme termasuk hal yang paling banyak dibahas dalam kajian mengenai agama-agama. Istilah universalisme berasal dari kata bahasa Latin universum yang berarti alam semesta dunia, yang mana kata tersebut dikenal dalam istilah bahasa Inggris sebagai universal. Kata yang dimaksudkan tersebut dapat berarti konsep umum yang dapat diterapkan pada sisi mana pun. ${ }^{17}$ Selain memiliki beberapa pengertian dalam bidang hukum, politik, sosial dan keagamaan, universalisme juga berarti pandangan bahwa semua manusia akhirnya diselamatkan. ${ }^{18}$ Salah satu hal yang menarik untuk dikaji adalah universalisme agama, khususnya dalam agama Kristen.

Ketika membicarakan universalisme yang berkaitan dengan kekristenan,

\footnotetext{
16 John Titaley, Menuju Teologi Agama-Agama Yang Kontekstual: Pidato Pengukuhan Guru Besar Ilmu Teologi di UKSW (Salatiga: Fakultas Teologi UKSW, tt.), 3.

17 https://id.wikipedia.org/wiki/Universalisme, Diakses pada hari Senin, tanggal 16 Februari 2018, pukul. 20.30.

18 Gerald O'Collins dan Edward G. Farrugia, Kamus Teologi (Yogyakarta, Penerbit Kanisius, 1996), 345.
} 
maka tokoh penting dalam sejarah gereja, yaitu Titus Flavius Clement (150-215) dan Origen (184-254) tidak bisa diabaikan begitu saja. Kedua tokoh ini dianggap dekat dengan pemahaman Universalisme Kristen, sebab mereka berdua dianggap sebagai pribadi yang menjadi bagian dari pengajaran tersebut. Sebagaimana sudah disinggung di-atas, bahwa universalisme merupakan paham yang percaya bahwa pada akhirnya semua orang akan mendapat bagian pada keselamatan oleh Yesus Kristus; maka anugerah Allah yang besar itu dianggap pada akhirnya dialami oleh semua orang. Dan tulisan ini membatasi pembahasan mengenai universalisme yang dimaksud dalam batasan seputar pemahaman doktrin soteriologi Kristen. Dengan demikian pemahaman universalisme dalam disertasi ini menyangkut hal keselamatan Allah yang universal dimana semua orang akan diselamatkan oleh Tuhan Allah sendiri.

Titus Flavius Clement atau yang dikenal dengan nama Clement dari Alexandria, merupakan filsuf Kristen pertama dan salah satu bapak gereja yang terkenal di gereja Alexandria. Clement dikenal karena usahanya dalam menyatukan filsafat Yunani dengan pengajaran Kristen, dan hal tersebut ternyata membawa dampak positif bagi gereja; sebab karena hal tersebut telah mem-buat sejumlah besar penyembah berhala pada zamannya percaya kepada Kristus. Clement dianggap sebagai tokoh yang kontroversial dalam sejarah gereja, karena ia mencoba membuat kolaborasi teologi Kristen dengan filsafat yang berkembang pada waktu itu. Kolaborasi teologi tersebut memerlukan sikap yang bijak guna melahirkan sesuatu yang baik bagi teologi Kristen itu sendiri. Ketidakmampuan seseorang dalam melakukan kolabrasi tersebut akan berakibat fatal bagi gereja. Clement bahkan dengan gigih menularkan konsep berpikirnya itu kepada para muridnya.

Pada abad ke-2, gereja Mesir mengalami suatu tekanan pemikiran yang luar dari pengajaran sesat Gnostik. ${ }^{19}$ Para pemimpin gereja pada waktu itu harus berhadapan langsung dengan pemikiran Gnostik dan Clement menjadi salah satu yang terlibat didalamnya. Untuk menghadapi berbagai ajaran yang dianggap tidak sesuai dengan ajaran Kristen itu, maka Clement mengajar sejumlah orang untuk pemahaman doktrin Kristen yang lebih baik lagi.

Clement berpendapat bahwa yang dapat dipahami tentang Tuhan adalah SifatNya, dan bukan esnsi dan juga bukan pada hakekat zat-Nya. Bahkan pengetahuan tentang sifat Tuhan itupun bukanlah pengetahuan yang tuntas sebab semua sifat Tuhan juga esensial. ${ }^{20}$ Itulah sebabnya Clement mengajarkan bahwa pengetahuan tentang Tuhan haruslah dicapai melalui Logos, bukan dengan rasional. Selanjutnya ia mengatakan bahwa hubungan manusia dengan Tuhan dicapai melalui Logos itu. Melalui Logos, Tuhan memperlihatkan kekuasaannya, melalui Logos pula mencipta alam semesta, dan melalui Logos pula manusia

\footnotetext{
${ }^{19}$ Gnostik adalah sebuah ajaran yang me-yakini gnosis yaitu pengetahuan sebagai satu-satunya jalan keselamatan, dan untuk memahami hal ketuhanan, maka kaum gnostik mempelajarinya sendiri tanpa bantuan atau perantara rabbi, pendeta, uskup, imam atau pemimpin agama yang lain. Gereja meng-anggap gnostik sebagai aliran sesat dan dianggap berbahaya. Kaum gnostik secara terus menerus mencari kebenaran yang bersumber dari pengetahuan dan kebijaksanaan dari sumber mana pun. Mereka men-campurkan pelbagai ajaran agama. Secara umum dapat dikatakan Gnostisisme adalah agama dualistik, yang dipengaruhi dan memengaruhi filosofi Yunani, Yudaisme, dan Kekristenan.

${ }^{20}$ Demsy J. Jura, Epistemologi Kristen (Jakarta: Departemen Literatur GKKI, 2014), 89.
} 
mengenal Tuhan. Logos digunakan oleh Clement sebagai jembatan antara dunia spritual dan dunia material. ${ }^{21}$

Origen adalah murid Clement yang juga mengajarkan hal universalisme dalam kekristenan. Ia berasal dari keluarga Kristen yang taat, dan merupakan seorang cendikiawan Kristen yang sangat disegani. Origen belajar filsafat di beberapa filsuf terkenal. Karya tulisnya sangat banyak dan diduga mencapai lebih dari 6.000 karya tulis, tapi sayang banyak yang sudah musnah. Di antara karyanya yang paling terkenal adalah Hexapla ${ }^{22}$ yang berisi enam buku penafsiran; First Principles atau Pengantar Ke Dalam Teologi Sistematika dan Against Celsus yaitu buku Apologetika Kristen. Origen menuntut kehidupan yang saleh dan sederhana, serta menjauhi diri dari minuman keras; demikian juga dengan hawa nafsu, sering mengekang diri, berpuasa dan tidur di atas dipan atau tempat tidur tanpa alas. Pola kehidupan yang dianutnya lebih pada pengekangan diri untuk mencapai suatu tingkat kehidupan yang sempurna. Tentunya hal tersebut sangat bertolakbelakang dengan pola hidup yang diterapkan umat manusia pada waktu itu yang sangat menekankan

\footnotetext{
${ }^{21}$ Ibid, hlm. 92

22 Hexapla merupakan salah satu karya terbesar dari Origen, yang hingga sekarang tidak lagi diketahui keberadaannya. Eusebius memberikan informasi bahwa naskah Hexapla yang otentik disimpan di perpustakaan Caesarea itu kemungkinan ikut hancur bersama Caesarea pada tahun 653 yang ketika itu Caesarea dibakar habis oleh pasukan Saracen dari Arab. Hexapla dipandang dapat menolong orang untuk memahami Tanakh Ibrani. Origen telah melakukan penelitian yang mendalam terhadap penyebaran naskah Ibrani, dan dia memfokuskan penelitiannya pada rekonstruksi yang akurat dari naskah Septuaginta. Tujuan utamanya adalah memberikan penerjemahan Tanakh Ibrani yang akurat pada waktu itu dimana sebagian besar kitab telah berbahasa Yunani.
}

hidup dengan berdasarkan hedonisme. ${ }^{23}$ Pengabdiannya menuntut kehidupan saleh dan sederhana begitu menyeluruh dan konsekuen. Pola hidup yang saleh dan sederhana ini, menyebabkan ia sangat dihormati dan dikagumi. Sama dengan Clement gurunya, Origen juga sangat meng-hargai rasio. Dapatlah dikatakan bahwa hanya Origen seorang teolog kreatif yang bernafas dan hidup dalam intelektual Yunani yang juga popular menyerap menyerap pemikiran filsafat Plato dan penerus-penerusnya. Ia berusaha dengan tuntas mengungkapkan iman kepercayaan tradisional dalam alam pikiran Yunani. Origen mempertahankan interpretasi kiasannya tentang Alkitab, yang secara rasional seperti berlawanan dengan keimanan Kristen. ${ }^{24}$ Seperti halnya Clement, Origen juga berpendapat bahwa Tuhan transenden. Pendapatnya tersebut telah memberikan pengaruh besar dalam pengajaran dan diskusi teologi Kristen. Karena Tuhan transenden maka menurut Origen manusia tidak mungkin mampu mengetahui esensi Tuhan, namun demikian dinyatakan bahwa manusia dapat mengkaji Tuhan melalui karyaNya. Menurut Origen dunia ini adalah pertarungan antara kekuatan baik dan kekuatan jahat, kehidupan manusia adalah perjuangan

\footnotetext{
23 Istilah Hedonisme berasal dari kata Yunani yaitu Hedone, yang dapat diartikan sebagai nikmat atau kenikmatan, sehingga secara sederhana istilah ini menunjuk kepada suatu corak budaya yang lebih mengutamakan kesenangan dalam artian yang bersifat materi. Filsafat Hedonisme muncul kira-kira 400 tahun BC, dengan madzhabnya yang bernama Tyrene, dan dirintis oleh Epicurus (341-270 BC), dimana inti ajarannya adalah mengenai etika, dan kebahagiaan hidup adalah kenikmatan; dimana kenikmatan adalah satu-satunya yang baik, serta menjadi awal dan tujuan hidup yang bahagia. (lih. Simon Petrus L. Tjahjadi. Petualangan Intelektual Yogyakarta: Kanisius, 2004, 82-85)

${ }^{24}$ Demsy J. Jura, Epistemologi Kristen 92
} 
tanpa henti. Dalam pergulatan tersebut sesungguhnya keselamatan manusia dibantu oleh malaikat sementara Setan mengajak manusia ke dalam lorong gelap yang penuh dosa. Penyelamatan terakhir diperoleh setelah manusia bersatu dengan Tuhan. $^{25}$

Selanjutnya Origen berpendapat kejahatan memang perlu diadakan oleh Tuhan untuk menunjukkan kepada manusia agar manusia bisa membedakan mana yang baik dan mana yang buruk. Pendapatnya yang lain yaitu bahwa manusia mempunyai kebebasan memilih perbuatannya, memilih yang baik atau melakukan yang buruk. Dan menurutnya bahwa api neraka itu tidak kekal. Origen juga sepaham dengan Clemen berkaitan dengan Universalisme Kristen. ${ }^{26}$

Paham Universalisme menaburkan benih keragu-raguan orang percaya terhadap Firman Allah. ${ }^{27}$ Jika dikatakan orang di luar Kristus bisa diselamatkan, lalu bagaimana dengan perkataan Yesus Kristus bahwa: "Akulah jalan dan kebenaran dan hidup. Tidak ada seorangpun yang datang kepada Bapa, kalau tidak melalui Aku." (Yohanes14:6); juga dengan kesaksian para rasul, "dan keselamatan tidak ada di dalam siapapun juga selain didalam Dia, sebab di bawah kolong langit ini tidak ada nama lain yang diberikan kepada manusia yang olehnya kita dapat diselamatkan." (Kisah Para Rasul 4:12).

Dengan demikian maka paham universalisme menjadikan perkataan Yesus Kristus dan Alktitab sebagai sesuatu yang terucap tanpa makna. Paham universalisme sesungguhnya secara langsung ataupun tidak langsung men-

\footnotetext{
${ }^{25}$ Ibid.

${ }^{26}$ Daniel H. Wirawan, Mengenal Universalisme Kristen (Jakarta: Departemen Literatur GKKI, 2009), 96

${ }^{27}$ Ibid, 109.
}

jatuhkan otoritas Alkitab sebagai firman Allah. Pada akhirnya dapatlah disimpulkan bahwa universalisme adalah suatu paham yang percaya bahwa semua manusia pada akhirnya akan mendapat bagian pada keselamatan oleh Yesus Kristus. Keselamatan yang didapatkan itu adalah anugerah Allah. Dengan kasih Allah inilah maka tidaklah mungkin ada orang yang tidak diselamatkan. Rahmat Tuhan Allah ada dalam setiap orang, dan pada akhirnya kasih sayang Allah itulah maka semua orang diselamatkan.

\section{Pluralisme}

Hal pluralisme bukanlah sesuatu yang baru dalam kehidupan masyarakat Indonesia. Kemajemukan dalam berbagai aspek nyata sekali bagi bangsa ini. Dengan beraneka ragam suku, bahasa dan kebudayaan sesungguhnya membuat Indonesia menjadi salah satu negara yang patut dijadikan pusat pembelajaran kemajemukan dan bahkan pluralisme dalam hal agama. Intelektual Muslim yang banyak membicarakan tentang pluralisme, M. Jadra, dalam buku Pluralisme Baru dan Cinta Kebangsaan, berkata: "Masyarakat Indonesia telah sejak berabad-abad yang lalu hidup dalam kemajemukan dan berbasis pada multikultural lapisan etnisitas dan agamaagama." ${ }^{28}$ Keragaman suku dan ras yang ada di Indonesia merupakan sebuah kekayaan khasanah, namun juga sebuah tantangan yang harus dihadapi. Dalam keberagaman inilah seringkali benturan terjadi dan hal-hal yang terkadang dianggap tidak perlu terjadi, dapat pula terjadi. Akibatnya konflik yang muncul sebagai akibat dari keberagaman tersebut tumbuh subur. Itulah sebabnya diperlu-

28 M. Jadra, Pluralisme Baru dan Cinta Kebangsaan (Bandung: Penerbit Mizan, 1991), 295. 
kan cara yang baik dalam menangani setiap perbedaan yang ada.

Pembahasan mengenai pluralisme seringkali menjadi tumpang tindih karena istilah pluralitas dan pluralisme, sering muncul dalam pembahasan yang dimaksud. Secara etimologis, kedua kata tersebut berasal dari kata dasar yang sama, yaitu plural yang merupakan terjemahan langsung dari bahasa Inggris, plurality dan pluralisme. Kata plurality atau pluralitas dalam kamus berarti kondisi majemuk atau berbilang. Sedangkan kata pluralism atau pluralisme dalam Oxford Dictionary bermakna ganda, yaitu: (a) the existence in one society of a number of groups that belong to different races or have different political or religious beliefs. (b) the principle that these different groups can live together in peace in one society. ${ }^{29}$ Dapatlah dikatakan bahwa pluralisme merupakan keberadaan suatu kelompok yang berbeda dari segi etnik, politik dan keyakinan dalam suatu masyarakat; juga suatu prinsip ataupun pandangan yang menyatakan bahwa kelompok-kelompok yang berbeda tersebut hidup dengan dalam dalam suatu komunitas.

Kata pluralism yang berarti plural atau beragam, jamak, atau majemuk, yang secara secara terminologis dikenal sebagai pluralisme, sesungguhnya dapat dipahami sebagai suatu pandangan atau paham yang memiliki prinsip bahwa keanekaragaman tersebut janganlah menjadi penghalang untuk bisa hidup berdampingan secara damai dalam satu

29 Paul Procter (ed), Longman Dictionary Of Contemporary English (Beirut: Librairie Du Liban, 1990), 836. Lihat juga, Oxford Advanced Learner's Dictionary, (New York: Oxford University Press, 1995), 889. masyarakat yang sama. ${ }^{30}$ Jadi keberagaman yang ada harusnya membuat hal yang berbeda, sekalipun dalam prinsip yang kokoh; tidaklah membuatnya bermasalah dalam hal membangun hubungan yang lebih harmonis. Sedangkan pluralisme agama adalah kondisi hidup bersama atau koeksistensi antar agama dalam arti yang luas; yang berbeda-beda dalam satu komunitas dengan tetap mempertahankan ciri-ciri spesifik atau ajaran masing-masing agama. $^{31}$

Lorens Bagus dalam Kamus Filsafat menjelaskan pluralisme sebagai pandangan yang berupaya membenarkan keberagaman filsafat, dengan menegaskan bahwa semua kebenaran bersifat relatif, dan menganggap semua keyakinan filosofis dan religius dalam pengertian relativisme murni, sebagai pendapatpendapat pribadi yang semuanya mempunyai nilai yang sama. ${ }^{32}$ Selanjutnya Sudiarjo, dalam buku yang berjudul Dialog Intra Religious mengatakan: "Pluralisme juga sering digunakan untuk menunjuk pada makna realitas keragaman sosial sekaligus sebagai prinsip atau sikap terhadap keragaman itu. Pluralisme sebagai bentuk pe-mahaman modern yang bertujuan menciptakan komunikasi untuk menjembatani jurang ketidaktahuan dan kesalahpahaman timbal-balik antara budaya dunia yang berbeda dan membiarkan mereka bicara dan mengungkapkan pandangan mereka dalam bahasanya sendiri. ${ }^{33}$ Kehidupan manusia

30 Mundzirin Yusuf, Islam dan Budaya Lokal (Yogyakarta: Pokja Akademik Universita Islam Negeri Sunan Kalijaga, tt), 30.

31 Anis Malik Thoha, Tren Pluralisme Agama: Tinjauan Kritis (Jakarta: Perspektif Kelompok Gema Insani, 2005), 14.

${ }^{32}$ Lorens Bagus, Kamus Filsafat (Jakarta: PT Gramedia Pustaka Utama, 2002), 855.

${ }^{33}$ Sudiarjo, Dialog Intra Religious, (Yogyakarta: Kanisus, 1994), 33-34. 
dalam dunia modern terkadang menimbulkan konflik karena pemahaman filosofis yang telah bergeser dalam segala bidang. Dari religionitas ke pada rasionalitas, dari komunitas kepada individualitas; hal-hal ini sesungguhnya telah menjadi katalisator tumbuh sumbur berkembangnya paham pluralisme.

Ketika modernitas terus bertumbuh maka manusia membutuhkan cara untuk tetap menjalankan kehidupan normalnya, dan dalam aspek keagamaan, modernitas telah menimbulkan pemahaman dan sikap agamawi yang berbeda dengan kondisi masyarakat yang tradisional. Pada masyarakat yang tradisional, toleransi dijunjung tinggi. Sebaliknya individualitas dan juga pemahaman yang fundamental atas suatu agama setidaknya telah melahirkan manusia-manusia yang memiliki fanatisme tersendiri atas agama yang dianut. Fungsi dari teologi religionum adalah mencoba untuk meminimalisir setiap konflik yang ada. Dengan membangun hubungan antar agama yang lebih harmonis, diatas dasar kesamaan humanistik maka diharapkan konflik dapat diredam.

Pengaruh pluraisme saat ini begitu keras dan telah masuk dalam berbagai aspek kehidupan umat manusia. Pluralisme telah menjadi semacam gaya hidup yang memberikan dampak dalam kehidupan seseorang. Cendekiawan Muslim, Anis Malik Thoha, dalam buku Tren Pluralisme Agama: Tinjauan Kritis, mengatakan: "Kata "Pluralisme", mempunyai tiga pengertian, yaitu: Pertama, pengertian kegerejaan: (i) sebutan untuk orang yang memegang lebih dari satu jabatan dalam struktur kegerejaan, (ii) memegang dua jabatan atau lebih secara bersamaan, baik bersifat kegerejaan maupun non kegerejaan. Kedua, pengertian filosofis; berarti sistem pemikiran yang mengakui adanya landasan pemikiran yang mendasarkan lebih dari satu. Sedangkan ketiga, pengertian sosiopolitis: adalah suatu system yang mengakui koeksistensi keragaman kelompok, baik yang bercorak ras, suku, aliran maupun partai dengan tetap menjunjung tinggi aspek-aspek perbedaan yang sangat kerakteristik di antara kelompok-kelompok tersebut. ${ }^{34}$

Pluralisme merupakan tema penting dan populer dalam berbagai kajian, khusunya berkaitan dengan studi teologi. Pluralisme akan selalu menjadi perbincangan yang terus mewacana khususnya di hadapan para akademisi selagi dunia ini masih dalam keadaan natural. Pluralisme adalah pandangan filosofis yang tidak mau mereduksi segala sesuatu pada satu prinsip terakhir, melainkan menerima adanya keragaman. ${ }^{35}$ Liza Wahyuninto dan Abd. Qadir Muslim dalam buku yang berjudul Memburu Akar Pluralisme Agama, menyatakan bahwa: Pluralisme berangkat dari postmoderanisme yang bercorak semrawut tetapi kreatif dan berwatak merelatifkan segala apapun untuk mencapai kebenaran inheren, sebuah kebenaran yang tidak hanya dimiliki persona sebagai "yang punya", tetapi mengakui bahwa entitas diluar dirinya memiliki hak yang sama untuk menggapai kebenaran, walaupun kebenaran yang dipersepskan entitas yang satu dengan yang lain sangat mungkin lain atau bahkan bertabrakan. ${ }^{36}$

Bagi Wahyuninto, pluralisme merupakan konsep yang menjadi cikal bakal

\footnotetext{
${ }^{34}$ Anis Malik Thoha, Tren Pluralisme Agama: Tinjauan Kritis, 11.

35 Gerald O'Collins dan Edward G. Farrugia, Kamus Alkitab, (Yogyakarta: Penerbit Kanisius), hlm. 257.

36 Liza Wahyuninto dan Abd. Qadir Muslim, Memburu Akar Pluralisme Agama. (Malang: Universitas Islam Negeri-Maliki Press: Malang. 2010), hlm. 1.
} 
munculnya post-modernisme, yang merupakan gambaran dunia modern dengan bentuk sikap dan perilaku manusia yang ada didalamnya. Tentunya dengan melihat hal-hal yang berhubungan dengan ciri khas yang terlihat dari kreatifitas, kesemerawutan dan relativisme. Lebih lanjut Wahyuninto berkata: "Pluralisme agama adalah upaya sadar untuk tidak sekedar menghormati pemeluk agama lain, tapi ikut pula bahu membahu bersama agama lain untuk membahas, bergerak membenahi bangsa, sosialkemasyarakatan, politik, kebudayaan hingga pada membela bangsa ketika terjadi intimidasi baik dari dalam negeri maupun luar negeri. Komunikasi semacam dialog antar umat beragama dianggap penting, untuk menghindari truth claim yang selama ini menjadi sesuatu yang merisaukan. ${ }^{37}$

Pemikiran pluralisme agama muncul pada masa yang disebut pencerahan atau Enlightment Eropa, tepatnya pada abad ke-18, dimana masa tersebut juga sering disebut sebagai titik permulaan bangkitnya gerakan pemikiran modern; yaitu masa yang diwarnai dengan wacana-wacana baru pergolakan pemikiran manusia yang berorientasi pada superioritas akal atau rasionalisme dan pembebasan akal dari kungkungankungkungan agama. Di tengah hiruk pikuk pergolakan pemikiran di Eropa yang timbul sebagai konsekuensi logis dari konflik-konflik yang terjadi antara gereja dan kehidupan nyata di luar gereja, muncullah suatu paham yang dikenal dengan nama liberalisme, yang komposisinya adalah kebebasan, toleransi, persamaan dan keragaman atau pluralisme. $^{38}$

\footnotetext{
${ }^{37}$ Ibdi, hlm. 6.

${ }^{38}$ Anis Malik Thoha, hlm. 16-17.
}

Sejarah mencatat bahwa pluralisme agama merupakan bagian tak terpisahkan dari spektrum sejarah lokal, politik, kultur serta sosio keagamaan yang terjadi dalam dinamika pemikiran masyarakat Eropa pada periode enlightment atau pencerahan pada abad ke-18. Pada masa itu terjadi suatu perubahan yang signifikan dalam kehidupan masyarakat Eropa dimana titik tolak perubahan yang mendasar terjadi pada aspek pemikiran manusia secara global. Pada masa itu, rasio menjadi hal yang paling dikagumi karena selama ini terbelenggu oleh doktrin gereja.

Dalam upaya membangun hubungan yang harmonis dan selaras dalam kehidupan bermasyarakat maka diperlukan suatu pola atau pedoman dalam upaya tersebut. Agama merupakan hal yang penting dan mendasar dalam kehidupan seseorang, dan kenyataan kemajemukan dalam hal agama tak dapat dihindarkan. Agama-agama yang ada memiliki pengikut dan telah membentuk sedemikain rupa wawasan dan cara berpikir seseorang sehingga beberapa diantaranya menjadi sedemikian fanatik. Inilah yang dianggap sebagai bibit perpecahan dalam kehidupan bermasyarakat. Upaya pluralisme dianggap beberapa orang sebagai hal yang baik untuk menjembatani berbagai perbedaan. Syaratnya adalah sikap untuk tidak memandang agamanya lebih benar dan lebih superior terhadap agama lain.

Abad ke-18 merupakan titik tolak perubahan fundamental dalam kehidupan umat manusia, dimana pada masa itu dalam sejarah pemikiran manusia secara global dianggap mengalami perubahan yang signifikan. Dalam kehidupan umat manusia pada waktu itu terjadi perubahan yang luar biasa dalam hal pola pikir manusia. Dominasi dan pemujaan terhadap akal pikiran manusia menjadi 
sesuatu yang lumrah karena upaya untuk melepaskan diri dari cengkraman dan belenggu dogmatika keagamaan, khususnya gereja yang terjadi berabad-abad lamanya. Upaya pembuktian secara eksperimental (scientific), menjadi kunci dari semuanya keputusan. Fakta sejarah tersebut merupakan konsekuensi logis atas perseteruan yang terjadi dimana gereja yang begitu otoriter dan absolut dengan kekuatannya menekan rasio yang dipaksa tunduk kepada dogmatika gereja.

Fakta bahwa perkembangan ilmu pengetahuan di Eropa yang sedemikian pesat tak bisa dihindari. Pada waktu itu banyak ilmuan yang mampu memberikan kontribusi ilmiah bagi peradaban umat manusia. Penemuan berbagai hal dan juga konsep berpikir terus terjadi dan dengan upaya melepaskan diri dari kungkungan doktrinal gereja telah melahirkan warna baru dalam pola pikir manusia, yaitu liberalisme. Hal yang tadinya dianggap mampu membebaskan manusia dari pemikiran yang tradisional ke arah yang lebih moderat dan dewasa; dikemudian hari menjadi bumerang yang mematikan, sebab agama akhirnya diabaikan.

\section{Humanisme}

Istilah humanisme, berasal dari kata Latin, humanitorum, yang berarti manusia atau kemanusiaan, namun jika dilihat dari segi kebahasaan; humanisme berasal dari kata Latin humanus dan mempunyai akar kata homo yang berarti manusia. Humanus berarti sifat manusiawi atau sesuai dengan kodrat manusia. $^{39}$ Jean Paul Sartre, (19051980), seorang filsuf Perancis, dalam buku Eksistensialisme dan Humanisme,

\footnotetext{
${ }^{39}$ Haryanto Al-Fandi, Desain Pembelajaran yang Demokratis \& Humanis, (Yogyakarta: Penerbit Ar-Ruzz Media, 2011), 71.
}

menyatakan bahwa: "Humanisme sebagai sebuah aliran filsafat yang bertolak dari faham antropomorfisme." ${ }^{40}$ Tokoh besar dari Humanisme adalah seorang yang bernama Desiderus Eramus (1469-1536), dari Rotterdam, yang bersahabat baik dengan tokoh reformasi gereja Martin Luther. (1483-1546).

Humanisme memberikan kesan kuat akan manusia sebagai pusat dan tidak menerima hakikat Tuhan adikodrati di atas manusia, gerakan ini pada prinsipnya merupakan kecenderungan untuk menggali potensi manusia, baik secara individu ataupun kelompok. Dalam konteks masa, maka humanisme dapat di bagi dalam beberapa waktu, yaitu:

Pertama, Humanisme Lama; dimana tokoh yang terkenal menganut paham ini adalah Eramus, yang juga sering disebut sebagai bapak Humanisme. Erasmus adalah seseorang yang sebetulnya terbuka dan menerima kebajikan manusia seperti yang diceritakan dalam Alkitab, dan menjadikan Yesus Kristus sebagai tokoh manusia yang ideal sehingga kemudian menolak beberapa hal yang dipandang ilahi, sifat dogmatis dan tekanan pada otoriter agama. Humanisme menjadi pilihan karena agama Kristen pada masa itu dianggap gagal dalam membangun peradaban manusia yang lebih bermoral dan bertanggung jawab.

Francis Bacon merupakan negarawan, filsuf dan ilmuan yang merintis jalan pada penyelidikan alam yang akurat walaupun ia tidak mau secara radikan melepaskan diri dari ajaran-ajaran agama tertentu. Thomas Hobbes (1588-1679) yang secara tuntas menerobos batas tersebut diatas dan kemudian mengembangkan filsafat ilmu

40 Jean Paul Sartre, Eksistensialisme dan Humanisme, terj. Yudhi Murtanto, (Yogyakarta: Pustaka Pelajar, 2002), 103. 
pengetahuan yang materialistis, yang melepaskan diri dari agama Kristen, yang kemudian diteruskan oleh pemikir lainnya seperti Rene Descrates (1596-1650) yang dikenal sebagai bapak rasionalisme, dimana dengan akal budinya sebagai pusat ilmu pengetahuan semesta.

Humanisme terus mengalami perkembangan dengan memberikan pengaruh kepada pemikiran dan peradab umat manusia kala itu yang kemudian disusul dengan munculnya aliran-aliran pemikiran pada abad-abad berikutnya dalam bentuk Humanisme Rasional, seperti Positivisme dan Pencerahan, dan yang mempunyai konotasi mirip dalam bentuk paham Humanisme Evolusi atau Humanisme Naturalis, seperti yang dipelopori oleh Julian Huxley (18871975). Descrates menonjolkan akal budi sebagai pusat kemampuan manusia, sedang Frederich Nietsche (1844-1900) dan Aguste Comte (1798-1857), tokoh Neo-Positivisme yang mempopulerkan Agama Humanisme, dimana Tuhan diturunkan dari tahkta-Nya dan manusia ditempatkan sebagai pusat. Dari paham humanisme inilah yang memulai suatu sikap bahwa manusia harus mencari jalan hidupnya sendiri, dan banyak orang humanis akhirnya menjadi ateis.

Kedua, Humanisme sekuler yang menyuarakan gerakan budaya dan intelektual, yang pada prinsipnya ingin menjelaskan keberadaan manusia tanpa ada sangkut pautnya dengan Tuhan.

Pada prinsipnya Humanisme Sekuler merupakan paham budaya dan pemikiran mengenai hidup yang didasarkan sikap menolak Tuhan dan halhal yang bersifat adikodrati, dan menggantikannya dengan diri sendiri (self), ilmu pengetahuan (science), dan kemajuan (progress); dimana pandangannya antara lain bahwa: Tidak ada Allah yang bisa menyelamatkan manusia.
Manusia harus menyelamatkan dirinya sendiri! Akal budi dan kepandaian adalah alat yang paling ampuh yang dimiliki oleh umat manusia. ${ }^{41}$ Pandangan Humanisme Sekuler dapat dilihat dari ucapan-ucapan para tokohnya yang dimuat dalam majalah Humanist di Amerika serikat, seperti yang diucapkan oleh Kurt Vonnegut (1922-2007). Berdasarkan pandangan Humanis tersebut, persoalan umat manusia seperti aborsi, kumpul kebo, membunuh, ketidakadilan, kejahatan dan penyimpangan-penyimpangan etis lain-nya dianggap sebagai urusan kemutlakan di luar dirinya, baik itu berupa ajaran agama maupun peraturan-peraturan sosial. ${ }^{42}$

Ketiga, Humanisme Kosmis. Perlu diketahui bahwa humanism sekuler yang semakin populer, telah berkembang menjadi sebuah gerakan baru yang disebut sebagai Gerakan Zaman Baru dalam banyak bentuk. Gerakan itu juga dikenal sebagai Humanisme Kosmis atau Humanisme Baru. Pada prinsip-nya, Humanisme Kosmis itu berlawanan dengan praktik-praktik yang rasional dan materialistis sebab di didalamnya ditekankan pengalaman-pengalaman kemanusiaan yang bersifat mistis dan kosmis. $^{43}$ Hal itu sangat menarik manusia karena menawarkan hal-hal yang tidak dapat dipenuhi oleh Rasionalisme dan Materialisme yang mendominasi dunia teknologi masa modern saat ini.

Dalam Humanisme Lama sampai Humanisme Baru, dengan gampang ditemukan hal pemberontakan manusia terhadap Tuhan dimana manusia ingin membebaskan dirinya dari kuasa di atas dirinya. Humanisme Kosmis, khususnya, mempunyai kesamaan erat dengan

\footnotetext{
${ }^{41}$ Daniel H. Wirawan, Mengenal Universalisme Kristen, hlm. 33

${ }^{42}$ Ibid, hlm. 34.

${ }^{43}$ Ibid, hlm. 36.
} 
Humanisme Sekuler karena keduanya mengakui bahwa hanya ada satu realitas dalam alam semesta ini, atau yang dikenal sebagai monisme. ${ }^{44}$ Diskusi mengenai humanisme tidak bisa dilepaskan dari pemikiran dunia Barat, dimana gerakan ini muncul sebagai akibat adanya gerakan renaissance di Eropa. Gerakan yang mencari penafsiran baru tentang manusia dalam kehidupan dunia ini terus berkembang. Pada awal kemunculannya, humanisme merupakan gerakan filsafat dan sastra di Italia pada pertengahan abad ke-14 yang kemudian menyebar ke negara-negara lain di Eropa sebagai ciri khas modernitas kawasan tersebut.

Humanisme muncul karena adanya rasionalisme sehingga melahirkan Renaisans, yaitu gerakan kebangunankembali manusia dari keterkungkungan mitologi dan dogmatika. ${ }^{45}$ Namun demikian, Rene Descartes yang dikenal sebagai bapak pendiri filsafat modern memandang rasionalisme tidak boleh mengingkari eksistensi Tuhan sebagai ide tentang ada yang paling sempurna. ${ }^{46}$ Humanisme yang hanya didasar-kan pada

\footnotetext{
44 Lihat penjelasan Daniel H. Wirawan dalam buku Mengenal Universalisme Kristen, (hlm. 4546) menyatakan bahwa Monisme atau Monism berasal dari kata Yunani yaitu monos yang berarti sendiri, tunggal dimana istilah monisme menunjuk kepada suatu paham yang berpendapat bahwa unsur pokok dari segala sesuatu adalah unsur yang bersifat tunggal atau esa. Unsur tersebut bisa berupa materi, pikiran, Allah, energi dll. Bagi kaum materialis unsur itu adalah materi, dan ini berbeda dengan kaum idealis yang memandang unsur itu adalah roh atau ide. Christian Wolff (1679-1754) merupakan orang pertama yang menggunakan terminologi monisme.

${ }^{45}$ Syari'ati Ali, Humanisme: antara Islam dan Mazhab Barat, terj. Afif Muhammad, cet. 2, (Bandung: Pustaka Hidayah, 1996), hlm. 42.

46 Roger Scruton, Sejarah Singkat Filsafat Modern: dari Descartes sampai Wittgenstein, terj. Zainal Arifin Tandjung, (Jakarta: Pantja Simpati, 1984), hlm. 31, 37.
}

pemikiran akal sesungguhnya tidak mampu mewujudkan jati diri manusia yang sesungguhnya. Hal itu terbukti dalam perjalanan sejarah peradaban umat manusia.

Kaum humanis memandang bahwa penekanan kepada ilmu logika dan ilmuilmu teoritis seperti ilmu metafisik sebagai sikap yang kurang patut. Mereka hanya berminat kepada kepada bidangbidang yang berfungsi langsung dalam kehidupan masyarakat, seperti retorika dan cabang-cabangnya ter-masuk politik, sejarah, dan syair. Selain itu, mereka juga tertarik kepada bidang dialektika atau seni dialog. Secara lebih umum, kaum humanis terikat kepada pemikiran mengenai kedudukan dan potensi manusia di dunia tanpa mempertimbangkan hakekat manusia sebagai mahluk yang dicipta Tuhan dengan batasan kemanusiaannya.

Sebagaimana disebutkan di atas bahwa pada mulanya humanisme merupakan sebuah gerakan dengan tujuan untuk mem-promosikan harkat dan martabat manusia, namun dalam perkembangan selanjutnya, humanisme berupaya menempatkan manusia sebagai yang tertinggi dalam penentuan sikap dengan otoritas kemanusiaannya. Itulah sebabnya kaum humanis terjebak pada eksistensi kemanusiaannya yang dalam dan mereka lupa akan kodrat sebagai mahluk yang dicipta. Pemikiran yang dihasilkannya di-anggap sebagai sesuai yang paling baik, sempurna dan tanpa salah. ${ }^{47}$

Dari pijakan tersebut di atas, nampak terlihat dengan jelas bahwa teologi religionum merupakan upaya manusia untuk mengatasi permasalahan kemajemukan keyakinan didalam kehidupannya. Dengan mengandalkan

${ }^{47}$ Daniel H. Wirawan, hlm. 47 
logika, perasaan dan hitungan lainnya; manusia menganggap dirinya mampu untuk mengatasi berbagai permasalahan yang kompleks dalam kehidupan multi agama.

Humanisme sebagai suatu gerakan intelektual yang pada prinsipnya merupakan aspek dasar dari gerakan Renaissance, dimana tujuan gerakan tersebut adalah untuk melepaskan diri dari belenggu kekuasaan gereja dan membebaskan akal budi dari kungkungannya yang mengikat. Maka dalam batasan-batasan tertentu, segala bentuk ke-kuatan dari luar yang membelenggu kebebasan manusia harus segera dipatahkan.

Kebebasan merupakan tema terpenting dari humanisme, tetapi bukan kebebasan yang absolut, atau kebebasan yang hanya sebagai antitesis dari diterminisme abad pertengahan yang dilakukan oleh gereja pada waktu itu, tapi bukan berarti humanisme pada waktu itu menentang tentang adanya kekuasaan Tuhan. Namun, mereka percaya bahwa di balik kekuasaan Tuhan, masih banyak peluang bagi manusia untuk menentukan jalan hidupnya, mengembangkan potensi dan memilih masa depannya sendiri, tanpa terbelenggu oleh kodrat atau ketakutan terhadap murka Tuhan. Dalam perkembangannya humanisme pada akhirnya mengesampingkan Tuhan karena mengedepankan aspek humanitas dalam diri manusia.

\section{Teologi Liberal}

Owen Chadwick dalam buku The Secularization of the European Mind in the Nineteenth Century, menyatakan bahwa kata liberal secara harfiah artinya bebas (free), yang artinya bebas dari berbagai batasan (free from restraint). ${ }^{48}$ Kekristenan Eropa mengalami permasalahan besar sehingga identifikasi diri menjadi masalah bagi gereja kala itu. Akhirnya mereka terpengaruh oleh perkembangan filsafat dan ilmu pengetahuan yang berkembang cukup pesat di Eropa.

Zaman Renaissance berlangsung pada akhir abad ke-15 dan 16 bukan saja mem-berikan pengaruh pada dunia sastra dan musik, melainkan ada suatu kegairahan untuk ilmu pengetahuan. Beberapa tokoh lahir dengan karya dan pemikiran yang luar biasa, seperti: Leonardo da Vinci (1452-1519), Nicolaus Copernicus (1473-1543), Johannes Kepler (1571-1630), Galileo Galilei (1564-1643), dan lainnya. Renaissance kemudian dilanjutkan dengan The age of Reason pada abad ke-17 dan kemudian The age of enlightenment pada abad ke18. Karya besar Galileo Galilei kemudian diteruskan oleh Isaac Newton (1642-1727) yang mengembangkan fisika klasik. Kemudian kajian ilmu filsafat dikembangkan oleh Francis Bacon (15611623), Rene Descartes (1596-1650), Baruch de Spinoza (1632-1677), G.W. Leibnitz (1646-1716), Blaise Pascal (1633-1662), G. Berkeley (1665-1753), David Hume (1711-1776), Imanuel Kant (1724-1804), dan sebagainya.

Bernard Lewis dalam buku What Went Wrong?: Western Impact and Middle Eastern Response mengatakan: "Sejarah kekristenan banyak diwarnai dengan perpecahan (skisma) dan kekafiran (heresy), dan dengan konflik antar kelompok yang berujung pada peperangan atau persekusi. Sejarah bermula sejak zaman Konstantine, dimana terjadi konflik antara Gereja

\footnotetext{
${ }^{48}$ Owen. Chadwick, The Secularization of the European Mind in the Nineteenth Century, (New York: Cambridge University Press, 1975), p. 210.
} 
Konstantinopel, Antiokia, dan Alexandria. Lalu, antara Konstantinopel dan Roma, juga antara Katolik dan Protestan dan antara berbagai sekte dalam agama Kristen itu sendiri. Setelah banyak konflik berdarah terjadi, maka muncul dari kalangan Kristen sendiri yang berpikir, bahwa kehidupan toleran antar kelompok masyarakat hanya mungkin dilakukan jika kekuasaan Gereja untuk mengatur politik negara kala itu dihilangkan, begitu juga campur tangan negara terhadap Gereja. ${ }^{49}$ Apa yang dialami gereja kala itu merupakan sesuatu yang sangat pahit. Gereja berhadapan dengan konflik yang seringkali membawanya kepada pergumulan yang sungguh sulit.

Perkembangan yang luar biasa pesatnya dalam seluruh bidang ilmu pengetahuan itu nyatanya memberikan dampak besar bagi kekristenan. Salah satu hal yang nyata dalam teologi Kristen adalah munculnya warna teologi baru yang kemudian memberi pengaruh besar bagi arah pemikiran teologi Kristen hingga kini. Para teolog masa itu turut terpengaruh dengan kajian filsafat dan ilmu pengetahuan yang berkembang luar biasa. Pemikiran teologi Liberal mulai muncul pada abad ke-16, setelah reformasi, terus berkembang dan mendapat angin dengan perkembangan tersebut. Tony Lane, dalam buku Runtut Pijar, mengatakan: "Liberalisme adalah pangkal penyesuaian yang mendasar dari teologi Kristen dengan dunia modern. Kaum liberal bersedia melepaskan banyak unsur-unsur tradisional ortodoksi Kristen dalam usaha mereka mencari makna bagi zaman kini."

49 Bernard Lewis, What Went Wrong?: Western Impact and Middle Eastern Response, (London: Phoenix, 2002), p. 231.

50 Tony Lane, Runtut Pijar, (Jakarta: BPK. Gunung Mulia, 1996), hlm. 196.
Friedrich Schleiermacher (17681834) merupakan salah satu tokoh penting yang lebih menekankan perasaan dan pengalaman dalam upaya memahami kebenaran doktrin Kristen. Itulah sebabnya beberapa esensial dalam kekristenan menjadi terabaikan. Louis Berkhof menyatakan bahwa Schleiermacher adalah bapak teologi modern yang hampir tidak menyebutkan iman yang menyelamatkan dan sama sekali tidak tahu apa-apa mengenai iman sebagai kepercayaan seperti seorang anak kecil kepada Tuhan. Ia mengatakan bahwa iman bukan apaapa kecuali pengalaman permulaan dari kepuasan akan kebutuhan spiritual kita oleh Kristus. ${ }^{51}$ Bahkan pandangan Schleiermacher bersama Albrecht Ritschl (1822-1889) menandai sesuatu yang besar dalam teologi liberal modern.

Dalam teologi liberal iman bukanlah suatu pengalaman surgawi, tetapi merupakan pemerolehan manusia; bukan sekedar menerima anugerah yang diberikan, tetapi suatu tindakan atas manusia sendiri; bukan penerimaan terhadap doktrin, tetapi membuat Kristus menjadi Tuhan dalam satu usaha untuk membentuk hidup seseorang menurut contoh Kristus. ${ }^{52}$ Dengan demikian, dalam pemikiran tokoh teologi liberal ini, Yesus Kristus hanyalah sebagai guru, teladan, atau contoh; bukan sebagai Tuhan dan penebus dosa umat manusia.

Albrecht Ritschl

(1822-2889) menekankan aspek etika dan praktika, dan pengajarannya itulah yang akhirnya mendorong timbulnya Injil sosial. Ritschl melihat doktrin Kristen dan memberikan argumentasinya dengan menolak dosa asal, inkarnasi, keilahian, penebusan, dan kebangkitan Kristus.

51 Louis Berkhof, Teologi Sistematika Jilid 4: Doktrin Keselamatan, (Jakarta: Lembaga Reformed Injili Indonesia, 1997), hlm. 189.

${ }^{52}$ Ibid, hlm. 189-190. 
Ritschl menganggap bahwa konsep dosa dan penyelamatan lebih serius dari pada Schleieermacher, namun belum juga memadai. Ia menolak doktrin dosa warisan dan menandaskan bahwa orang dapat hidup tanpa dosa. Tidak ada murka Allah terhadap dosa, dan pendamaian yang dibawa Yesus sebenarnya hanyalah perubahan sikap manusia. ${ }^{53}$ Terlihat dengan jelas bagaimana pandangan hamartiologi Ritschl dalam keyakinan teologinya tersebut. Selanjutnya Ritschl memandang enteng pribadi Yesus, sama seperti Schleiermacher yang hanya bisa berbicara tentang keilahian Yesus tetapi sesungguhnya maksudnya adalah kemanusiaan Yesus yang sempurna. Yesus adalah Allah dalam arti bahwa Ia mempunyai pengetahuan yang sempurna tentang Allah dan dipersatu-kan dengan Dia oleh ketaatan moral. ${ }^{54}$ Dalam pemahaman para teolog liberal tersebut, Yesus Kristus sedikit lebih tinggi dari manusia, namun lebih rendah dari Allah; posisi ini memungkinkan terjadi karena konsep kelahiran Yesus yang bersifat ilahi dibantah.

Adolf von Harnack (1851-1930) mengajarkan bahwa Paulus telah mencemarkan pengajaran Yesus Kristus dan kekristenan. Bersama dengan Ritschl, ia berpendapat bahwa bahwa Injil telah dirusak karena pengaruh filsafat Yunani. Harnack mencoba menelusuri proses peng-Yunani-an atau helenisasi tersebut. Agama sederhana yang dianut Yesus itu telah diubah, khususnya oleh Rasul Paulus, sebagai agama tentang Yesus. Konsep ini pada gilirannya berubah menjadi dogma penjelmaan Allah Anak. Mulanya liberalisme tidak diminati orang dan hal itu berlansung cukup lama, namun sekarang ia mulai muncul kembali

\footnotetext{
${ }^{53}$ Ibid.

${ }^{54}$ Tony Lane, Runtut Pijar, hlm. 201-202.
}

sebagai suatu terbitan baru yang populer, dimana The Myth of God Incarnate atau Mite Allah yang menjelma; merupakan usaha untuk merehabilitasi pandangan Liberal lama mengenai Yesus Kristus. ${ }^{55}$

Dengan semangat keoptimisannya kaum Liberalis telah menetapkan untuk mendatangkan kerajaan Allah melalui usaha manusia itu sendiri. Itulah sebabnya dengan demikian Injil Sosial menjadi sentral pemberitaan mereka; diharapkan akan mewujudkan keadaan dunia yang lebih baik dan beradab. Bagi kelompok Liberal, Kerajaan Allah bukan berkaitan dengan masa yang akan datang, masa supranatural, tetapi sudah ada di sini dan sekarang melalui penerapan prinsip-prinsip dan etika Yesus Kristus.

Upaya untuk memberikan penjelasan mengenai dokmatika Kristen dalam pemikiran yang logis dengan mengandalkan pola pikir manusia, setidaknya hal tersebut menjadi katalisator lahirnya gerakan teologi religionum. Kaum liberal telah menjadi penyumbang yang cukup signifikan melalui karya para tokohnya, untuk melahirkan dan bahkan mendasarkan gerakan teologi religionum.

\section{Gerakan Oikumene}

Istilah Oikumene pada umumnya dipahami secara terbatas yaitu sebagai suatu istilah yang dipakai untuk perkumpulan lintas gereja melalui kegiatankegiatan atau ibadah bersama, tanpa menekankan tata cara peribadatan atau liturgi dan doktrin gereja tertentu, padahal jika disimak lebih mendalam sesungguh lebih dari sekedar itu. Isitilah Oikumene berasal dari bahasa Yunani yaitu Oikos yang berarti rumah dan Monos yang berarti satu. Yang dimaksud

${ }^{55}$ Ibid, hlm. 202-204. 
rumah dalam pengertian tersebut adalah dunia ini, sehingga kata oikumene menunjuk kepada dunia yang didiami oleh seluruh umat manusia.

Ch. Abineno, Oikumene dan Gerakan Oikumene menyatakan bahwa: "Oikumene berasal dari kata Yunani yang mengandung arti dunia yang didiami." 56 Dan Gerakan Oikumene dikerjakan sebagai salah satu wujud yang Alkitabiah untuk menuju pada keesaan Gereja. Gerakan Oikumene ialah gerakan yang bukan saja berusaha untuk menghubungkan atau mempersatukan kembali gereja-gereja Tuhan yang terpecah-pecah pada waktu itu, tetapi yang juga membantu gereja-gereja yang terpecah-pecah itu untuk menampakkan kesatuan mereka dalam hidup dan pelayanan mereka agar kesaksian mereka dapat dipercaya orang. ${ }^{57}$ Dengan demikian maka Gerakan Okumene merupakan salah satu wadah untuk menyatukan Gereja-gereja.

Christian De Jonge dalam buku, Menuju Keesaan Gereja: Sejarah, Dokumen-dokumen dan Tema-tema Gerakan Oikoumene, mengatakan: "Oikoumene adalah kata dari bahasa Yunani, yaitu Partitium Preasentis passivum femium dari kata kerja oikeo, yang berarti tinggal, berdiam atau yang mendiami. Oleh karena itu arti harfiah kata Oikoumene adalah "yang didiami". Tetapi particium ini telah mempunyai arti khusus sebagai kata benda. Arti pertama adalah geografis, dunia yang didiami (lih. Lukas $4: 5$, Roma $10: 18$, Ibrani $1: 6$ dan lain-lain). Kata Oikoumene juga mendapat arti politik: kekaisaran Romawi (lih. Kisah Para Rasul 24 : 5) dan semua penduduknya (lih. Kisah Para Rasul 17 :

56 J.L. Ch. Abineno, Oikumene dan Gerakan Oikumene, (Jakarta: BPK Gunung Mulia,1984), hlm. 7.

${ }^{57}$ Ibid, hlm. 10 .
6). ${ }^{58}$ Selanjutnya George B. Grose dan Bejamin J. Hubbard dalam buku Tiga Agama Satu Tuhan: Sebuah Dialog, berpendapat bahwa: "Oikoumene sesungguhnya merupakan istilah untuk menggambarkan kekristenan, gerakan Oikoumene untuk mendiami bumi yang kepadanya Injil diberitakan. Itu semacam para frase bagian akhir Injil Matius, untuk pergi dari membabtis bangsabangsa (Matius 28:18-20) atau bagian pembuka kisah para rasul, kamu akan menjadi saksiku ...sampai ke ujung bumi (Kisah Para Rasul 1 : 8). ${ }^{59}$ Tentunya pemahaman Grose dan Hubbard tersebut diatas, disampaikan karena kesatuan antar umat Tuhan menjadi sangat penting dalam upaya melaksanakan tugas dan fungsi gereja; khususnya berkaitan dengan pekabaran Injil. Jika ada kesatuan, maka akan lebih mudah untuk mengerjakan misi Kristus bagi dunia.

Sejarah mencatat bahwa gerakan Oikumene di Indonesia berawal dari pembentukan Dewan Gereja-Gereja di Indonesia (DGI) pada tanggal $25 \mathrm{Mei}$ 1950 di Jakarta dalam Konperensi Pembentukan DGI tanggal 22-28 Mei 1950 di Jakarta. DGI yang kemudian berganti nama menjadi Persekutuan Gereja-Gereja di Indonesia (PGI) sejak Sidang Raya DGI di Ambon (1984). Pergantian istilah dari Dewan menjadi Persekutuan; karena para pemimpin gereja waktu itu memandang bahwa kata persekutuan lebih mencerminkan kesatuan lahir batin, lebih mendalam, lebih bersifat gerejawi daripada penggunaan

\footnotetext{
${ }^{58}$ Christian De Jonge, Menuju Keesaan Gereja: Sejarah, Dokumen-dokumen dan Tema-tema Gerakan Oikoumene, (Jakarta: BPK Gunung Mulia, 2000), hlm. Xvii.

59 Geogre B. Grose dan Benjamin J. Hubbard (ed.), Tiga Agama Satu Tuhan : Sebuah Dialog, Terj. Santi Indra Astuti, (Bandung: Mizan, 1998), hlm. 227
} 
kata dewan. Pembentukan organisasi yang didalamnya berkumpul sejumlah gereja yang cukup besar ini bertujuan untuk mewujudkan gereja Kristen yang satu di Indonesia.

Signifikansi gerakan Oikumene di Indonesia karena melihat keadaan gerejagereja yang sering diwarnai pertikaian dan perpecahan. Haruslah diakui bahwa persoalan perbedaan pandangan doktrinal dan ambisi memiliki andil dalam perpecahan tersebut. Munculnya banyak denominasi saat ini justru mengkotakkotakkan umat Tuhan di Indonesia, karena tidak jarang satu denominasi merasa lebih benar, lebih baik dan layak dibandingkan yang lain. Jadi masalah perpecahan pada akhirnya menjadi hal yang umum dijumpai dalam kehidpan bergereja di Indonesia. Itulah sebabnya gerakan Oikmene dipandang sebagai solusi dari kerumitan tersebut.

Persekutuan Gereja Indonesia (PGI) yang sejak awal berdirinya menjadi corong bagi upaya penyatuan gereja, melalui gerakan Oikumene di Indonesia; terlihat perannya. Gerakan Oikumene di Indonesia berjalan secara melembaga, melalui PGI dan telah dilakukan beberapa usaha untuk maksud tersebut. Salah satu bukti dari upaya pelaksanaan gerakan tersebut maka telah ditetapkan perayaan bulan Oikumene, dan untuk perayaan bulan Oikumene pada tahun 2013, organisasi PGI menyampaikan beberapa ajakan berikut ini: Pertama, Terusmenerus tanpa mengenal lelah makin memperkuat persekutuan di dalam wadah PGI dan sekaligus memperluas tekad kebersamaan dengan berbagai aliran dan denominasi untuk pada akhirnya mewujud dalam Gereja Kristen Yang Esa di Indonesia. Kedua, Terus berkomitmen, bertekad dan melakukan aksi dalam upaya mewujudkan perdamaian dan keadilan bagi keutuhan ciptaan. Gereja- gereja diminta untuk memberikan sumbangan-sumbangan nyata bagi kehidupan masyarakat yang penuh damai tanpa kekerasan, hidup dalam damai sejahtera dengan siapa saja tanpa memandang perbedaan yang ada. Ketiga, Tak jemu-jemu untuk menyuarakan keadilan, penegakan hukum dan keberpihakan kepada pelestarian alam. Keadilan bagi gereja haruslah meliputi perjuangan untuk keadilan ekonomi, hak asasi manusia dan keadilan lingkungan. Keempat, Berpartisipasi secara penuh dalam gerakan kebersamaan Celebration of Unity yang akan di-selenggarakan 1718 Mei 2013, sebagai komitmen bersama bagi keutuhan Tubuh Kristus di Indonesia. ${ }^{60}$ Dengan gerakan Oikumene diharapkan terjalin komunikasi dan interaksi diantara umat-umat Tuhan dan denominasi-denominasi dapat meninggalkan sikap isolasinya.

Demikianlah cita-cita dari gerakan Oikumene dalam kekristenan diharapkan, bahwa denominasi-denominasi secara bersama-sama membangun persekutuan yang kuat dalam satu kesatuan sebagai tubuh Kristus tanpa menonjolkan doktrin masing-masing.

Gereja yang telah terpisah-pisahkan oleh perjalanan sejarah yang terjadi dalam berbagai pola. Ada gereja yang terpisah karena konsep doktrin yang tidak sama dan dianggap menyimpang satu dengan lainnya, ada yang berpisah karena prinsip organisatoria, ada juga karena berkaitan dengan personal, dan seterusnya. Dan yang terkotak-kotakkan inilah yang diupayakan untuk disatukan dalam semangat Oikumene.

60 http://www.pgi.or.id/index.php/agendapgi/item/66-bulan-oikoumene-2013. Diakses pada hari Rabu, tanggal 12 Februari 2018, pukul 20.45 WIB. 
Norman Gulley, dalam buku Christ is Coming, melihat gerakan Oikumene sebagai sebuah usaha untuk penyatuan gereja-gereja yang telah terpisah. Ada upaya yang nyata dalam penyatuan gereja yang terpisah-pisah tersebut. Gulley mengatakan bahwa: "Pada tahun 1054 Gereja Katolik Orthodox di Timur memisahkan diri dari Katolik di Barat. Pada tahun 1517 Gereja Protestan memisahkan diri dari Gereja Katolik. Jadi panggilan kepada Oikumene adalah panggilan untuk bersatu kembali seperti pada abad yang keempat dahulu.",61

Pada tanggal 25 Mei 1995 Paus Yohanes Paulus II mengeluarkan sebuah dokumen yang dikenal sebagai: Encyclical on Ecumenism atau Ut Unum $\operatorname{Sint}^{62}$ dimana dalam dokumen tersebut terungkap dengan jelas bagaimana gereja Katolik berusaha keras untuk mengembalikan group yang memisah-kan diri dari padanya yaitu Gereja Katolik Orthodox di Timur dan juga Gereja Protestan. Sebagaimana diketahui bahwa dalam sejarah gereja telah terjadi beberapa perpecahan, dan yang paling menonjol adalah gerakan reformasi yang dicanangkan oleh Martin Luther. Sejujurnya perpecahan ini terjadi karena keterpaksaan sebab kaum Reformed

${ }^{61}$ Norman Gulley, Christ is Coming, (New York: Review and Herald Publishing Association, $\mathrm{tt}$ ), $\mathrm{p}$. 112.

62 Ut unum sint adalah istilah Latin yang berarti Itu mereka menjadi satu, adalah sebuah ensiklik yang dikeluarkan oleh Paus Yohanes Paulus II pada tanggal $25 \mathrm{Mei}$, 1995. Itu adalah salah satu dari 14 ensiklik dikeluarkan oleh Yohanes Paulus II. Ensilik ini berkaitan dengan hubungan antara Gereja Katolik dan Gereja Ortodoks serta komunitas gereja Kristen lainnya; dimana dalam dokumen ini menegaskan bahwa kesatuan kedua kelompok norang percaya tersebut adalah penting; juga upaya untuk membangun kembali hubungan dengan gereja-gereja Protestan. (lih. penjelasannya pada Wikipedia.org., tentang Ut Unum Sint). hanyalah kelompok yang mengupayakan penegakan kebenaran doktrinal gereja yang telah salah dipahami oleh gereja Katolik.

Sejarah mencatat bahwa sebelum Paus Yohanes Paulus II mengeluarkan Encyclical on Ecumenism atau Ut Unum Sint sebagaimana yang disebutkan diatas; beberapa tahun sebelumnya, tepatnya pada tanggal 25 Januari 1959, dimana Paus Yohanes XXIII telah menyerukan gerakan Oikumene dan mengadakan rapat khusus untuk hal itu dengan tujuan untuk memanggil kembali kelompok yang sudah memisahkan diri dari Gereja Katolik. Kembali Norman Gulley, menegaskan bahwa: "Dalam pertemuan Ecumenical Council pada tanggal 25 Januari 1959 itu telah dicanangkan apa saja yang dapat dilakukan untuk berusaha mencapai kembali kelompok-kelompok yang telah terpisah tersebut. Isi dari Ecumenical Council dikaji kembali dengan semangat mempersatukan dunia ini dan bukan hanya untuk persatuan dunia kekristenan saja. Pengertian tersebut datang dengan alasan bahwa hanya Gereja Katolik saja yang menjadi saluran rahmat dan keselamatan yang sudah ditunjuk oleh Allah. Jadi panggilan untuk bersatu ini adalah bersatu dalam satu gereja. $^{63}$ Selanjutnya pada tanggal 29 Maret 1994 ada 13 orang pemimpin dari Gereja Katolik dan Gereja Evangelikal berkumpul bersama-sama untuk menandatangani surat pernyataan bahwa Katolik dan Evangelical secara bersamasama dalam misi Kristen dan melupakan apa yang pernah terjadi pada masa yang lalu. ${ }^{64}$

Secara internasional, sejarah dari gerakan Oikumene tidak dapat dilepaskan dari penyelenggaraan Konferensi

\footnotetext{
${ }^{63}$ Norman Gulley, Christ is Coming, p. 114

${ }^{64}$ Ibid. p. 118.
} 
Pekabaran Injil Sedunia di Edinburgh pada tahun 1910. Konferensi yang diikuti oleh 1.335 utusan dan 17 orang wakil dari Asia; dan dianggap sebagai cikal bakal lahirnya gerakan Oikumene. Salah satu upaya untuk penyatuan gereja dalam gerakan Oikumene adalah me-redam doktrin yang dianggap peka dan rentan dengan perpecahan. Dengan upaya tersebut maka hal-hal yang lebih umum dan dapat diterima oleh semua aliran gereja, dianggap hal yang baik untuk dibicarakan.

Christian De Jonge dalam Menuju Keesaan Gereja: Sejarah, Dokumendokumen dan Tema-tema Gerakan Oikoumene, mengatakan: "Gagasan untuk mengadakan dialog dengan orangorang dari agama lain sebenarnya terdengar sejak permulaan gerakan Oikoumene pada konperensi pekabaran Injil di Edinburgh (1910) dan dapat didengar juga pada konperensi IMC di Yerussalem (1928) dan Tambaran (1938). Dialog pada waktu itu terutama dilihat sebagai usaha untuk mengambil yang paling baik dari semua agama. Pada Sidang Raya DGD di Evanston (1954), dalam laporan mengenai Evangelism muncul motif baru untuk mengadakan dialog. Dikatakan bahwa kebangkitan agama-agama lain dan ideologi-ideologi sesudah perang dunia ke II memaksa gereja untuk memikirkan cara-cara lain untuk mengkomunikasikan Injil. ${ }^{65}$

Jika gerakan Oikumene merupakan upaya penyatuan gereja-gereja, dengan meng-hilangkan topik doktrin yang rentan dengan perpecahan, maka teologi religionum dianggap gerakan dalam konteks eksternal, yaitu antar agama, dimana konsep esensial suatu agama dibatasi sedemikian rupa supaya dapat

${ }^{65}$ Christian De Jonge, Menuju Keesaan Gereja: Sejarah, Dokumen-dokumen dan Tema-tema Gerakan Oikoumene, hlm. 182-183 diterima oleh agama yang lain. Dengan demikian maka terciptalah keselarasan hidup bermasyarakat dalam kemajemukan keagaman yang ada.

Semangat oikumene yang berupaya mempersatukan gereja dari berbagai aliran dan keyakinan iman yang lebih spesifik itu terus diupayakan, dan kaitannya dengan teologi religionum terlihat dari semangat kesatuan ini. karena berkehendak untuk bersatu maka ada kesepakatan untuk meng-hilangkan hal-hal yang dapat menghalangi terwujudnya kesatuan itu. Jadi keperbedaan kayakinan menjadi hal penting untuk dijembatani dengan arif dan bijaksanan.

\section{Tipologi Tripolar}

Tipologi Tripolar merupakan sebuah istilah yang akrab dengan studi agama-agama, dan juga berkaitan dengan perkembangan teologi religionum. Tipologi Tripolar bermaksud memberikan penjelasan terperinci mengenai teologi religionum yang dimaksudkan tersebut. Tipologi yang dimaksudkan tersebut itu digunakan sebagai standar di dalam studi teologi agama-agama, dan hingga kini masih banyak dipakai dalam diskursus teologi agama-agama. Tipologi Tripolar digunakan untuk memetakan beragam pendekatan para teolog dan nonteolog Kristen mengenai relasi kekristenan dengan agama-agama lain. Pemetaan ini didasarkan pada kesamaan dan perbedaan cara pandang mereka terhadap agama-agama lain di luar Kristen.

Perlu diketahui bahwa Tipologi Tripolar sebagaimana disebutkan diatas dipopulerkan oleh Alan Race ${ }^{66}$ yang

\footnotetext{
66 Alan Race, adalah seorang teolog Gereja Anglikan yang menjabat sebagai Uskup Leicester dan sangat dikenal dalam studi mengenai theologi
} 
merupakan pribadi yang banyak terlibat dalam pemikiran teologi agama-agama. Dan sebagaimana yang sudah disebutkan dalam bagian pendahuluan tulisan ini, bahwa Race menjadi begitu terkenal karena kajian Tipologi Tripolarnya ${ }^{67}$, yaitu: Eksklusivisme, Inklusivisme dan Pluralisme.

Walaupun dalam bagian pendahuluan tulisan ini sudah sempat diuraikan sepintas tentang Tipologi Tripolar, namun penguraian yang lebih terperinci ada dalam bagian ini. Pemikiran Alan Race tentang Tipologi Tripolar telah memberikan warna baru bagi upaya pembahasan tentang teologi religionum yang saat ini sedang populer dibicarakan pada berbagai strata masyarakat. Adapun pemikiran Tipologi Tripolar yang disampailam Race, yang adalah sebagai berikut:

\section{Eksklusivisme}

Eksklusivisme dianggap memberikan pengaruh pada perkembangan teologi religionum, karena sesungguhnya beberapa ahli menyatakan ketidaksukaan mereka terhadap sikap ini. Eksklusivisme, yang dapat dipahami sebagai suatu paham yang memiliki kecenderungan untuk memisahkan diri dari masyarakat. Paul F. Knitter dalam

agama-agama. yang terkenal di dalam studi teologi agama-agama. Race sangat rajin berpartisipasi dalam berbagai pertemuan antar agama. Sebagai editor kepala di jurnal internasional Interreligious Insight: A Journal of Theology and Engagement.

67 Alan Race memperkenalkan istilah "Tipologi Tripolar" sebagai salah satu pendekatan yang digunakan dalam mempelajari teologi religionum. Hingga saat ini tipologi tripolar menjadi standar dalam studi teologi agamaagama. Tipologi tripolar digunakan untuk memetakan beragam pendekatan para teolog berkaitan dengan tanggapan kekristenan terhadap agama-agama lain. buku Satu Bumi Banyak Agama, model eksklusivisme ini dalam sejarah mewakili pandangan dominan umat Kristen yang memandang umat beragama lainnya yang tidak mengenal atau tidak tertarik kepada Kristen. ${ }^{68}$

Jika memahami pengertian dalam beberapa sumber maka istilah eksklusivisme sangat menarik untuk dikaji lebih mendalam lagi. Istilah eksklusivisme sangat dekat dengan kajian pluralisema agama, dan itulah sebabnya ia telah menjadi daya tarik tersendiri bagi sejumlah orang untuk menyelidikinya dengan lebih lanjut. Menurut Kamus Besar Bahasa Indonesia, kata Eksklusivisme berarti paham yang mempunyai kecenderungan untuk memisahkan diri dari masyarakat. ${ }^{69}$ Istilah eksklusivisme itu terdiri dari dua kata, yaitu: eksklusif, yang artinya terpisah dari yang lain atau yang khusus, dan kata isme, yang berarti paham. ${ }^{70}$ Dalam pemahaman sehari-hari, ekslusivisme dapat dipahami sebagai sebuah sikap yang memisahkan diri dan membentuk komunitasnya serta hidup didalamnya dengan konsep dan paham yang diyakininya.

Cedenkiawan Kristen yang menjadi tokoh penting dalam mempelopori gerakan teologi religionum di Indonesia, Th. Sumartana, dalam buku Dialog Kritik dan Identitas Agama berpendapat bahwa eksklusivisme merupakan suatu sikap me-nutup diri dari pengaruh agama lain, ingin mempertahankan keaslian dan

${ }^{68}$ Paul F. Knitter, Satu Bumi Banyak Agama; Diolog Multi-Agama dan Tanggung Jawab Global, terj. Nico A. Likumahua, (Jakarta: BPK. Gunung Mulia, 2008), hlm. 37.

69 Dendy Sugono (ed.), Kamus Bahasa Besar Indonesia, (Jakarta: Gramedia; 2008), hlm. 357.

70 Pusat Pembinaan dan Pengembangan Bahasa, Kamus Besar Bahasa Indonesia, (Jakarta: Balai Pustaka, 1999), hlm. 253 
kemurnian pribadinya. $^{71}$ Sikap yang demikian tentunya baik untuk kepentingan agamanya, sebab menjaga kemurnian suatu keyakinan sangatlah diperlukan, namun perlu juga sikap berhati-hati karena dapat menimbulkan suatu presenden buruk. Selanjutnya dalam buku Pluralisme dan Pruralisme, Th. Kobong me-ngatakan bahwa eksklusivisme merupakan suatu sikap yang arogan terhadap agama yang lain, yang membatasi kasih Allah yang tidak terbatas itu, mengurung Allah dalam sistem nilai-nilai yang dibuat oleh manusia itu sendiri. ${ }^{72}$

Jika memperhatikan beberapa uraian mengenai definisi istilah dari eksklusivisme, maka dapatlah disimpulkan bahwa sesungguhnya eksklusivisme itu merupakan suatu sikap yang menutup diri sebuah agama terhadap keyakinan atau agama lainnya. Artinya pemahaman bahwa agamanyalah yang paling benar dan terus berupaya mempertahankan konsep kebenarannya itu dengan menganggap diri paling benar dari pada agama atau keyakinan lainnya. Janganlah lupa bahwa sikap yang demikian akan menimbulkan perasaan fanatisme dan radikalisme yang berlebihan atas keyakinan agamanya. Dengan seperti itu maka akan sulit bagi mereka yang berpaham demikian untuk dapat membangun hubungan komunikasi, dialog dan bahkan kerja sama antar agama.

Dalam sudut pandang historika, sikap eksklusivisme sudah ada sejak zaman gereja mula-mula. Bahkan beberapa literatur membuktikan bahwa pandangan eksklusivisme berawal sejak gereja mula-mula yang ketika itu

71 Th. Sumartana, Dialog, Kritik dan Identitas Agama, (Jakarta: BPK. Gunung Mulia, 1996), hlm.78.

72 Th. Kobong, Pluralisme dan Pruralisme, (Jakarta: BPK. Gunung Mulia, 2003), hlm. 131 menganut paham teologi tradisional; dimana Perjanjian Baru ditafsirkan dalam terang panggilan untuk menerima Kristus sebagai penyataan Allah yang tertinggi dan absolut. Dalam pemahaman gereja pada umumnya; Yesus Kristus adalah Tuhan dan juruselamat umat manusia, dan inilah yang memang giat-giatnya diberitakan para rasul dan juga gereja masa kini.

Kaum eksklusivisme mendasari pemahamannya pada beberapa bagian Alkitab. Mereka melihat bagian-bagian itu sebagai hal yang perlu sampaikan. Itulah sebabnya pada saat Yesus Kristus berkata: "Akulah jalan dan kebenaran dan hidup. Tidak ada seorangpun yang datang kepada Bapa, kalau tidak melalui Aku. (Yohanes 14:6). Makna dibalik perkataan Tuhan tersebut sesungguhnya merupakan sebuah penolakan terhadap pemikrian universalisme, yaitu pandangan yang mengatakan bahwa pada akhirnya semua orang akan masuk surga; dan juga pandangan yang mengatakan bahwa orang yang beragama lain tetap bisa masuk surga sekalipun tidak percaya kepada Yesus Kristus. Pernyataan Yesus Kristus dalam bagian ini merupakan sebuah pernyataan yang dilontarkan tanpa perdebatan. Pernyataan Yesus Kristus tentang diriNya sebagai jalan merupakan sesuatu yang baik namun juga perlu diwaspadai.

Ketika rasul Petrus berkata bahwa: "Yesus adalah batu yang dibuang oleh tukang-tukang bangunan yaitu kamu sendiri, namun ia telah menjadi batu penjuru. Dan keselamatan tidak ada di dalam siapapun juga selain di dalam Dia, sebab di bawah kolong langit ini tidak ada nama lain yang diberikan kepada manusia yang olehnya kita dapat diselamatkan." (Kisah Para rasul 4:1112); maka yang patut diperhatikan adalah hal pernyataan: di bawah kolong langit 
ini tidak ada nama lain yang diberikan kepada manusia yang olehnya kita dapat diselamatkan. ... (ay. 12). Ada suatu pernyataan yang penuh keyakinan bahwa hanya Yesus Kristus-lah yang menjadi satu-satunya jalan keselamatan. Pernyataan bahwa Yesus adalah satu-satunya Tuhan dan juruselamat umat manusia inilah yang dipandang oleh agama lain sebagai sikap ekslusivisme Kristen dalam dogmatika soteriologis yang diyakininya.

Pernyataan berikutnya yang merupakan bagian yang peka dalam Alkitab sebagaimana disebutkan diatas, telah menempatkan kekristenan harus berhadapan muka dengan muka; harus bersinggungan dengan tajam dan bahkan keras, dengan agama-agama lain. Namun demikian, inilah kenyataan yang harus dihadapi. Beberapa orang dalam kekristenan pada akhirnya mencoba untuk memformulasi sebuah pengajaran mengenai soteriologi; tanpa menyinggung agama lain. Hal inilah yang dikemudian hari dikenal sebagai sebuah kompromi doktrinal yang pada akhirnya membuat doktrin Kristen terkoreksi.

Eksklusivisme telah mendapat perhatian para ahli untuk dilihat asas manfaatnya bagi usaha manusia untuk membangun hubungan yang selaras dan harmonis diantara pemeluk agama masing-masing. Menurut Paul F. Knitter, eksklusivisme dalam Kristen memandang umat beragama lain yang tidak mengenal atau tidak tertarik kepada Kristus sesungguhnya tidak memperoleh keselamatan. Mereka meyakini walaupun Allah adalah orang tua yang mengasihi dan merangkul semua anakNya, namun Ia sendiri telah memilih untuk melaksanakan karya penyelamatanNya, yaitu mereka yang mengaku dan merespon tawaran kasih ilahi, yang tersedia hanya melalui realitas historis Kristus dan melalui komunitas dimana berita dan kuasa keselamatan ada dalam Gereja Kristen. ${ }^{73}$ Lebih lanjut Knitter memberikan penjelasan dengan berkata bahwa: "Contoh model ini adalah evangelikal konservatif dan pentakosta yang bercorak eklesiosentris (terpusat pada Gereja) dengan model kristologis dimana Kristus bertentangan dengan agama-agama lain."74

Doktrin soteriologi yang menjadi pola pembeda antara kekristenan dengan agama-agama lain, pada akhrinya harus diabrasi sedemikian rupa guna mencocokan diri dengan keyakinan agama lain supaya dapat diterima secara universal. Itulah sebabnya formulasi murni doktrin soteriologi Kristen, oleh mereka yang hendak melakukan dialog dengan membangun jembatan komunikasi dengan agama lain dengan terpaksa harus dikebiri sedemikian rupa untuk mencari titik temu dan bahkan kesepakatan.

Dengan menyatakan Yesus Kristus sebagai satu-satunya juruselamat umat manusia maka sesungguhnya telah menutup pintu pada kemungkinan lain adanya juruselamat lain, selain Yesus Kristus itu sendiri. Karena itu gereja memberitakan keselamatan dalam Yesus Kristus dan menolak kebenaran di luar kekristenan, maka sikap eksklusivisme dalam agama Kristen tidak bisa dihindari. Walaupun sejumlah pengiat pluralisme menyatakan bahwa sikap eksklusivisme itu menjadi penghalang terjadinya komunikasi dan dialog antar agama, namun kenyataan yang tak terbantahkan dalam ajaran Kristen memang demikian halnya.

\footnotetext{
73 Paul F. Knitter, Satu Bumi Banyak Agama; Diolog Multi-Agama dan Tanggung Jawab Global, hlm. 37-38.

${ }^{74}$ Ibid, hlm. 35-36.
} 
Pada abad pertengahan, yaitu ketika itu reformasi gereja belum bergulir; dengan tegas gereja pada waktu itu memberikan pernyataan yang sangat tegas mengenai konsep soteriologinya. Paus Bonifasius VIII merumuskan suatu pandangan yang dikenal sebagai Extra Ecclesiam Nulla Salus atau diluar gereja tidak ada keselamatan. Pandangan Extra Ecclesiam Nulla Salus, dikukuhkan pada konsili Orange pada tahun 1442. Keyakinan Extra Ecclesiam Nulla Salus, menjadi sebuah kebenaran yang diyakini gereja. Andres Shank, dalam Civil Religion, Civil Society, mengutip pernyataan Hans Kung yang menyatakan bahwa: "Sumber eksklusivisme agama itu bisa dilihat dari rumusan yang dianggap suci oleh beberapa agama, seperti dalam Katolik Roma sebelum Konsili Vatikan II, yaitu Extra Ecclesian nulla salus, tidak ada keselamatan di luar gereja",75 pernyataan Kung tersebut sebenarnya memberikan kesan bahwa setiap agama memiliki paham yang eksklusifnya masing-masing.

Doktrin Extra Ecclesiam Nulla Salus, menjadi sebuah menara yang kuat bagi gereja dalam menyatakan eksistensinya sebagai satu-satu wadah untuk menemukan juruselamat, yaitu Yesus Kristus. Walaupun ada dugaan bahwa Konsili Vatikan II yang diselenggara-kan gereja Katolik; merupakan sebuah sarana yang dipakai untuk memberangus ajaran gereja tersebut, namun pada kenyataannya umat Kristen di seluruh dunia tetap pada jalur bahwa Yesus Kristus adalah Tuhan dan juruslemat dunia. Demikian juga dengan diskusi yang hangat dan bahkan perdebatan dikalangan Kristen mengenai pendekatan soteriologi. Apakah itu Universalsime Kristen,

75 Andres Shank, Civil Religion, Civil Society, (Oxford: Blackweel Publisher Ltd , 1999), hlm. 39.
Calvinisme dan Armenianisme; ketiganya berbeda dalam hal penekanan dan sudut pandang, namun satu pada konsepnya, yaitu Yesus Kristus adalah Tuhan dan Juruselamat umat manusia. Mengenai perdebatan ketiga poros tersebut akan dibahas secara khsusus dalam bagian selanjutnya disertasi ini.

Eksklusivisme merupakan gerakan misi abad 19 yang dipelopori oleh kelompok Reformed, demikian juga dengan kaum Evangelikal. Kelompok ini mendasari pe-mikiran eksklusivisme yang mereka yakini itu melalui keyakinan bahwa keselamatan tidak ada di dalam siapa pun juga selain di dalam Kristus sebab di bawah kolong langit ini tidak ada yang mampu memberi keselamatan maka muncullah istilah No Other Name yang menjadi simbol tentang tidak adanya keselamatan di luar Kristus. ${ }^{76}$

Dengan demikian pemikiran bahwa tidak ada keselamatan di luar Yesus menjadi absolut. Alkitab adalah kebenaran mutlak, diluar kekristenan tidak ada kebenaran mutlak dan tidak ada keselamatan. Jadi bagi penganut eksklusivisme, pengakuan terhadap kebenaran atau kuasa penyelamatan dari agama atau tokoh agama lain merupakan suatu tamparan terhadap muka Allah, suatu pencemaran terhadap apa yang telah dilakukan Allah dalam Yesus. Walaupun gereja-gereja eksklusif mau berdialog dengan umat lainnya, namun dialog semacam ini sering dimengerti hanya sebagai alat untuk membuat orang bertobat. $^{77}$

Kaum Injili sangat menekankan kemurnian akan agama Kristen, mereka tetap menerima berbagai perbedaan dalam agama-agama, namun tidak mem-

\footnotetext{
${ }^{76}$ Budhy Munawar dan Rahman, Islam Pluralis, (Jakarta: Raja Grafindo Persada, 2004), hlm. 5657

${ }^{77}$ Paul F. Knitter, hlm. 38
} 
buat kekristenan ter-gusur. Sikap kaum Evangelikal ini merupakan sesuatu yang baik untuk dijadikan teladan dalam membangun hubungan komunikasi antar agama-agama. Tony Lane dalam buku Runtut Pijar, berkata: "Kelompok Evangelikal atau Injili telah berusaha dengan lebih atau kurang menyesuaikan diri dengan dunia modern. Tetapi mereka menandaskan bahwa proses ini tidak boleh mengakibatkan oenyimpangan dalam Injil yang diberitakan Alkitab." Model Evangelikal Konservatif dengan yakin menjelaskan bahwa Agama Kristen adalah satu-satunya agama yang benar. ${ }^{79}$

Salah satu tokoh dari model Eksklusivisme ini adalah Karl Barth (1886-1968), dimana ia memutuskan bahwa semua manusia hanya dapat mengenal Yesus Kristus melalui wahyu dan satu-satunya wahyu adalah Yesus Kristus. Kristen adalah sebagai agama yang benar, wahyu dan keselamatan tidak ada dalam agama lain. Walaupun Barth sesungguhnya lebih dikenal sebagai tokoh aliran Neo-Ortodoks dalam kaitan pembahasan teologi kontemporer, namun ia sangat menekankan konsep bahwa hanya Yesus Kristus sebagai satu-satunya jalan keselamatan bagi umat manusia. tentunya pandangan Barth tidak diharapkan bagi kaum yang mengedepankan dialog dan kompromi dalam diskusi antar agama. Dalam hal ini menarik untuk memperhatikan Deklarasi Frankfurt ${ }^{80}$

78 Tony Lane, Runtut Pijar, (Jakarta: BPK. Gunung Mulia, 1996), hlm. 203.

${ }^{79}$ Paul F. Knitter, hlm. 35.

80 Sekumpulan orang Jerman yang tergabung dalam Dewan Gereja Sedunia menyelenggarakan Deklarasi Frankfurt pada tahun 1970 sebagai reaksi dari Sidang Raya Dewan Gereja Sedunia (WWC) di Uppsala pada tahun 1968 yang menghasilkan sesuatu yang dianggap merugikan kekristenan sebab dalam pertemuan tersebut dibahas mengenai dimensi "horizontal", yaitu perdamaian antar sesame dalam misi sehingga yang dinyatakan bahwa jika seseorang yang bukan Kristen meninggal tanpa pengetahuan tentang Yesus Kristus, maka mereka binasa. ${ }^{81}$

Yvonne Haddad \& Wadi Haddad, dalam buku Christian-Muslim Encounters, menyatakan bahwa: "Tidak semua muslim atau umat kristiani mengamini deklarasi tersebut. Pada tahun 1970, pertemuan evangelis diselenggarakan di Frankfurt, Jerman, dan menandatangani deklarasi yang disebut Deklarasi Frankfurt. Pertemuan ini berusaha menegaskan kembali misi Kristus, dan dengan keras mengkritik dialog yang diselenggarakan sebagai "pengkhianatan terhadap universalitas misi Kristus. ${ }^{82}$

Karl Barth menegaskan posisi teologis yang diyakininya atas agamaagama lain dengan mengatakan bahwa agama adalah bentuk ketidakpercayaan. Menurutnya, upaya manusia untuk mengenal Allah dari sudut pandangnya sendiri merupakan suatu upaya yang siasia, sehingga dapat dikatakan juga bahwa upaya ini menunjukkan suatu ketidakpercayaan. ${ }^{83}$ Pandangan Barth tersebut bertolak dari pandangan bahwa Yesus Kristus adalah kepenuhan wahyu Allah, dan didalam diri Yesus Kristrus, penyataan diri Allah kepada manusia menjadi lebih konkrit, absolut, dan definitif. Karena hal tersebut merupakan

dianggap mengabaikan aspek "vertikal”, yaitu Kristus dan manusia. Akibatnya penyelamatan dianggap manusiawi dan bersifat universal. Nilai soteriologi dalam Kristus menjadi berkurang. Pertemuan Upsala telah menimbulkan perdebatan yang hebat, dan deklarasi Frankfurt cenderung menolaknya. (lih. Tany Lane, Runtut Pijar, 1996, Hal. 262).

${ }^{81}$ Paul F. Knitter, No Other Name?, (New York: Orbis Books, 1985), p. 79.

${ }^{82}$ Yvonne Haddad and Wadi Haddad, ChristianMuslim Encounters, (Florida: University Press of Florida, 1995), p.xiii.

83 Joas Adiprasetya, Mencari Dasar Bersama, (Jakarta: BPK. Gunung Mulia, 2009), hlm. 51-52. 
satu-satunya perbedaan agama Kristen dan agama-agama lain ialah bahwa agama Kristen berdiri di tempat terang, sementara agama-agama lain dalam bayang-bayang. Bahkan Barth menganalogikan Kristus bagaikan matahari yang menerpa bumi, satu bagian terkena, yaitu agama Kristen dan bagian yang lain berada dalam bayang-bayang dan bahkan dalam kegelapan, yaitu agama-agama lainnya. Barth menegas-kan bahwa rahmat itu hanya dalam kaitannya dengan Yesus Kristus, rahmat bagi manusia mengalir dari Salib Kristus. Karena rahmat yang dianugerahkan kepada manusia tidak terlepas dari Kristus. Barth yakin, hanya dalam Yesus Kristus manusia mengalami Rahmat yang mendamaikan dirinya dengan Allah. ${ }^{84}$

Mengenai sikap dan pandangan Barth, dapatlah dikatakan bahwa ia berada dalam tradisi rasionalisme yang mengutamakan pendekatan a priori yang di mana terlalu berat sebelah memandang agama lain, bahkan cenderung bersikap tak adil kepada mereka. Dan tak dapat dihindarkan lagi bahwa pendekatan ini juga membuat Barth terkesan arogan dan tak adil terhadap umat beragama lain. ${ }^{85}$ Oleh orang yang setuju dengan teologi religionum, maka mereka melihat penekanan Barth yang amat negatif terhadap klaim ketidakpercayaan agamaagama dipandang amat berbahaya dan tidak adil sebab Barth penganut Eksklusivisme.

Sikap Eksklusivisme dipandang dapat mendatangkan hal yang tidak baik bagi upaya membangun jembatan dialog antar umat beragama. Sikap yang demikian dianggap tidak bijaksana. Supriatno dalam buku Merentang

84 E. Armada Riyanto, Dialog Interreligius, (Yogyakarta: Kanisius, 2010), hlm. 268-269.

85 Joas Adiprasetya, Mencari Dasar Bersama, hlm. 55 .
Sejarah Memaknai Kemandirian, mengatakan: "Bahaya Eksklusivisme adalah adanya potensi mendiskriminasikan sesama manusia lainnya. Ini terjadi ketika suatu agama hanya menganggap dirinya benar sendiri dan yang lainnya tidak, sehingga hubungan dengan sesama menjadi hubungan yang tidak setara. Sikap seperti ini pada gilirannya nanti akan menghasilkan hubungan yang bersifat diskriminatif dari satu terhadap yang lain. Akibatnya berbagai kekerasan yang bisa terjadi di mana atas nama Tuhan. ${ }^{86}$

Jika dikaitkan dengan agama, maka paham Eksklusivisme berarti suatu paham agama yang cenderung memisahkan diri dari masyarakat. Dalam artian mereka meng-anggap lebih Eksklusif dibanding dengan agama lain. Klaim ini tidak memberikan pilihan apapun terhadap suatu keyakinan dan memandang kebenaran suatu agama secara hitam putih, kebenaran agamanya sangat berbeda dengan negara lain. Dan masingmasing agama mengklaim agamanya sebagai yang paling benar. Pemikiranpemikiran yang radikal tentang agamalah yang mereka ajarkan.

Dengan demikian maka Eksklusivisme adalah suatu pandangan yang mengklaim bahwa hanya agama, bahkan alirannya yang benar dan satusatunya jalan menuju keselamatan. Agama lain dipandang sesat, tidak ada keselamatan darinya, dengan begitu ia berusaha untuk memasukkan penganut agama lain ke dalam apa yang dipahaminya.

\footnotetext{
86 Supriatno,Merentang Sejarah Memaknai Kemandirian, (Jakarta:BPK. Gunung Mulia, 2009), hlm. 159.
} 


\section{Inklusivisme}

Inklusivisme merupakan satu dari tiga tipologi yang dikemukakan Alan Race dalam diskursus teologi agamaagama, sebagaimana yang disebutkan dalam bagian sebelumnya. Ini merupakan sikap atau pandangan yang melihat bahwa agama-agama lain di luar kekristenan juga dikaruniai rahmat dari Allah dan bisa diselamatkan, namun pemenuhan keselamatan hanya ada di dalam Yesus Kristus. Kristus hadir dan bekerja juga di kalangan mereka yang mungkin tidak mengenal Kristus secara pribadi. Dalam pandangan ini, orangorang dari agama lain, melalui anugerah atau rahmat Kristus, diikutsertakan dalam rencana keselamatan Allah.

Liza Wahyuninto dan Abd. Qadir Muslim, dalam buku, Memburu Akar Pluralisme Agama, mengatakan bahwa: "Pandangan inklusivisme yang bertolak belakang dengan pandangan ekslusivisme. Menjadi inklusif berarti percaya bahwa ke-benaran tidak menjadi monopoli agama tertentu, tetapi juga ditemukan dalam agama-agama lain. "87 Lebih lanjut dikatakan bahwa ada juga pandangan Paralelisme yang ke-mudian dielaborasi menjadi pendukung teologi pluralime, berpandangan bahwa setiap agama secara paralel adalah sama. ${ }^{88}$ Disertasi ini tidak akan membahasnya lebih lanjut karena fokus kajian dari disertasi ini terletak pada aspek soteriologi. Bagi Wahyuninto, pandangan inklusivisme merupakan sebuah pandangan yang bertolakbelakang dengan pandangan ekslusivisme, dengan demikian maka pemahaman inklusivisme pasti berlawanan dengan ekslusivisme. Jika dalam ekslusivisme terjadi

${ }^{87}$ Liza Wahyuninto dan Abd. Qadir Muslim, Mem-buru Akar Pluralisme Agama. hlm. 63-64. ${ }^{88}$ Ibid. penolakan dan bahkan pengakuan akan adanya kebenaran dalam agama lainya, maka dalam pemahaman kaum inklusivisme justru melihat hal yang baik dalam agama-agama lainnya, sehingga secara umum dapat menerima hal yang baik tersebut.

Sejarah gereja mencatat bahwa penyelenggaraan dalam Konsili Vatikan II (1962-1965) ${ }^{89}$, yang cukup terkenal itu telah memberikan suatu hasil dimana terdapat dokumen Nostra Aetate ${ }^{90}$, yaitu deklarasi tentang sikap gereja Katolik terhadap agama-agama bukan Kristen. Dalam deklarasi tersebut menyatakan bahwa dalam agama-agama lain, ada usaha menanggapi kegelisahan hati manusia dengan pelbagai cara sambil

${ }^{89}$ Konsili Ekumenis Vatikan Kedua atau Vatikan II merupakan sebuah Konsili Ekumenis ke-21 dari Gereja Katolik Roma yang dibuka oleh Paus Yohanes XXIII pada 11 Oktober 1962 dan ditutup oleh Paus Paulus VI pada 8 Desember 1965. Dihadiri oleh 2540 orang uskup Gereja Katolik Roma sedunia, 29 pengamat dari 17 Gereja lain, dan para undangan yang bukan Katolik. Selama konsili, jumlah dokumen yang dihasilkan lebih banyak dan dampak pengaruhnya atas kehidupan Gereja Katolik lebih besar dari peristiwa manapun sesudah zaman reformasi pada abad XVI. Salah satu hal penting dalam konsili ini adalah berbicara tentang sikap gereja terhadap agama-agama lainnya, dan hal inilah yang dianggap sebagai sebuah rekomendasi untuk melihat agama lain setara dengan iman Kristen. (https://id.wikipedia. org/wiki/Konsili_Vatikan_II, diakses pada hari Rabu, tanggal 12 Desember 2013, pukul 21.35 WIB).

${ }^{90}$ Nostra Aetate adalah suatu dokumen Konsili Vatikan II yang berisi Pernyataan Tentang Hubungan Gereja Dengan Agama-Agama Bukan Kristiani. Berdasarkan dokumen inilah maka ara berpikir theologi dikalangan Katolik menjadi berubah. Jika tadinya gereja me-megang teguh adagium: "Extra Yesum Christum Nulla Salus" yang berarti "diluar Yesus Kristus tidak ada keselamatan"; kini mengalami degradasi yang fatal atas suatu penilaian dari iman Kristen. Jika tadinya Yesus merupakan satu-satunya juruselamat umat manusia, kini berubah ke arah kompromistik terhadap agama-agama. 
menganjurkan jalan, yakni ajaran (kultus), peraturan (etis), dan ibadat suci (ritus); dan gereja Katolik tidak menolak apapun yang benar dan suci dalam agama-agama, serta memandang dengan penghargaan yang jujur bahwa tidak jarang hal itu memantulkan cahaya kebenaran, yang menerangi semua manusia. Nostra Aetate yang merupakan dokumen penting yang dihasilkan dalam Konsili Vatikan II, merupakan salah satu bentuk dari gereja Katolik untuk memahami agama-agama di luar Kristen. Pernyataan Nostra Aetate diawali dengan penjelasan mengenai semakin eratnya penyatuan dan hubungan-hubungan antar bangsa dan antar pelbagai bangsa berkembang serta satu asal dan tujuan akhir dari semua bangsa, yakni Allah. ${ }^{91}$

Dokumen Nostra Aetate mengungkapkan juga mengenai pertanyaan abadi yang telah ada di dalam pemikiran manusia sejak awal mulanya dan bagaimana berbagai tradisi keagamaan yang beraneka ragam telah berupaya untuk menjawabnya. Ia menyatakan jawaban-jawaban filosofis Agama Hindu dan Budha. ${ }^{92}$ Sikap gereja Katolik yang akhirnya menerima keberadaan agamaagama lain dinyatakan dengan jelas dalam dokumen yang dihasilkan melalui persidangan Vatikan II. Lebih lanjut dinyatakan dengan jelas bagaimana gereja Katolik bersikap terhadap keyakinan iman agama-agama lainnya, yaitu: Gereja Katolik tidak menolak apa pun yang dalam agama-agama itu serba benar dan suci. Dengan sikap hormat yang tulus, Gereja merenungkan cara-cara bertindak dan hidup, kaidah-kaidah serta ajaranajaran yang memang dalam banyak hal berbeda dari apa yang diyakini dan

91 https://id.wikipedia.org/wiki/Nostra_Aetate, Diakses pada hari Senin, tanggal 16 Desember 2013, pukul 11.10 WIB.

92 Ibid. diajarkannya sendiri, tetapi tidak jarang toh memantulkan sinar kebenaran, yang menerangi semua orang. ${ }^{93}$ Selanjutnya dalam bagian ketiga melanjutkan dengan pandangan gereja Katolik yang menghargai umat Islam, dilanjutkan dengan meng-ungkapkan beberapa hal kesamaan antara Islam dengan Kristen dan Katolik yang menyembah Allah satu-satunya, Allah yang hidup dan berkuasa, Penuh belas kasihan dan mahakuasa, Pencipta langit dan bumi, Yang telah bersabda kepada manusia; para Muslim menghormati Abraham dan Maria, dan bahwa mereka menghormati Yesus sebagai nabi dan bukan Allah. Sinode mendorong seluruh kaum Kristiani dan Muslim untuk melupakan pertikaian dan permusuhan dari masa lalu dan bekerja sama untuk membela dan mengembangkan keadilan sosial bagi semua orang; nilai-nilai moral maupun perdamaian dan kebebasan. ${ }^{94}$

Dokumen itu juga berbicara mengenai adanya ikatan rohani antara umat Perjanjian Baru, yaitu Kristiani dengan umat Yahudi sebagai kaum Keturunan Abraham. Dokumen tersebut menyatakan bahwa meskipun beberapa pemuka agama Yahudi dan para pengikut mereka telah mendesakkan kematian Kristus, namun kesalahan ini tidak dapat serta merta dibebankan sebagai ke-salahan seluruh orang Yahudi; baik yang hidup ketika itu maupun sekarang. ${ }^{95}$ Selanjutnya Lebih lanjut Konsili menyatakan bahwa: "orang-orang Yahudi jangan digambarkan seolah-olah dibuang oleh Allah atau terkutuk". Pernyataan ini juga menentang segala unjuk-rasa antisemitisme yang dilakukan kapan pun dan oleh siapa pun. ${ }^{96}$

\footnotetext{
93 Ibid.

94 Ibid.

95 Ibid.

${ }^{96}$ Ibid.
} 
Dokumen Nostra Aetate atau dokumen yang menyatakan hal mengenai hubungan gereja dengan agama-agama yang bukan Kristen, merupakan salah satu dokumen Konsili Vatikan II yang kala itu disetujui oleh para Uskup dalam sebuah pemungutan suara dengan hasil 2.221 berbanding 88, dan diresmikan oleh Paus Paulus VI pada 28 Oktober 1965; selanjutnya menjelaskan bahwa seluruh menusia diciptakan menurut citra kesamaan Allah, dan Gereja mengecam segala diskriminasi antara orang-orang, atau penganiayaan berdasarkan keturunan atau warna kulit, kondisi hidup atau agama. $^{97}$ Gereja Katolik mencoba untuk memberikan ruang bagi keyakinan agama lain untuk berbanding lurus dan bahkan sejajar dengan keyakinan iman Kristen yang sebelumnya dipandang sangat eksklusive. Dari sinilah terkesan kuat bahwa gereja Katolik menjadi salah satu institusi yang mendukung berkembangnya gerakan teologi religionum.

Dengan menyatakan sikap kesejajaran keyakinan iman tersebut itulah maka terbukalah pintu yang sedemikian lebar untuk mendiskusikan hal-hal yang berkaitan dengan pluralisme. Walaupun dikemudian hari, Vatikan mengeluarkan Dekrit Dominus Jesus ${ }^{98}$ yang menjawab

\footnotetext{
97 Ibid.

98 Dominus Jesus adalah Deklarasi yang dikeluarkan oleh Kongregasi untuk Doktrin Iman (CDF) yang menjelaskan tentang keunikan dan ke-universal-an keselamatan di dalam Kristus dan Gereja Katolik. Kesimpulan Deklarasi Dominus Jesus ini berkata: bahwa satu-satunya Agama yang benar itu berada dalam Gereja katolik dan apostolik, yang oleh Tuhan Yesus diserahi tugas untuk menyebarluaskannya kepada semua orang, ketika bersabda kepada para Rasul: "Pergilah, jadikanlah semua bangsa murid-Ku dan baptislah mereka dalam nama Bapa dan Putera dan Roh Kudus, dan ajarlah mereka melakukan segala sesuatu yang telah Kuperintahkan kepadamu" (Matius 28:19-20). Adapun semua orang wajib mencari ke-benaran, terutama dalam apa yang
}

isu pluralisme; dimana dekrit yang dikeluarkan Paus Yohanes Paulus II pada tahun 2000 ini secara jelas menolak paham pluralisme agama. Namun demikian, kebanyakan kalangan Katolik mendukung gerakan teologi religionum.

Pakar Inklusivisme, Karl Rahner, menggabungkan suatu teologi yang bersifat Kristosentris dengan pengalaman keagamaan non-Kristen. Kristus tetap pusat dan kriteria dari anugerah dan penyelamatan Allah. Itulah sebanya orang-orang non-Kristen disebutnya sebagai orang Kristen Anonim. Pemahaman Rahner tersebut memberikan pintu bagi kajian teologi agama-agama. Rahner merumuskan pandangan teologinya mengenai agama-agama lain berdasarkan pendapat bahwa anugerah Allah ditawarkan kepada semua orang di seluruh dunia. Kalau Allah berkehendak demikian maka Ia pun bertindak demikian. $^{99}$ Gagasan tentang Kristen Anonim Rahner dikemukakan dalam empat pemikiran dasarnya, yaitu bahwa: Agama Kristen ditujukan untuk semua orang, sehingga agama lain tak diakui; Agama non-Kristen menjadi saluran anugerah Allah dalam Kristus, sebelum Injil memasuki sejarah individunya; Agama Kristen menghadapi agama lain sebagai Kristen Anonim; dan Orang Kristen sebagai barisan terdepan yang nyata dari harapan Kristen yang hadir sebagai realitas terselubung dalam agama-agama lain.

menyangkut Allah dan Gereja-Nya. Sesudah mereka mengenal kebenaran itu, mereka wajib mengamalkannya".(http://www.katolisitas.org/faq s/penjelasan-tentang deklarasi-dominus-iesus/ Diakses pada hari Senin, tanggal 17 Februari 2018, pukul 09.10 WIB.)

99 Soetarman, Weinata Sairin, dan Ioanes Rakhmat, Fundamentalisme, Agama-Agama Dan Teknologi, (Jakarta: BPK Gunung Mulia, 1996). hal 47-48. 
Keyakinan Alkitab bahwa hanya ada keselamatan dalam Kristus, tidak terbantahkan lagi namun gereja tidak boleh menentang agama-agama lain sebagai ajaran palsu dan tidak mempunyai keselamatan. Walaupun tidak sesempurna yang ada dalam gereja namun karena anugerah yang universal itu, maka keselamatan dalam Kristus pun ada di sana walaupun tidak memakai nama Kristus. Jadi dalam agama-agama lain, Kristus yang menyelamatkan itupun ada di sana tanpa bernama Kristus. Ini yang dinamakan Rahner sebagai Anonymous Christ atau Kristen Anonim atau Kristus tak bernama dan oleh sebab itu penganut agama-agama lain adalah sebenarnya juga orang-orang Kristen tanpa nama atau Anonymous Christian. ${ }^{100}$ Jadi Kristus tidak serta merta menjadi milik orang Kristen, sebab mereka yang bukan Kristenpun, jika hidup dalam kehidupan yang diisyaratkan agama Kristen, maka layak disebut sebagai orang Kristen yang bukan Kristen. selanjutnya Lesslie Newbigin, dalam buku, Injil dalam Masyarakat Majemuk, mengatakan bahwa: "Konsep Karl Rahner tentang Kristen-Anonim telah memberi pengaruh luas dan merupakan konsep inklusivisme Katolik. "Keselamatan melampaui batas-batas gereja yang kelihatan dan bukan saja individu-individu non-Kristen dapat diselamatkan, tetapi juga bahwa agamaagama bukan Kristen mempunyai peran menyelamat-kan."101

Berkaitan dengan konsep Anonymous Christian ini, Rahner memakai contoh perjumpaan Paulus dengan orang-orang Atena di mana ia berbicara tentang Allah yang tak dikenal (lih. Kisah

\footnotetext{
${ }^{100}$ Ibid.

101 Lesslie Newbigin, Injil Dalam Masyarakat Majemuk, (Jakarta: BPK Gunung Mulia, 2000), hlm. 244.
}

Para Rasul 17: 16-35). Joas Adiprasetya dalam buku Mencari Dasar Bersama: Etik Global Dalam Kajian Postmodernisme dan Pluralisme Agama mengatakan: "Raimundo Pannikar, yang berada dalam jalur inklusivisme yang sama dengan Rahner, namun yang mengkhususkan teologinya pada perjumpaan KristenHindu, mengatakan: Orang Hindu yang baik dan Bona Fide diselamatkan oleh Kristus dan bukan oleh Hinduisme, namun melalui Sakramen Hinduisme, melalui Mysterion yang datang padanya melalui Hinduisme, bahwa Kristus menyelamatkan orang Hindu secara wajar. $^{102}$

Konsep Karl Rahner tentang Kristen Anonim itu telah memberi pengaruh luas dan merupakan konsep inklusivisme Katolik. Itulah sebabnya Lesslie Newbigin dalam buku Injil Dalam masyarakat Majemuk, mengatakan: "Keselamatan melampaui batasbatas gereja yang kelihatan dan bukan saja individu-individu non-Kristen dapat diselamatkan, tetapi juga bahwa agamaagama bukan Kristen mempunyai peran menyelamatkan."103 Pengakuan bahwa setiap agama memiliki hal yang positif dan baik untuk diikuti, setidaknya menempatkan seseorang untuk mengakui bahwa semua agama dalam tatanan sosial dan moral adalah baik. Semua agama mengajar dan bahkan menjadi penuntun jalan yang benar dalam kehidupan moralitas umat manusia. Para pengikut suatu agama dituntun dan diarahkan untuk menjadi anggota masyarakat yang baik. Menerapkan prinsip dan pengajaran agamanya merupakan suatu kewajiban bagi para pemeluk suatu agama, dan sesuatu yang baik inilah yang harus

\footnotetext{
${ }^{102}$ Joas Adiprasetya, hlm. 70.

103 Lesslie Newbigin, Injil Dalam Masyarakat Majemuk, hlm. 244.
} 
dilihat sebagai suatu hal yang baik dari suatu agama.

Berpikir inklusif dalam beragama hanya akan membuat seseorang berada pada titik netral agama, yaitu sebuah titik yang tidak dapat diakui oleh kitab suci dan ajaran umum dalam agama manapun. Berpegang pada prinsip inklusif hanya akan membuat seseorang terpenjara dan bahkan bisa dikucilkan dalam pergaulan antar umat beragama. Itulah sebabnya wajar bila Micea Eliade, dalam buku The Encylopedia of Religion mengomentari inklusivisme sebagai "logically an unstable position". ${ }^{104}$ Jika demikian halnya maka berpikir secara inklusif hanyalah sebuah pembodohan karena menyangkali kebenaran hakiki sebab pikiran terbelenggu oleh piciknya wawasan antar agama.

Ada hal yang patut dipertimbangkan ketika membicarakan aspek inklisivisme dalam kehidupan beragama, yaitu bahwa seorang Kristiani tidak akan merasa lebih terhormat ketika dirinya disebut sebagai Muslim Generik atau telah berislam secara generik seperti yang diistilahkan oleh buku Fiqih Lintas Agama. Demikian juga seorang Muslim dimana mereka tidak akan merasa lebih senang ketika seorang Karl Rahner menyarankan untuk menyebut diri mereka sebagai Anonymous Christians. ${ }^{105}$

\section{Pluralisme}

Istilah Pluralisme merupakan sebuah istilah yang berasal dari kata plural, yang berarti ragam dan isme, yang berarti faham. Secara etimologi istilah pluralisme merupakan kata serapan dari bahasa Inggris yang terdiri dari dua kata,

\footnotetext{
104 Mircea Eliade (ed), The Encylopedia of Religion, (New York: Collier Macmillan Publishers, 1987) hlm. 331.

${ }^{105}$ Ibid.
}

yaitu Plural yang berarti ragam dan isme yang berarti faham. Jadi pluralisme bisa diartikan sebagai berbagai faham, atau bermacam-macam faham. Secara terminologi istilah pluralism merupakan suatu kerangka interaksi yang mana setiap kelompok menampilkan rasa hormat dan toleran satu sama lain, berinteraksi tanpa konflik atau asimilasi.

Secara khusus, pluralisme agama adalah pandangan, pikiran, keyakinan bahawa agama-agama yang bermacammacam dan berbeda-beda itu mempunyai kesamaan dari segi ontologi, soteriologi, dan epistemologi. Peter Byrne dalam buku Prolegomena to Religious Pluralism mengatakan bahwa: "Pluralisme agama merupakan persenyawaan tiga tesis. Pertama, semua tradisi agama-agama besar dunia adalah sama, semuanya merujuk dan menunjuk sebuah realitas tunggal yang transendent dan suci. Kedua, semuanya sama-sama menawarkan jalan keselamatan, dan Ketiga, semuanya tidak ada yang final. Artinya, setiap agama mesti senantiasa terbuka untuk dikritik dan ditinjau kembali. ${ }^{106}$

Pandangan pluralisme mengakui adanya kebenaran yang sama dalam agama-agama, meskipun berbeda-beda. Dasarnya adalah pengkajian kembali berita Alkitab, khususnya mengenai Kristologi. Pluralisme menggeser Kristosentris ke Theosentris, dengan dasar kitab Yohanes 14:28, 17:3; 1 Korintus 15:28, sikap teosentri Yesus, kitab Mazmur, nabi-nabi, dan filsafat agama. Menurut John Hick, pluralisme adalah pandangan yang menyatakan bahwa pe-rubahan hidup manusia dari keterpusatan pada diri sendiri menuju keterpusatan pada sang Realitas tunggal, yaitu Tuhan; terjadi di

\footnotetext{
106 Peter Byrne, Prolegomena to Religious Pluralism, (London: Macmillan Press, 1995), p. 191.
} 
dalam semua agama dalam pelbagai bentuk dan cara. ${ }^{107}$ Bagi Hick agamaagama yang ada dan dianut oleh para pengikutnya me-miliki kelebihan yang khas satu dengan yang lainnya. Itulah sebabnya pluralisme mem-berikan pernyataan dan perubahan hidup yang ke arah yang lebih baik.

Selain Hick, juga ada seorang yang bernama Paul F. Knitter yang dipandang aktif menyuarakan paham pluralisema. Menurutnya, pluralisme berangkat dari keinginan melahirkan dialog yang jujur dan terbuka sehingga seluruh pemeluk agama dapat bekerja-sama memperbaiki kehidupan dan menanggulangi penderitaan manusia di muka bumi ini. Dalihnya, terdapat suatu kesamaan yang kasar atau rough parity pada semua agama. Agama-agama selain Kristen mungkin juga sama baik dan pentingnya untuk membawa pengikut masing-masing kepada kebenaran, perdamaian dan kesejahteraan bersamaTuhan. ${ }^{108}$ Janganlah lupa bahwa kekerasan terhadap suatu agama dengan mengatasnakman suatu agama merupakan hal yang seringkali terjadi.

Menanggapi hal kekerasan terhadap suatu agama, Zuly Qodir dalam buku Islam Syariah vis-à-vis Negara, bahwa: "Kekerasan agama atau sacred violence selain muncul dari adanya teks-teks suci, dogma, dan tafsir agama, juga disebabkan karena agama dijadikan sebagai barang yang magis dan serba mutlak. Agama dipandang tidak bisa diinterpretasikan, apalagi disesuaikan dengan keinginan manusia. Dengan menjadikan agama sebagai berhala-berhala baru, orang beragama merasa dalam beragamanya paling

107 John Hick, Problems of Religious Pluralism, (New York: St. Martin Press, 1985), p. 34.

${ }^{108}$ John Hick dan Paul F. Knitter, Mitos Keunikan Agama Kristen, (Jakarta: BPK Gunung Mulia, 2001), hlm. 42-45. sempurna sehingga orang lain pasti salah dan harus dipertobatkan." 109

Sikap yang anti suatu agama sesungguhnya hanya akan menimbulkan keresahan dalam kehidupan bermasyarakat. Pluralisme agama haruslah mendapat tempat yang sesuai karena keragaman agama tidak bisa dihindarkan. Itulah sebabnya diperlukan sebuah sikap yang saling menghargai satu dengan lainnya. Soetarman dalam buku Fundamentalisme, Agama-Agama dan Teknologi mengutip pernyataan seorang tokoh gereja Indonesia, Eka Darmaputra yang berkata bahwa: "Semua agama tidak hanya didesak untuk memikirkan sikap praktis untuk bergaul dengan agama yang lain, tetapi juga didesak untuk memahami secara teologis apakah makna kehadiran agama-agama dan kepercayaankepercayaan yang lain itu."110 Pluralisme adalah sebuah asumsi yang meletakkan kebenaran agama-agama sebagai kebenaran yang relatif dan menempatkan agama-agama pada posisi setara, apapun jenis agama itu. Itulah sebabnya perlu sikap bijak dalam menanggapinya.

\section{Perkembangan Teologi Religionum}

Abdul Qadir Djaelani, dalam buku Sekitar Pemikiran Politik Islam, mengutip pendapat Quraish Shibab yang mengatakan: "Malapetaka dapat terjadi bukan saja karena umat beragama tidak memahami agama orang lain, tetapi juga karena ketidakmampuan untuk mengerti agamanya sendiri. Jika setiap pemeluk agama yang berbeda-beda itu didorong untuk menyusun kerangka teologis me-

\footnotetext{
109 Zuly Qodir, Islam Syariah vis-à-vis Negara, (Yogyakarta: Pustaka Pelajar, 2007), hlm. 225.

110 Soetarman, Weinata Sairin, dan Ioanes Rakhmat, Fundamentalisme, Agama-Agama Dan Teknologi, hlm 14-15
} 
nurut kacamata agamanya, setidaknya mereka didesak untuk menggali dari agamanya sendiri nilai-nilai positif yang mendukung bahkan menggiatkan hubungan-hubungan antar penganut agama-agama yang berbeda-beda itu, sehingga sedapat mungkin konflikkonflik yang tidak perlu dapat dihindarkan". ${ }^{111}$ Kesadaran akan keragaman agama perlu ditegaskan lagi supaya ada penerimaan atas agamaagama yang dimaksud. Pluraliame agama adalah upaya sadar untuk tidak sekedar menghormati pemeluk agama lain, tapi ikut pula bahu membahu bersama agama lain untuk membahas, bergerak membenahi bangsa, sosialkemasyarakatan, politik, kebudayaan hingga pada membela bangsa ketika terjadi intimidasi baik dari dalam negeri maupun luar negeri. Komunikasi semacam dialog antar umat beragama dianggap penting, untuk meng-hindari truth claim yang selama ini menjadi sesuatu yang merisaukan. ${ }^{112}$ Beberapa catatan pertikaian antar agama telah nyata dan jika hal itu dibiarkan maka akan berakibat buruk dalam kehidupan antar umat beragama. Itulah sebabnya perlunya suatu usaha bagi para pemeluk agamanya untuk memahami dengan betul agamanya, dan jika perlu juga agama orang lain. Dengan memahami agama yang diyakini dan agama orang lain, maka akan memberikan kontribusi pengertin serta pemahaman yang benar atas suatu agama. Pengetahuan atas suatu agama dianggap dapat memperkaya wawasan agama yang dimaksud.

111 Abdul Qadir Djaelani, Sekitar Pemikiran Politik Islam, (Jakarta: Media Da'wah, 1994), hlm. 46.

${ }^{112}$ Liza Wahyuninto, dan Abd. Qadir Muslim. Memburu Akar Pluralisme Agama, hlm. 6
Perkembangan teologi religionum tidak lepas dari beberapa hal yang mendahuluinya. Hal-hal yang dimaksudkan tersebut setidaknya memberikan kontribusi bagi perkembangan theologi agama-agama tersebut. Th. Sumartana, melalui buku Meretas Jalan Teologi Agama-Agama di Indonesia, mengatakan bahwa: "Teologi religionum, juga dikenal dengan istilah Teologi Agama-Agama atau Teologi of Religions; sesungguhnya merupakan cabang dari ilmu teologi yang membahas bagaimana kekeristenan memberi respons teologis terhadap kenyataan adanya pluralitas agama di luar dirinya." 113

\section{Adagium: Extra Yesum Christum Nulla Salus}

Adagium atau pepatah Extra Yesum Christum Nulla Salus, merupakan sebuah ungkapan yang sangat tegas dari gereja; berkaitan dengan soteriologi. Pernyataan ini sejalan dengan apa yang dikatakan Yesus Kristus, bahwa "Akulah jalan kebenaran dan hidup..." (lih. Yohanes 14:6). Dalam pernyataan yang dianggap ekslusivisme tersebut, kekristenan menyatakan diri bahwa hanya Yesus Kristus adalah Tuhan dan juruselamat umat manusia. Herman Riderbos, dalam buku yang berjudul, Paulus: Pemikiran Utama Teologinya, menyatakan: "Bagi Yudaisme, Taurat adalah penangkal penting bagi ancaman dan kuasa dosa. Taurat adalah sarana penting untuk mendapatkan kebenaran di hadapan Allah."114 Bagi bangsa Israel, Taurat

\footnotetext{
${ }^{113}$ Lih.Th. Sumartana. "Theologia Religionum". Di dalam Meretas Jalan Teologi Agama-Agama di Indonesia. Tim Balitbang PGI (Eds.). (Jakarta: BPK Gunung Mulia, 2007), hlm. 56.

${ }^{114}$ Herman Riderbos, Paulus: Pemikiran Utama Teologinya, (Surabaya: Penerbit Momentum, 2010), hlm. 135.
} 
merupakan pegangan hidup yang melembaga dalam kehidupan setiap hari dimana hal tersebut menjadi pegangan dan tolok ukur untuk setiap langkah kehidupan mereka. Dalam Taurat, orang Israel yang menerapkan prinsip-prinsip penting diterapkan dalam hal pengambilan keputusan etis. Setidaknya hendak dinyatakan bahwa Taurat menjadi kunci bagi setiap pengambilan keputusan moral dalam hidup orang Israel. Riderbos melihat Yudaisme sebagai hal yang penting dalam kehidupan umat Yahudi, dimana Yudaisme dianggap mampu membentengi umat dari berbagai hal yang membahayakan kehidupan spiritualnya, dan juga dapat berfungsi sebagai senjata untuk melawan hal-hal yang tidak baik. Lebih lanjut Riderbos menjelaskan bahwa Yudaisme tidak mengenal jalan keselamatan selain oleh Taurat. Israel memeluk taurat sebagai sumber keselamatan.Taurat dianggap sanggup memberikan hidup kepada manusia dan melakukan taurat dapat mengurangi hukuman dosa. ${ }^{115}$

Pepatah Extra Ecclesiam Nulla Salus atau diluar gereja tidak ada keselamatan, kini semakin direlativasikan, diperlemah dan bahkan pada akhirnya dikosongkan. Dalam Extra Ecclesiam Nulla Salus, muncullah istilah lain yang memiliki kedekatan dalam pengertian bahwa kekristenan merupakan sesuatu yang sudah final dalam artian doktrin soteriologi. Istilah itu adalah: Extra Yesum Christum Nulla Salus, yang berarti diluar Yesus Kristus tidak ada keselamatan.

Dalam perjalanan sejarah gereja Katolik terdapat sebuah dogma yang amat kontroversial namun dogma ini adalah dogma kebenaran, dogma yang berasal dari Allah sendiri. Dan dari

115 Ibid, 132 dogma ini tergambarlah wujud dan realita Gereja sebagai Tubuh Kristus di dunia. Doktrin itu ialah Extra Ecclesiam Nulla Salus. Begitu banyak orang yang menyalahgunakan bahkan salah tafsir mengenai dogma ini. Sementara pada zaman ini, orang-orang menganggap bahwa keselamatan bisa datang dari mana saja dan memandang bahwa doktrin Extra Ecclesiam Nulla Salus merupakan dogma yang ketinggalan zaman dan sudah lenyap setelah Konsili Vatikan II diselenggarakan.

Sejak Konsili Vatikan II, nilai kristiani, khususnya gereja Katholik mengalami perubahan. Dari yang tadinya sangat kuat pada konsep ekslusivisme, kini mulai membuka diri pada konsep pluralisme. Dalam isu perkembangan gereja Katholik, ada kecenderungan bahwa setelah Konsili Vatikan II, banyak Uskup, Imam dan kaum klerus dan awam menyatakan bahwa dogma Extra Ecclesiam Nulla Salus, telah dihapus oleh Konsili Vatikan II. Mereka menganggap bahwa dogma tersebut merupakan ajaran Gereja pra-Vatikan II dan pada paska Konsili Vatikan II dengan memegang perkataan Paus Yohanes XXIII yang pada intinya mengatakan bahwa gereja harus bersifat dinamis; maka doktrin Extra Ecclesiam Nulla Salus, berubah menjadi diluar gereja ada keselamatan. Ini adalah paham yang sangat keliru, dan perlu diketahui bahwa Gereja pra-Vatikan II dan Gereja paska-Vatikan II adalah pembagian yang ambigu. Pola pikir semacam ini dapat memberi kesan negatif bagi gereja, bahwa ajaran gereja terus berubah sepanjang zaman, walaupun ada upaya untuk mengembalikan supremasi Kristus melalui Dekrit Dominus Jesus yang dikeluarkan Paus Yohanes Paulus II pada tahun 2000 untuk menjawab pluralisme; sebagaimana yang sudah disinggung sebelumnya. 
Dalam adagium Extra Ecclesiam Nulla Salus, muncul lagi adagium yang lebih spesifik, yaitu Extra Yesum Christum Nulla Salus yang berarti diluar Yesus Kristus tidak ada keselamatan. Adagium inipun kini tersimpan diperpustakaan sebagai curiosum atau pujian dari keyakinan gereja pada masa yang lampau. Keyakinan Perjanjian Baru, bahwa Extra Christum Nulla Salus, kini telah mengalami perubahan yang drastis, dimana doktrin tersebut sudah direlativisasikan.

\section{Gerakan Renaisance dan Enlightenment}

Istilah Renaissance berasal dari bahasa Latin renaitre yang berarti hidup kembali atau lahir kembali. Pengertian renaissance adalah menyangkut kelahiran atau hidupnya kembali kebudayaan klasik Yunani dan Romawi dalam kehidupan masyarakat Barat. Dalam pengertian yang lebih spesifik, renaissance diartikan sebagai suatu periode sejarah di mana perkembangan kebudayaan Barat memasuki periode baru dalam semua aspek kehidupan manusia, seperti ilmu-ilmu pengetahuan, teknologi, seni dalam semua cabang, perkembangan sistem kepercayaan, perkembangan sistem politik, institusional, bentuk-bentuk sistem kepercayaan yang baru dan lainlain.

Secara historis renaissance adalah suatu gerakan yang meliputi suatu zaman di mana orang merasa dirinya telah dilahirkan kembali dalam keadaban. Di dalam kelahiran kembali itu orang kembali pada sumber-sumber murni bagi pengetahuan dan ke-indahan. Dengan demikian orang memiliki norma-norma yang senantiasa berlaku bagi hikmat dan kesenian manusia.
Renaissance lahir di Italia pada abad ke-14, terutama di Italia Utara dimana kota-kota bertambah kaya oleh perniagaan, perusahaan, dan kerajinan penduduk. Masyarakat kota itu makin lama makin makmur, makin sadar akan kepentingan dirinya dan makin berkuasa. Dengan demikian, berkembanglah suatu pandangan hidup yang baru, yang antara lain ternyata dalam syair-syair pujangga Petrarca (1304-1374), yang berbunyi demikian: "Sebenarnya manusia tak usah mengikuti kuasa apa pun di atasnya; kaidah dan pusat hidup manusia ialah pribadinya sendiri." ${ }^{\text {.116 }}$ Sikap tersebut berhubungan rapat dengan pandangan penyair-penyair Romawi dan Yunani zaman purba, yang telah lama dikenal, tetapi baru sekarang disadari dan diulangi. Pusat pergerakan renaissance adalah Florensa dan Roma.

Pemakaian kata Renaissance untuk pertama kalinya dipergunakan oleh Jules Michelet, seorang sejarawan Perancis yang lahir di abad ke-18 dan mulai terkenal di dunia Barat pada abad ke-19 karena karyanya yang berjudul History of France yang menekankan bahwa masa romatik Abad Pertengahan bukanlah sama sekali tidak berguna bagi perkembangan kebudayaan Barat. ${ }^{117}$

Jules Michelet (1798-1874) adalah sejarawan pertama yang memperkenalkan kata Renaissance; dan ia membedakan antara masyarakat Renaissance dengan masyarakat Abad Pertengahan adalah pada penafsiran pelaksanaan agama dalam kehidupan masyarakat. Menurut Jules Michelet, Abad Pertengahan ditandai oleh faktor dogmatis, sedangkan

\footnotetext{
116 Linda Suryanegara, Sejarah Pemikiran Renaissance, (Jakarta: Penerbit Literatur GKKI, 2011), hlm. 67.

117 Ibid, hlm. 22.
} 
manusia Renaissance ditandai oleh faktor humanis. 118

Renaissance mempunyai arti penting dalam sejarah kebudayaan Barat. Renaissance adalah masa kekuasaan, kesadaran, keberanian, kepandaian yang luar biasa, kebebasan dan seringkali semua itu tidak ada batasnya. Orang yang terpengaruhi oleh gerakan Renaissance ditandai dengan pemilikan ilmu pengetahuan lebih dari satu. Mereka terlihat menguasai banyak ilmu pengetahuan. Agama menjadi hal yang hanya mengenai individu, perhatian orang lebih banyak ditujukan untuk dunia. Pada zaman renaissance, manusia hidup bebas dalam menentukan corak hidupnya dan tidak lagi terikat oleh doktrin gereja.

Pengaruh Renaissance makin lama makin meresap di berbagai bidang hidup, sehingga bertambah banyak orang, teristimewa dari golongan cendekiawan, mulai melepaskan diri dari kuasa Firman Tuhan. Ilmu pengetahuan dan kebudayaan umum mulai memisahkan diri dari ajaran dan dogma agama Kristen. Terutama ilmu alam yang berdasarkan ilmu pasti, mulai bertentangan dengan pandangan gereja yang sampai masa itu diajarkan dan dipercaya sebagai kebenaran ilahi. Selain Renaissance ada juga Pencerahan. Pencerahan atau Enlightenment merupakan istilah yang digunakan untuk menggambarkan aliran utama pemikiran yang berkembang di Eropa dan Amerika pada abad ke-18. Perkembangan di bidang ilmu pengetahuan dan intelektual pada abad ke-17, seperti; penemuan-penemuan Isaac Newton, munculnya aliran pemikiran Rasionalisme oleh Rene Descartes, atau pemikiran skeptismenya Pierre Bayle, Panteismenya Benedict de Spinoza, dan

118 Ibid, hlm. 23. filsafat Empirisme dari Francis Bacon dan John Locke, sangat menunjang berkembangnya kepercayaan terhadap hukum alam dan prinsip universal. ${ }^{119}$

Perkembangan sebagaimana disebutkan diatas tersebut menumbuhkan rasa kepercayaan akan kemampuan akal manusia, dan hal ini tersebar hingga mempengaruhi pola pikir seluruh masyarakat Eropa dan Amerika pada abad ke-18. Arus-arus pemikiran pada masa itu cukup banyak dan bervariasi, akan tetapi beberapa ide dapat digolongkan sebagai ide hasil serapan dan ide dasar. ${ }^{120}$ Pada masa Pencerahan, pendekatan berdasarkan rasio dan ilmu pengetahuan terhadap persoalan agama, sosial, dan ekonomi menjadi tren di masyarakat, sehingga hal ini menghasilkan sebuah pandangan yang bersifat duniawi atau sekuler dan juga membangun opini umum tentang kemajuan dan kesempurnaan di berbagai bidang.

Di Inggris Pencerahan dikenal dengan istilah Enlightenment, sedangkan di Perancis dengan istilah Lumières dan di Jerman dengan die Aufklärung. Ide Pencerahan kemudian tersebar ke seluruh Eropa, dan bahkan hingga ke daerahdaerah koloni di Amerika. Penyebarannya adalah melalui buku-buku karya filsuf Pencerahan, atau lewat diskusi-diskusi yang menjadi kebiasaan masyarakat pada masa itu.

Gerakan Pencerahan muncul sebagai suatu bentuk penolakan terhadap situasi di mana jati diri manusia adalah jati diri yang terkungkung dan tertindas oleh aturan-aturan baku yang dianggap irasional yang diberlakukan oleh pihak gereja sejak Abad Pertengahan, yaitu dalam masa periode tahun 400-an Masehi hingga tahun 1500-an. Gerakan ini juga

\footnotetext{
119 Ibid, hlm. 43.

${ }^{120}$ Ibid.
} 
merupakan reaksi terhadap situasi politik di mana pihak penguasa, yaitu para raja dengan sistem monarki di Eropa menerapkan politik absolut yang juga sudah berlaku sejak abad pertengahan dimana mereka raja atau ratu sebagai pemegang kekuasaan tertinggi dalam pemerintahan dan hal ini dianggap merugikan rakyat yang sudah terbelenggu sistem tersebut.

Pada masa Abad Pertengahan manusia memandang dirinya bukan sebagai makhluk yang bebas. Manusia bukan pula makhluk yang diajarkan bagaimana menjawab persoalanpersoalan hidupnya secara nyata. Ia adalah individu yang harus hidup dalam satu cara berpikir dan hanya boleh memikirkan satu hal, yakni bagaimana hidup menurut ajaran atau dogmatika yang di ajarkan oleh gereja. Pandangan ini masih cukup berpengaruh di Eropa hingga awal abad ke-18. Pada dasarnya Gerakan Pencerahan dengan kritis mempertanyakan dan berusaha merombak pandangan umum terhadap kepercayaankepercayaan tradisional, adat-istiadat, dan sistem-sistem moral yang merupakan warisan dari abad sebelumnya. Dalam perkembangannya, masa Pencerahan ditandai dengan perubahan iklim di bidang politik, seperti; terbentuknya sistem pemerintahan parlementer, konsolidasi pemerintahan, pembentukan negara, terciptanya undang-undang hak rakyat dan juga kemunduran pengaruh pihak monarki dan pihak gereja dalam sistem pemerintahan. $^{121}$

Pencetus ide pencerahan adalah seorang filsuf Jerman, Immanuel Kant (1724-1804), yang menulis tentang pencerahan dalam sebuah artikel berjudul: Was Heisst Aufklarung? ${ }^{122}$ di

121 Ibid, hlm. 51

${ }^{122}$ Artikel yang berjudul Was Heisst Aufklarung? Adalah tulisan Immanuel Kant (1724-1804) yang merupakan jawaban atas tulisan Johann Friedrich sebuah Harian Berlin Berlinische Monatschrift, pada tahun 1784. Tulisan itu merupakan refleksi atas situasi kontemporer Eropa ketika itu. Terjadi perubahan besar dalam kehidupan politik, ekonomi, sosial, kebudayaan, dan keagamaan yang belum pernah terjadi sebelumnya. ${ }^{123}$

Dengan demikian maka ciri utama renaissance adalah humanisme, indvidualisme, rasionalisme, empirisma dan lepas dari agama. Gambaran dari ciri khas renaissance tersebut setidaknya membuka wawasan kepada banyak orang sehingga bisa bersikap menerima atau tidak atas paham renaissance. Hal yang hampir sama juga ada dalam Enlightenment. Karena dogmatika agama dianggap musuh rasionalitas, maka renaissance dan Enlightenment tumbuh subur. Ketika agama hendak dipergunakan, maka ia harus mengakomodasi gejolak yang ada sehingga nilai esensial yang dianggap bertentangan dengan prinsip renaissance dan enlightenment harus diubah.

\section{Konsili Vatikan II (1962-1968)}

dan juga dikenal sebagai Konsili

Zöllner (1753-1804) tentang "Apa itu Pencerahan?" dalam tulisannya itu Immanuel Kant mengatakan bahwa pencerahan adalah munculnya manusia dari ketidakmatangan diri yang ada padanya. Ketidak-dewasaan adalah ketidakmampuan untuk memiliki pemahaman tanpa bimbingan lain. Bahkan yang terjadi adalah ketidakmampuan dalam pemahaman. Kant menyatakan perlunya seseorang untuk memiliki keberanian untuk menggunakan pemahaman sendiri. Inilah yang kemudian dikenal sebagai moto pen-cerahan. (https://de.wikipedia.org/wiki/ Beantwortung_der_Frage:_Was_ist_Aufklärung?, Diakses pada hari Senin, tanggal 16 Februari 2018, pukul 11.10 WIB.

123 Linda Suryanegara, Sejarah Pemikiran Renaissance, hlm. 49 
Ekumenis Vatikan Kedua; merupakan sebuah sebuah Konsili Ekumenis ke-21 yang diselenggarakan Gereja Katolik Roma. Konsili Vatikan II yang dibuka secara resmi oleh Paus Yohanes XXIII pada 11 Oktober1962 dan ditutup oleh Paus Paulus VI pada 8 Desember1965. Pembukaan Konsili ini dihadiri oleh hingga 2540 orang uskup Gereja Katolik Roma sedunia, yang kemudian para uskup tersebut disebut para Bapa Konsili). Turut juga hadir sebanyak 29 pengamat dari 17 Gereja lain, dan para undangan yang bukan Katolik.

Selanjutnya Konsili Vatikan II (1962-1968), telah dikeluarkannya sejumlah deklarasi, dan salah satunya adalah deklarasi mengenai hubungan antara gereja dengan agama-agama bukan Kristen, sebagaimana yang sudah disebutkan sebelumnya. Pemimpin gereja Roma Katolik pada waktu itu, Paus Paulus VI memperhatikan bahwa ada kekayaan agama pada bangsa lain, dan kekayaan itu perlu digali sedemikian rupa sehingga dapat dimanfaatkan bagi ke-sejahteraan umat manusia. Itulah sebabnya jika tadinya semboyan Extra Yesum Christum Nulla Salus merupakan sebuah ketegasan atas doktrin Kristen, kini mengalami distrosi.

Semua agama memiliki keunikan dan bahkan juruselamatnya masingmasing. Kekristenan tidak bisa menyatakan dirinya paling benar karena memiliki Kristus. Agama lainpun memiliki peluang yang sama untuk diselamatkan. Jika Katlolik dengan Konsili Vatikan II, maka kalangan Kristen meng-akomodasi pluralisme dan menghargainya sebagai bagian dari kehidupan bermsyarakat. Setidaknya hal itu dapat dilihat dari hasil Sidang Raya Dewan Gereja Sedunia keIV di Upsala, yang akan dibahas kemudian.
Konsili Vatikan II menghasilkan 16 dokumen penting dalam peradaban gereja dan umat manusia. Konsili Vatikan II masuk dalam pembahasan desertasi ini karena salah satu dokumen yang dihasilkannya merupakan sebuah pergumulan dalam kehidupan umat manusia, yaitu berkaitan dengan kepercayaannya dan kepercayaan orang lain. Dokumen yang dihasilkan tersebut merupakan sebuah kebijakan gereja yang dikemudian hari memberikan dampak bagi umat. Dokumen yang dimaksudkan tersebut adalah: Nostra Aetate yaitu hal hubungan gereja dengan agama-agama yang bukan Kristen.

\section{Sidang Raya Dewan Gereja Sedunia di Upsala (1968)}

World Council of Churches (WCC), atau Dewan Gereja Sedunia merupakan perhimpunan Gereja-gereja sedunia, yang bertujuan untuk membentuk kesatuan di antara umat Kristen. Setidaknya organisasi yang mempunyai anggota sebanyak 340 Gereja dan denominasi yang berasal dari 100 negara di seluruh dunia, dengan mewakili sekitar 550 juta orang Kristen. ${ }^{124}$ Anggota denominasi organisasi ini dari berbagai gereja seperti Anglikan, Baptis, Lutheran, Methodis, dan Reformasi, serta banyak gereja independen atau bersatu lainnya. Gereja-gereja yang mendirikan organisasi ini pada mulanya adalah gereja-gereja yang terletak di Eropa dan Amerika Utara, namun kini kebanyakan anggotanya tersebar di Afrika, Asia, Karibia, Amerika Latin, Timur Tengah, dan Pasifik.

Organisasi Dewan Gereja se-Dunia ini terbentuk pada Sidang Rayanya yang

\footnotetext{
124 https://id.wikipedia.org/wiki/Dewan_Gerejagereja_se-Dunia, Diakses pada hari Senin, tanggal 23 Maret 2018, pukul 10.15 WIB.
} 
pertama di Amsterdam, Belanda, pada 23 Agustus 1948, ditandai dengan bergabungnya dua kelompok ekumenis. Kemudian Kelompok yang ketiga, yaitu sebuah gerakan misionaris yang terbentuk pada Sidang Misi Internasional (IMC), menyatakan bergabung dengan DGD tepat pada Sidang Raya yang ketiga di New Delhi, India (1961). Kelompok yang keempat yang ikut bergabung adalah Dewan Pendidikan Kristen seDunia (WCCE), pada tahun 1971, dan hingga kini ada begitu banyak anggota yang ada dalam organisasi ini.

Sidang Raya Dewan Gereja seDunia (DGD) telah diselenggarakan sebanyak sembilan kali, yaitu: Sidang Raya I dengan tema "Kekacauan Manusia dan Rancangan Allah" di Amsterdam-Belanda (1948), Sidang Raya II dengan tema "Kristus - Pengharapan Dunia" di Evanston, Illinois-Amerika Serikat (1954), Sidang Raya III dengan tema "Kristus Terang Dunia" di New Delhi-India (1961), Sidang Raya IV dengan tema "Lihatlah, Aku Jadikan Semuanya Baru" di Uppsala-Swedia (1968), Sidang Raya V dengan tema "Yesus Kristus Membebaskan dan Mempersatukan", di Nairobi-Kenya (1975), Sidang Raya VI dengan tema "Yesus Kristus-Terang Dunia" di Vancouver-Kanada (1983), Sidang Raya VII dengan tema "Datanglah ya Roh Kudus-Perbaruilah Seluruh Ciptaan", di Canberra-Australia (1991), Sidang Raya VIII, dengan tema "Berbaliklah kepada Allah-Bersukacitalah di dalam Pengharapan", di Harare-Zimbabwe (1999), Sidang Raya IX dengan tema "Ya Allah, di dalam Anugerah-Mu, Perbaruilah Dunia", di Porto AlegreBrasil (2006), dan yang terakhir adalah Sidang Raya X dengan tema "Ya Allah Kehidupan, Pimpin Kami kepada
Keadilan dan Perdamaian", di BusanKorea Selatan (2013). ${ }^{125}$

Penyelenggaraan Sidang Raya DGD selalu memberikan jawaban atas pergumulan umat sepanjang sejarah, dan berkaitan dengan isu teologi agamaagama, maka yang patut dicermati adalah Sidang Raya Dewan Gereja Sedunia keIV yang diselenggarakan di kota Upsala pada tahun 1968. Sidang Raya dengan tema "Lihatlah, Aku Jadikan Semuanya Baru" telah melahirkan sebuah kesepakatan mengenai agama-agama lain yang dianggap memiliki kesetaraan dengan kekristenan. Dengan demikian maka agama-agama lainpun mengandung kebenaran dan agama Kristen tidak bisa menyatakan dirinya sebagai satu-satunya agama yang paling benar. Janganlah lupa bahwa sidang raya di Upsala itu memberikan tekanan pada dimensi horisontal, yaitu pendamaian diantara umat manusia. $^{126}$ Dalam Sidang Raya ke-IV di Uppsala, Swedia, pada tahun 1968, para peserta merumuskan sikap theologis dari kalangan gereja protestan terhadap agama-agama lain yang harus terbuka. Misalnya, aspek Perintah Amanat Agung atau penginjilan dihilangkan di dalam tugas gereja dan diarahkan pada dialog lintas agama. Konsep keselamatan, diubah menjadi keselamatan manusia dari penderitaan di dunia, konsep berita Injil diubah menjadi Social Gospel. ${ }^{127}$ Persidangan Uppsala tersebut sesungguhnya menjadi benih awal atas terbukanya gereja terhadap agama-agama lainnya diluar Kristen. Keterbukaan yang dimaksud bukan hanya sebatas relasi kemasyarakatan, melainkan lebih men-

\footnotetext{
125 Ibid.

126 Ibid.

${ }^{127}$ Roger Hedlund, "Document Seventeen, Section II of the Uppasala Report”, Roots of the Great Debate in Mission, (Bangalore: Theological Book Trust, 1997), hlm. 243.
} 
dalam pada aspek dogmatika. Tentunya hal tersebut memberikan pengaruh pada konsep teologis mengenai misi dan hakekat gereja itu sendiri. Rumusanrumusan dari hasil persidangan Uppsala telah menjadi pemicu dan pendorong untuk theologi religionum berkembang di gereja-gereja di dunia dan juga di Indonesia. ${ }^{128}$

\section{Teologi Religionum di Indonesia}

Perkembangan gerakan Teologi Religionum di Indonesia tidak lepas dari beberapa faktor yang mempengaruhinya. Pada saat konflik yang terjadi dibeberapa daerah, sesungguhnya pemerintah dapat memanfaatkan kebersamaan sesama masyarakat Indonesia yang berada dalam gejolak pluralitas. Dalam kerangka Negara kesatuan dan Pancasila sebagai dasarnya serta semangat tolerasi antar umat Bergama; telah memberikan kesempatan bagi tumbuhnya gerakan teologi religionum di Indonesia.

Sejak awal berdirinya, negara republik Indonesia merupakan negara dengan penduduk multi etnik dan multi kepercayaan atau agama. Berdasarkan data statistik pada tahun 2010 menyebutkan bahwa setidaknya terdapat lebih dari 300 kelompok etnik atau suku bangsa di Indonesia, dan sesungguhnya Indonesia dikenal sebagai suatu sosok masyarakat yang pluralistik yang memiliki banyak kemajemukan dan keberagaman dalam hal agama, tradisi, kesenian, kebudayaan, cara hidup dan pandangan nilai

128 Olaf Schumann, Dialog antar Umat Beragama, Di manakah kita berada kini?, (Jakarta: LPS-DGI, 1980), hlm. 57. (lihat juga. Ioanes Rakhmat, Pluralitas Agama, Dialog dan Perspektif, hlm. 70.). yang dianut oleh kelompok-kelompok etnis dalam masyarakat Indonesia ${ }^{129}$

Pada masa sekarang ini umat beragama seringkali dihadapkan pada tantangan yang seringkali melahirkan benturan-benturan atau konflik di antara mereka. Konflik horisontal yang paling nyata di Indonesia; dan diduga berkaitan dengan hal agama adalah konflik antar umat beragama di Poso. Potensi pecahnya konflik antar pemeluk agama yang dimaksudkan tersebut sangatlah besar.

Hal pertikaian dalam masyarakat yang dimaksud harusnya dapat dengan mudah dipahami oleh semua pihak. Menurut Samuel P. Huntington, unsurunsur pembatas objektif adalah bahasa, sejarah, agama, adat istiadat, dan lembaga-lembaga. Unsur pembatas subjektifnya adalah identifikasi dari manusia. Perbedaan antar pembatas itu adalah nyata dan penting. ${ }^{130}$ Th. Sumartana mengatakan:" Tantangan keagamaan yang mendasar yang dihadapi sekarang ini bisa kita ungkap dengan satu kata, yaitu pluralisme. Tidak ada maksud untuk mengatakan bahwa pluralisme merupa-kan satu-satunya tantangan akan tetapi bila tantangan itu tidak diperhatikan dengan sungguh-sungguh, maka agama-agama akan kehilangan persepsi yang benar tentang dunia dan masyarakat sekarang. Pluralisme telah menjadi ciri esensial dari dunia masyarakat sekarang. Dunia telah menjadi satu dan menjadi kampung kecil di mana umat manusia hidup bersama di dalamnya. ${ }^{131}$

129 Faisal Ismail, Islam Idealitas Ilahiyah dan Realitas Insaniyah, (Yogyakarta: Tiara Wacana Yogya, 1999), hlm. 193.

130 Samuel P. Huntington, "Benturan Antar Peradaban, Masa Depan Politik Dunia?" dalam Jurnal Ulumul Qur'an, No. 5, Vol.IV Tahun 1993, hlm. 12.

${ }^{131}$ Th. Sumartana, Theologia Religionum, dalam Tim Balitbang PGI (Peny.), Meretas Jalan Teologia Agama-Agama di Indonesia, hlm. 18. 
Kemajemukan masyarakat dalam suatu kelompok merupakan suatu hal yang nyata dan tak dapat diabaikan begitu saja. Itulah sebanya semua pihak harusnya menerima kenyataan tersebut sebagai sebuah keragaman yang indah. Kenyataan akan keberagaman yang dimaksud harusnya memberikan pengetahuan akan keadaan masyarakat yang majemuk. Muhammad Imarah, dalam buku, Islam dan Pluralitas: Perbedaan dan Kemajemukan dalam Bingkai Persatuan, mengatakan: "Pada suatu sisi pluralistik dalam bangsa Indonesia bisa menjadi positif dan konstruktif tetapi di sisi lain juga bisa menjadi sebuah kekuatan yang negative dan destruktif yang dapat berakibat pada disintegrasi bangsa. Kenyataannya sejarah masyarakat adalah multi-complex yang mengandung religious pluralism. Hal ini adalah realitas, karena itu mau tidak mau kita harus menyesuaikan diri, dengan mengakui adanya religious pluralism dalam masyarakat Indonesia. ${ }^{132}$ Pernyataan Imarah tersebut hendak menghentakan pihak-pihak yang terkait di dalamnya untuk mulai merenungkan sesuatu yang baik bagi bangsa ini. Isu pluralisme di Indonesia memberi dampak yang negatif maupun positif.

Gerakan teologi religionum di Indonesia baru dikenal dalam beberapa tahun terakhir ini. Gerakan ini merupakan sebuah upaya dalam membangun jembatan dialog antar umat beragama; sebagaimana yang diupayakan semua pihak di Indonesia. Toleransi yang terus diupayakan untuk dikembangkan di Indonesia akan sangat memberi manfaat bagi masyarakat Indonesia yang plural, namun bukan berarti hal tersebut di-

132 Muhammad Imarah, Islam Dan Pluralitas: Perbedaan Dan Kemajemukan Dalam Bingkai Persatuan, (Jakarta: Gema Insani, 1999), hlm. 11. terima begitu saja. Ada hal yang harus dipikirkan lebih serius berkaitan dengan perkembangan kekristenan di Indonesia.

Olaf H. Schumann, dalam buku Menghadapi Tantangan Memperjuangkan Kerukunan, mengatakan: "Konsep toleransi beragama relative baru dalam sejarah umat beragama. Oleh sebab itu, tidak mengherankan masalah ini masih sering diperdebatkan. Selain itu, tuntutat terhadap toleransi beragama juga tidak berasal dari pertimbangan-pertimbangan teologis maupun religious. Toleransi beragama merupakan tuintutan yang dikedepankan ketika keseluruhan struktur masyarakat berada dalam situasi kritis, kemudian berbagai teori dikembangkan untuk membangun sebuah masyarakat baru, meninggalkan sistem sosial lama yang tradisional agar lebih bebas menciptakan masyarakat baru yang modern. ${ }^{133}$ Hal toleransi umat bergama di Indonesia mendapat perhatian banyak pihak, baik didalam maupun di luar negeri. Dalam suatu sisi, Indonesia merupakan Negara berpenduduk Muslim terbesar di dunia, namun pada sisi yang lain, Indonesia bukanlah Negara agama. Dengan demikian maka tumbuh subur agama-agama yang minoritas terus dijamin.

\section{Keragaman Keagamaan di Indonesia}

Keragaman hidup beragam di Indonesia hingga kini terus terpelihara. Walaupun ada beberapa konflik agama yang terkobar di beberapa daerah namun hal itu tidak mengurangi perhatian pemerintah pada pola hidup rukun antar agama. Keragaman agama inilah yang memberikan tantangan bagi beberapa teologi untuk mencoba membangun

133 Olaf H. Schumann, Menghadapi Tantangan Memperjuangkan Kerukunan, (Jakarta: BPK. Gunung Mulia, 2009), hlm. 42. 
hubungan antar agama yang lebih baik lagi. Hubungan yang lebih baik dalam kehidupan beragama perlu dibangun secara murni dan bertanggung jawab, namun tetap dalam kerangka uniknya suatu agama. Dialog antar agama diperlukan dalam hal ini. Dadang Kahmad, dalam buku Sosiologi Agama, mengatakan: "Dialog antaragama itu hanya bisa dimulai bila ada keterbukaan sebuah agama terhadap agama lainnya. Persoalannya mungkin baru muncul bila kemudian mulai dipersoalkan secara terperinci apa yang dimaksud keterbukaan itu, segi-segi mana dari suatu agama yang memungkinkan dirinya terbuka terhadap agama lain, pada tingkat mana keterbukaan itu dapat dilaksanakan. Lalu, dalam modus bagaimana keterbukaan itu bisa dilakukan. ${ }^{134}$ Bagi Kahmad, dialog antar agama dapat terjadi apabila ada keterbukaan suatu agama terhadap agama lainnya, dan hal itu hanya dapat terjadi jika perbedaan yang hakiki diantaranya dihilangkan. Selama hal yang menjadi penghalang terjadinya komunikasi dan relasi antar agama tidak diminimalisasi secara benar maka sulit bagi siapapun untuk membangun hubungan yang dimaksud. Salah satu sikap yang diusulkan untuk dikebangkan dalam hal tersebut adalah upaya untuk menghargai kesamaan setiap agama. Lebih lanjut dikatakan: "Bagi kami semua agama mengajarkan kebaikan. Tidak ada agama yang mengajarkan keburukan. Maka saya katakan bahwa semua itu sama dalam arti semua agama menginginkan kebaikan, mengajarkan keluhuran, mengajarkan kemanusiaan. Perbedaan ada, tetapi juga ada persamaan. Nah ini yang tidak dilihat orang yang mengharamkan pluralisme. ${ }^{135}$ Ketika mem-

\footnotetext{
${ }^{134}$ Dadang Kahmad, Sosiologi Agama, (Bandung: Remaja Rosdakarya, 2006), hlm. 174.

${ }^{135}$ Ibid, hlm. 177.
}

bicarakan hal agama dalam konteks humanistik maka setiap agama pasti mengajarkan kebaikan.

Prinsip agama adalah mengatur orang untuk hidup lebih baik. Sayangnya dalam kekristenan, hal yang baik bukanlah ada pada diri manusia, melainkan hanya ada pada Tuhan. Manusia yang sudah berdosa, tidak ada lagi kebaikan dalam dirinya. Itulah sebabnya perbedaan paradigma Kristen dengan agama lain haruslah dipertimbangkan.

\section{Gerakan Pluralisme Agama di Indonesia}

Sebagaimana yang sudah diuraikan pada bagian sebelumnya tentang definisi kata pluralisme, maka sedikit memberikan gambaran ulang bahwa secara etimologis, asal kata pluralisme berasal dari kata bahasa Inggris, pluralism yang berarti plural (beragam), jamak, atau majemuk. Sedangkan secara terminologis, pluralisme yaitu suatu pandangan atau paham yang memiliki prinsip bahwa keanekaragaman itu jangan menghalangi untuk bisa hidup berdampingan secara damai dalam satu masyarakat yang sama. ${ }^{136}$ Berangkat dari definisi pluralisme, maka pluralisme agama adalah "sebuah pandangan yang mendorong bahwa berbagai macam agama yang ada dalam satu masyarakat harus saling mendukung untuk bisa hidup secara damai. ${ }^{137}$

Banyak kalangan mengakui peran cendekiawan muslim Nurcholish Madjid sebagai pelopor masuknya pluralisme

\footnotetext{
136 Mundzirin Yusuf, Islam dan Budaya Lokal, (Yogyakarta: Pokja Akademik UIN Sunan Kalijaga, 2000), hlm.30.

137 Khadziq, Islam Budaya Lokal Memahami Realitas Agama dalam Masyarakat, (Yogyakarta: Penerbit Teras, 2009) hlm. 223.
} 
agama di Indonesia. Kehadiran pluralisme agama di Indonesia dengan dalih mencegah dan meredam konflik antar umat beragama terus menggema. Sayangnya pluralisme agama bukanlah sekedar toleransi antar umat beragama yang sering di suarakan oleh para pendukung pluralisme agama. Pluralisme agama adalah sebuah upaya untuk menuntut kesamaan dan kesetaraan (equality) dalam segala hal antar agama.

Dengan perkembangan yang ada, maka Fatwa Majelis Ulama Indonesia (MUI), berkaitan dengan plaralisme agama dikeluar-kan.Wacana pluralisme di tanah air tampak begitu ramai setelah MUI menerbitkan fatwa pada tahun 2005, yang pada dasarnya meng-haramkan segama macam bentuk pluralism agama di Indonesia. Bagi MUI, pluralisme agama melanggar kaidah Islam karena persekutuan antara Islam dengan kekafiran terjadi. Dengan keluarnya fatwa tersebut maka pendukung pluralisme agama di Indonesia dipukul dengan telak oleh fatwa MUI tersebut. Namun demikian, fatwa terebut dianggap sepi oleh para tokoh pluralisme agama yang berasal dari berbagai agama di Indonesia.

\section{Budaya Toleransi di Indonesia}

Masyarakat Indoensia dikenal sebagai masyalarat yang menghargai perbedaan keyakinan dan memiliki sikap toleransi yang tinggi diantara pemeluk agama. Hal ini telah dikenal dan menjadi banyak rujukan dalam membicarakan hal dialog antar umat beragama.

Toleransi adalah istilah dalam konteks sosial, budaya dan agama yang berarti sikap dan perbuatan yang melarang adanya diskriminasi terhadap kelompok-kelompok yang berbeda atau tidak dapat diterima oleh mayoritas dalam suatu masyarakat. Contohnya adalah toleransi beragama, dimana penganut mayoritas dalam suatu masyarakat mengizinkan keberadaan agama-agama lainnya. Kamus Umum Bahasa Indonesia menjelaskan toleransi dengan kelapangan dada; dalam arti suka kepada siapapun, membiarkan orang berpendapat atau berpendirian lain, tak mau mengganggu kebebasan berfikir dan berkeyakinan lain. ${ }^{138}$ Dengan banyaknya keyakinan yang diyakini umat manusia, terkadang benturan diantara mereka terjadi dan hal itu perlu ditekan sedemikian rupa sehingga kedamaian dalam kehidupan umat manusia terus terpelihara.

Istilah "Tolerance"139 atau yang dikenal sebagai "toleransi", merupakan istilah modern baik dari segi nama

138 W. J. S. Poerwodorminta, Kamus Umum Bahasa Indonesia, (Jakarta: Bina Ilmu, 1996), hlm. 4010.

${ }^{139}$ Istilah toleransi memiliki sejarah tersendiri. Pada tahun 1948, PBB Majelis Umum mengadopsi Pasal 18 dari Deklarasi Universal Hak Asasi Manusia, yang menyatakan: "Setiap orang berhak atas kebebasan berpikir, berkeyakinan dan beragama, hak ini termasuk kebebasan berganti agama atau kepercayaan, dan kebebasan, baik sendiri atau dalam komunitas dengan orang lain dan dalam praktek umum atau pribadi, untuk memanifestasikan agama atau kepercayaan dalam pengajaran, ibadah dan ketaatan". Meskipun tidak secara resmi mengikat secara hukum, deklarasi tersebut telah diadopsi banyak konstitusi nasional sejak 1948. Hal ini juga berfungsi sebagai landasan untuk semakin banyak perjanjian internasional dan hukum nasional dan lembaga internasional, regional, nasional dan sub-nasional untuk melindungi dan mempromosikan hak asasi manusia termasuk kebebasan beragama. Berbeda dengan sebelumnya, pada tahun 1965, Gereja Katolik Roma Vatikan II Konsili mengeluarkan Dekrit Dignitatis Humanae yaitu Dekrit Kebebasan Beragama yang menyatakan bahwa semua orang memiliki hak untuk kebebasan beragama. 
maupun kandungannya. ${ }^{140}$ Istilah ini pertama kali lahir di Barat, di bawah situasi dan kondisi politis, sosial dan budayanya yang khas. Untuk diketahui bahwa kata: "toleransi" berasal dari bahasa Latin, yaitu "tolerantia", yang artinya kelonggaran, kelembutan hati, keringanan dan kesabaran. Dari sini dapat dipahami bahwa toleransi merupakan sikap untuk memberikan hak sepenuhnya kepada orang lain agar menyampaikan pendapatnya, sekalipun pendapatnya salah dan berbeda. ${ }^{141}$ Istilah toleransi dikenal dengan sangat baik di dataran Eropa, terutama pada revolusi Perancis. Hal itu sangat terkait dengan slogan kebebasan, persamaan dan persaudaraan yang menjadi inti revolusi di Perancis. ${ }^{142}$ Revolusi Perancis yang berhasil meruntuhkan sistem monarki di negara itu dilakukan dengan semangat yang menjadi moto pergerakan ini, yaitu: liberté (Kebebasan), égalité (Keadilan), dan fraternité (Persaudaraan). ${ }^{143}$ Para revolusioner dari Revolusi Perancis mengambil moto liberté, égalité, fraternité, yang untuk pertama kali dipakai sebagai moto resmi negara pada 1848, oleh gubernur dari Republik Perancis yang kemudian mengadopsinya sebagai moto resmi negara pada 1880. Moto ini tertulis pada konstitusi Perancis. ${ }^{144}$

Istilah, liberté, égalité, fraternité; mempunyai kedekatan etimologis dengan istilah toleransi. Secara umum, istilah tersebut mengacu pada sikap terbuka, lapang dada, sukarela dan kelembutan. Kevin Osborn dalam buku, Tolerance,

\footnotetext{
${ }^{140}$ Anis Malik Thoha, hlm. 212.

141 Zuhairi Misrawi, Al-Qur'an Kitab Toleransi, (Jakarta : Pustaka Oasis, 2007), hlm.161.

${ }^{142}$ Ibid.

${ }^{143}$ https://id.wikipedia.org/wiki/Liberté_égalité_fr aternité, Diakses pada hari Senin, tanggal 23 Maret 2018, pukul 10.15 WIB.

${ }^{144}$ Ibid.
}

mengatakan bahwa "toleransi adalah salah satu pondasi terpenting dalam demokrasi." 145 Ketika budaya toleransi diterapkan secara salah, maka hal-hal yang berkaitan dengan esensial dalam suatu agama akan terabaikan. Karena semangat toleransi yang ada maka perlunya sikap segan dalam penyampaian iman seseorang terhadap mereka yang beragama lain. Hal inilah yang menghalangi pertumbuhan gereja. Itulah sebabnya hal ini mendapat perhatian khusus bagi mereka yang bergumul dengan teologi religionum.

M. Nasir Tamara dan Elza Pelda Taher, dalam buku Agama dan Dialog Antar Peradaban, mengatakan: "Selanjutnya, suatu dialog akan dapat mencapai hasil yang diharapkan apabila, paling tidak, memenuhi hal-hal berikut ini. adanya keterbukaan atau transparansi. Terbuka berarti mau mendengarkan semua pihak secara proporsional, adil dan setara. Dialog bukanlah tempat untuk memenangkan suatu urusan atau perkara, juga bukan tempat untuk menyelundupkan berbagai "agenda yang tersembunyi" yang tidak diketahui dengan partner dialog. ${ }^{146}$ Tamara dan Taher melihat bahwa dialog yang ada harus dilakukan dengan baik jika ingin memperoleh hasil yang diharapkan. Terkadang kegagalan terjadi karena dialog yang dilakukan tidak memenuhi hal-hal yang diharapkan sebagaimana yang disebutkan diatas. Dialog diperlukan untuk membangun hubungan yang lebih baik dalam kehidupan bermasyarakat, namun jika dialog itu pada akhirnya mengorbankan hal yang terpenting dalam kekristenan,

\footnotetext{
145 Kevin Osborn, Tolerance, (New York: InterUniversity, 1993), p.11.

${ }^{146}$ M. Nasir Tamara dan Elza Pelda Taher (ed.), Agama dan Dialog Antar Peradaban, (Jakarta: Yayasan Paramadina, 1996), hlm. 163
} 
maka hal tersebut perlu dipertimbangkan lagi.

\section{Perkembangan Pendidikan Agama Kristen di Indonesia}

Kenyataan yang tidak disangkal adalah bahwa di Indonesia terdapat sejumlah aliran dan organisasi gereja. Kesemuanya itu merupakan bentuk dari warna teologi yang berkembang dari masa ke masa. Sekolah tinggi teologi yang ada di Indonesia, terbagi dalam kelompok interdenominasional dan kelompok denominasi. Sekolah tinggi teologi yang bernafaskan sekterian agak sulit mem-baur dengan komunitas sekolah tinggi teologi lainnya. Padahal sebagai institusi pendidikan tinggi teologi, harusnya setiap sekolah tinggi teologi berperan aktif dalam upaya membangun jembatan yang terbatasi oleh tembok denominasional yang ada.

Beberapa sekolah tinggi teologi mengalami kesulitan dalam upaya membangun komunikasi dengan sekolah tinggi teologi lainnya; berkaitan dengan paham denominasi masing-masing. Dengan persoalan internal ini, maka sulit bagi setiap sekolah tinggi teologi untuk masuk dalam kajian teologi religionum. Walaupun ada beberapa sekolah tinggi yang telah membuka dan bahkan menembangkan bidang kajian teologi agama-agama, namun hingga kini masih belum mencapai hasil yang diharapkan. Diskusi-diskusi mengenai teologi agamaagama di sejumlah tempat masih belum berdampak.

Adagium Extra Yesum Christum Nulla Salus yang oleh sebagian orang meng-anggapnya sebagai sebuah pernyataan eksklusif agama Kristen; harusnya mendapat tempat untuk menjadi bahan kajian di sekolah-sekolah tinggi teologi di Indonesia. Hal ini perlu untuk mempertahankan diri dari setiap serangan yang mengatasnamakan pluralisme. Sayangnya hal tersebut bukannya dipertahankan untuk terus dikembangkan, namun pada kenyataannya umat pemimpin Gereja Katolik telah mengingkarinya melalu pernyataan resmi pada konsili Vatikan II (1962-1968). Selain itu, perkembangan teologi religionum tidak lepas dari dua gerakan besar di Eropa, yaitu: Gerakan Renaisance dan Enlightenment. Semboyan Extra Yesum Christum Nulla Salus merupakan sebuah ketegasan atas doktrin Kristen, kini mengalami distrosi.

Jika Gereja Katlolik dengan Konsili Vatikan II, maka kalangan Kristen mengakomodasi pluralisme dan menghargainya sebagai bagian dari kehidupan bermasyarakat; dimana hal tersebut tertuang dalam hasil Sidang Raya Dewan Gereja Sedunia di Upsala (1968). Sidang raya tersebut lahirkanlah sebuah kesepakatan mengenai agama-agama lain yang dianggap memiliki kesetaraan dengan kekristenan. Dengan demikian maka agama-agama lainpun mengandung kebenaran dan agama Kristen tidak bisa menyatakan dirinya sebagai satu-satunya agama yang paling benar.

Selain itu juga berkembang dengan apa yang dikenal sebagai teologi komparatif $^{147}$ yaitu suatu usaha untuk memahami arti, makna dan sumbangan iman kristiani dalam konteks keberagaman iman dengan menelitinya secara seksama dalam terang ajaranajaran tradisi agama yang lain. Berteologi dalam konteks perbandingan berarti orang-orang kristiani menganggap kebenaran-kebenaran sebagaimana diyakini oleh penganut agama lain sebagai sumber untuk memahami iman kristiani

\footnotetext{
${ }^{147}$ https://id.wikipedia.org/wiki/Teologi

_komparatif, Diakses pada hari Senin, tanggal 23 Februari 2013, pukul 11.10 WIB.
} 
mereka sendiri. Jelaslah bahwa tujuan teologi komparatif adalah membantu orang-orang kristiani untuk sampai pada pengertian yang lebih mendalam tentang tradisi iman mereka.

Teologi komparatif adalah teologi yang bertugas menginterpretasikan secara teliti tradisi kristiani dalam perjumpaan dengan teks-teks dan simbol-simbol dari agama-agama non Kristiani. ${ }^{148}$ Y.B. Prasetyanta mengutip pendapat John Renard dalam menjelaskan metodologi atau pendekatan dalam teologi komparatif berikut ini yaitu: 1) Perkembang an inter dan intra, 2) Inkulturasi dan konflik, 3) inter-tekstual, 4) pertukaran literatur dan artistik, 5) fenomenologis atau tematis, 6) hermeneutik intertekstual dan 7) perbandingan dalam metodologi dan struktur. ${ }^{149}$ Teologi komparatif mencoba untuk sampai pada kebenaran kristiani dengan menggunakan sumber dan acuan teologis yang semakin luas, termasuk unsur-unsur non kristiani, tetapi tanpa mengklaim diri mengetahui lebih banyak tentang penganut-penganut agama lain daripada para penganut agama itu mengenal diri mereka sendiri.

Perlu dipahami bahwa dalam rangka berteologi secara baik, benar dan bertanggung jawab. Hal tersebut berkaitan dengan konsistensi berteologi dalam diri seseorang. Beberapa teologi telah gagal dalam hal mengembangkan pola disuksi teologi yang lebih berkenan dihadapan Allah. Itulah sebabnya di-

148 Lihat James L. Fredericks, 'A Universal Religious Experience? Comparative Theology as an Alternative to a Theology of Religions," Horizons 22:1 (1995):68, sebagaimana dikutip oleh Y.B. Prasetyanta ,"Teologi Komparatif: Pendekatan Baru Terhadap Pluralitas Iman", Diskursus vol. 6 no. 2 Oktober (2007), hlm. 198.

149 Y. B. Prasetyanta, Y.B., "Teologi Komparatif: Pendekatan Baru Terhadap Pluralitas Iman", Diskursus vol. 6 no. 2 Oktober 2007, hlm. 201202. perlukan upaya untuk mempelajari lebih lanjut apa yang dinyatakan teologi komparatif mengeni persahabatan. Pada kenyataannya, teologi komparatif merupakan "pendekatan baru terhadap pluralitas iman." "150 dapat bekerja melalui dan dalam semangat persahabatan.

Seorang teolog yang mendukung gerakan tersebut diatas adalah teolog, teologi komparatif yang bermukim di Jepang, James L. Fredericks. Ia tinggal di Jepang dan berusaha untuk menjadi seorang ahli dalam ajaran-ajaran dan praksis agama Buddha. Fredericks berusaha menunjukkan bagaimana teologi komparatif secara wajar mengarah pada teologi dialogis. Itulah sebabnya Paul F. Knitter dengan jelas memberikan komentar atas apa yang dilakukan teolog ini sebagai berikut: "Dari pengalamannya [Fredericks] sendiri, ia menggambarkan bagaimana proses melakukan teologi komparatif ini mengarahkan umat Kristiani bukan hanya untuk meng-hayati lebih dalam berbagai ajaran agama lain, tetapi juga membangun persahabatan dengan umat beragama lain." ${ }^{151}$ Menurut Knitter, karena persahabatan dan kasih yang muncul dari ranah teologi komparatif, umat Kristiani bersedia merangkul rekan-rekan beragama lain bukan hanya untuk belajar dari mereka, tapi juga berbagi dengan memperkaya mereka.

Dengan demikian maka peran sekolah sekolah tinggi teologi di Indonesia dalam menghadapi pengajaran teologi religionum sangatlah perlu. Selain

\footnotetext{
150 Y.B. Prasetyantha menuliskan teologi komparatif ini sebagai "pendekatan baru terhadap pluralitas iman". Lihat: "Teologi Komparatif: Pendekatan Baru terhadap Pluralitas Iman," dalam jurnal Diskursus, Vol. 6, No. 2, Oktober, 2007, h. 195-208.

151 Paul F. Knitter, Pengantar Teologi Agamaagama, (Yogyakarta: Kanisius, 2008), hlm. 248.
} 
memberikan jawaban atas pergumulan teologi religionum dalam menjawab kebutuhan yang mendasar umat manusia, yaitu soteriologi, maka perlu me-mahami dengan baik tentang teologi religionum dan memberikan tempat yang lapang guna mendiskusikannya.

Teologi Religionum harus berpijak pada kebenaran Kristen yang menjadi berkat bagi agama-agama lainnya, dan bukannya menjadi bagian dari kesesatan yang sudah ada turun-temurun, dan teologi religionum merupakan sebuah gerakan yang memiliki pengalaman sejarah dari masa ke masa; berkaitan dengan upaya menjembatani hubungan yang harmonis antar agama.

\section{Sikap Keimanan PAK dalam Perkembangan Teologi Religionum}

Pendidikan Agama Kristen (PAK) tidak bisa dipisahkan dalam kehidupan orang percaya; didalamnya nyata akan pribadi Kristus sebagai titik sentral dan Alkitab sebagai dasarnya. Hal ini dianggap cukup untuk menegaskan bahwa ke-kristenan memiliki dogmatika tersendiri dan tentunya berbeda dengan agama lainnya. Paulus L. Kristanto mengutip pendepat Warner C. Graedorf yang menyatakan bahwa Pendidikan Agama Kristen adalah "Proses pengajaran dan pembelajaran yang berdasarkan Alkitab, berpusat pada Kristus, dan bergantung kepada Roh Kudus, yang membimbing setiap pribadi pada semua tingkat pertumbuhan melalui pengajaran masa kini ke arah pengenalan dan pengalaman rencana dan kehendak Allah melalui Kristus dalam setiap aspek kehidupan, dan melengkapi mereka bagi pelayanan yang efektif, yang berpusat pada Kristus sang Guru Agung dan perintah yang mendewasakan pada

Penjelasan Graedorf tersebut cukup jelas untuk menyatakan ciri khas pendidikan Kristen sehingga diluar itu akan sulit diterima. Selanjutnya mendukung pemahaman Graedorf; seorang ahli pendidikan Kristen, E. G. Homrighausen mengatakan bahwa: "Pendidikan Agama Kristen berpangkal pada persekutuan umat Tuhan. Dalam perjanjian lama pada hakekatnya dasardasar terdapat pada sejarah suci purbakala, bahwa Pendidikan Agama Kristen itu mulai sejak terpanggilnya Abraham menjadi nenek moyang umat pilihan Tuhan, bahkan bertumpu pada Allah sendiri karena Allah menjadi peserta didik bagi umat-Nya" ${ }^{\text {"153 }}$

Berkaitan dengan PAK maka kehadiran teologi religionum menjadi dilematika tersendiri dalam pelaksanaannya. Itulah sebabnya tanpa mengurangi rasa penghargaan atas keyakinan orang lain, maka PAK harus menentukan sikap. Dalam PAK, tuntutan pengakuan mutlak bahwa Yesus Kristus adalah Tuhan dan Juruselamat umat manusia; tidak bisa ditawar lagi. Finalitas Yesus Kristus sebagai Tuhan dan Juruselamat umat manusia merupakan keputusan mutlak yang didasarkan pada kebenaran wahyu Allah. Apapun alasan yang dipergunakan dalam membangun jembatan komunikasi dengan sesama pemeluk agama; PAK memberikan sikap yang jelas berkaitan dengan posisi keimanan orang percaya. Jadi hubungan dengan sesama pemeluk agama wajib dijaga dalam konteks fakta kemajemukan dalam masyarakat, namun

\footnotetext{
${ }^{152}$ Paulus Lilik Kristanto, Prinsip dan Praktek PAK Penuntun bagi Mahasiswa Teologi dan PAK, Pelayan Gereja, Guru Agama dan keluarga Kristen, (Yogyakarta : Andi Offset ), 4.

${ }^{153}$ E.G.Homrighausen, Pendidikan Agama Kristen, (Jakarta: BPK Gunung Mulia, 1985), 112
} 
keyakinan iman kepada Kristus tidak bisa diabaikan begitu saja.

\section{Kesimpulan}

Teologi Religionum dipandang sebagai salah satu solusi dalam upaya tulus untuk mempertahankan kerukunan antar umat bergama. Hal itu memungkinkan karena keyakinan teologi religionum dipandang sebagai upaya membangun jembatan komunikasi diantara umat beragama. Teologi religionum muncul karena pada kenyataan-nya, hal kemajemukan dalam masyarakat yang terus berkembang dari masa ke masa, dan perkembangan pluralistik ini sesungguhnya membutuhkan metodologi yang cocok dalam upaya membangun hubungan kemasyarakatan yang lebih baik, dan pola pendekatan yang tepat untuk menjembatani kemajemukan tersebut akan memberi dampak yang baik pula dalam kehidupan beragama.

Alan Race memperkenalkan Tipologi Tripolar sebagai upaya dalam memetakan beragam pendekatan para teolog agama-agama, termasuk teolog Kristen didalamnya. Pemetaan ini didasarkan pada kesamaan dan perbedaan cara pandang mereka terhadap agamaagama dengan upaya membangun hubungan dan komunikasi antar agama. Tipologi Tripolar dianggap mampu memberikan kontribusi yang signifikan bagi upaya membangun hubungan antar agama-agama. Dari sinilah upaya dialog bisa terbangun ketika truth claim atau klaim kebenaran pada setiap agama yang diyakini para pemeluknya perlu diredam karena memandang agamanya lebih superior atas agama lainnya merupakan penghalang bagi upaya dialog.

Beberapa momentum seperti: Teologi Liberal, Gerakan Oikmene dan bahkan Pluralisme agama telah mencatat sejarah yang penting dalam upaya membangun teologi religionum baik secara global maupun nasional. Dalam konteks Indonesia, upaya memperkenalkan teologi religionum gencar dilakukan sejumlah tokoh yang pro pluralisme. Walaupun ada tantangan yang secara terbuka namun semangat membangun teologi religionum terus berjalan dengan baik hingga saat ini.

\section{Daftar Pustaka}

Abineno. J.L. Ch., Oikumene dan Gerakan Oikumene, Jakarta: BPK Gunung Mulia,1984.

Adiprasetya. Joas, Mencari Dasar Bersama, Jakarta: BPK. Gunung Mulia, 2009.

Al-Fandi. Haryanto, Desain Pembelajaran yang Demokratis \& Humanis, Yogyakarta: Penerbit ArRuzz Media, 2011.

Ali. Syari'ati, Humanisme: antara Islam dan Mazhab Barat, terj. Afif Muhammad, cet. 2, Bandung: Pustaka Hidayah, 1996.

Amstrong. Karen, Sejarah Tuhan. Bandung: PT. Mizan Pustaka, 2012.

Bellah. N. Robert, Religi Religi Tokugawa Akar-Akar Budaya Jepang, Jakarta: Gramedia, 1992.

Bagus. Lorens, Kamus Filsafat, Jakarta: PT Gramedia Pustaka Utama, 2002.

Berger. L. Peter, Langit Suci Agama Sebagai Realitas Sosial, Jakarta: Penerbit LP3ES, 1991.

Berkhof. Louis, Teologi Sistematika Jilid 4: Doktrin Keselamatan, Jakarta: Lembaga Reformed Injili Indonesia, 1997. 
Byrne. Peter Prolegomena to Religious Pluralism, London: Macmillan Press, 1995.

Chadwick. Owen, The Secularization of the European Mind in the Nineteenth Century, New York: Cambridge University Press, 1975.

De Jonge. Christian, Menuju Keesaan Gereja: Sejarah, Dokumendokumen dan Tema-tema Gerakan Oikoumene, Jakarta: BPK Gunung Mulia, 2000.

Djaelani. Abdul Qadir, Sekitar Pemikiran Politik Islam, Jakarta: Media Da'wah, 1994.

Durkheim. Emile, Sejarah Agama: The Elementary Form Of Religious life, Yogyakarta: Isrcisod, 2001.

Eliade. Mircea (ed), The Encylopedia of Religion, New York: Collier Macmillan Publishers, 1987.

Grose. B. Geogre, dan Benjamin J. Hubbard (ed.), Tiga Agama Satu Tuhan: Sebuah Dialog, Terj. Santi Indra Astuti, Bandung: Mizan, 1998.

Gulley. Norman, Christ is Coming, New York: Review and Herald Publishing Association, tt.

Haddad. Yvonne and Wadi Haddad, Christian-Muslim Encounters, Florida: University Press of Florida, 1995.

Hick, John, Problems of Religious Pluralism, New York: St. Martin Press, 1985.

Hick, John dan Paul F. Knitter, Mitos Keunikan Agama Kristen, Jakarta: BPK Gunung Mulia, 2001.

Homrighausen. E. G., Pendidikan Agama Kristen, Jakarta: BPK Gunung Mulia, 1985.

Imarah. Muhammad, Islam Dan Pluralitas: Perbedaan Dan Kemajemukan Dalam Bingkai
Persatuan, Jakarta: Gema Insani, 1999.

Ismail. Faisal, Islam Idealitas Ilahiyah dan Realitas Insaniyah, Yogyakarta: Tiara Wacana Yogya, 1999.

Jadra. M., Pluralisme Baru dan Cinta Kebangsaan, Bandung: Penerbit Mizan, 1991.

Jura. J. Demsy, Epistemologi Kristen, Jakarta: Departemen Literatur GKKI, 2014.

Kahmad. Dadang, Sosiologi Agama, Bandung: Remaja Rosdakarya, 2006.

Khadziq, Islam Budaya Lokal Memahami Realitas Agama dalam Masyarakat, Yogyakarta: Penerbit Teras, 2009.

Knitter. F. Paul, Satu Bumi Banyak Agama; Diolog Multi-Agama dan Tanggung Jawab Global, terj. Nico A. Likumahua, Jakarta: BPK. Gunung Mulia, 2008.

Knitter. F. Paul, No Other Name?, New York: Orbis Books, 1985.

Knitter. F. Paul, Pengantar Teologi Agama-agama, Yogyakarta: Kanisius, 2008.

Kristanto. Paulus Lilik, Prinsip dan Praktek PAK Penuntun bagi Mahasiswa Teologi dan PAK, Pelayan Gereja, Guru Agama dan keluarga Kristen, Yogyakarta: Andi Offset, 2001.

Kobong. Th., Pluralisme dan Pruralisme, Jakarta: BPK. Gunung Mulia, 2003.

Lane Tony Lane, Runtut Pijar, Jakarta: BPK. Gunung Mulia, 1996.

Lewis. Bernard, What Went Wrong?: Western Impact and Middle Eastern Response, London: Phoenix, 2002.

Lumintang. I. Stevri, Theologia Abu-abu, Malang: Penerbit Gandum Mas, 2004. 
Misrawi. Zuhairi, Al-Qur'an Kitab Toleransi, Jakarta : Pustaka Oasis, 2007.

Munawar. Budhy dan Rahman, Islam Pluralis, Jakarta: Raja Grafindo Persada, 2004.

Newman. M. Barclay, A Consice GreekEnglish Dictionary of the New Testament, Stuttgart: Deutsche Bibelgesellschaft, tt.

Newbigin. Lesslie, Injil Dalam Masyarakat Majemuk, Jakarta: BPK Gunung Mulia, 2000.

O'Collins. Gerald dan Edward G. Farrugia, Kamus Teologi, Yogyakarta, Penerbit Kanisius, 1996.

Osborn. Kevin, Tolerance, New York: Inter-University, 1993.

Oxford Advanced Learner's Dictionary, New York: Oxford University Press, 1995.

Poerwodorminta. W. J. S., Kamus Umum Bahasa Indonesia, Jakarta: Bina Ilmu, 1996.

Procter. Paul (ed), Longman Dictionary Of Contemporary English, Beirut: Librairie Du Liban, 1990.

Pusat Pembinaan dan Pengembangan Bahasa, Kamus Besar Bahasa Indonesia, Jakarta: Balai Pustaka, 1999.

Qodir. Zuly, Islam Syariah vis-à-vis Negara, Yogyakarta: Pustaka Pelajar, 2007.

Riderbos. Herman, Paulus: Pemikiran Utama Teologinya, Surabaya: Penerbit Momentum, 2010.

Riyanto E. Armada, Dialog Interreligius, Yogyakarta: Kanisius, 2010.

Romly. A.M, Fungsi Agama Bagi Manusia : Suatu Pendekatan Filsafat, Jakarta: Bina Rena Pariwara, 1999.
Sartre. Jean Paul, Eksistensialisme dan Humanisme, terj. Yudhi Murtanto, Yogyakarta: Pustaka Pelajar, 2002.

Schumann. H. Olaf, Menghadapi Tantangan Memperjuangkan Kerukunan, Jakarta: BPK. Gunung Mulia, 2009.

Scruton. Roger, Sejarah Singkat Filsafat Modern: dari Descartes sampai Wittgenstein, terj. Zainal Arifin Tandjung, Jakarta: Pantja Simpati, 1984.

Shank. Andres, Civil Religion, Civil Society, Oxford: Blackweel Publisher Ltd , 1999.

Soetarman, Weinata Sairin, dan Ioanes Rakhmat, Fundamentalisme, Agama-Agama Dan Teknologi, Jakarta: BPK Gunung Mulia, 1996.

Sudiarjo, Dialog Intra Religious, Yogyakarta: Kanisus, 1994.

Sugono. Dendy (ed.), Kamus Bahasa Besar Indonesia, Jakarta: Gramedia; 2008.

Sumartana. Th. Meretas Jalan Teologia Agama-Agama di Indonesia, Jakarta: BPK. Gunung Mulia, 2007.

Sumartana. Th., Dialog, Kritik dan Identitas Agama, Jakarta: BPK. Gunung Mulia, 1996.

Sumartana. Th., "Theologia Religionum". Di dalam Meretas Jalan Teologi Agama-Agama di Indonesia. Tim Balitbang PGI (eds.). Jakarta: BPK Gunung Mulia, 2007.

Supriatno, Merentang Sejarah Memaknai Kemandirian, Jakarta:BPK. Gunung Mulia, 2009.

Suryanegara. Linda Sejarah Pemikiran Renaissance, Jakarta: Penerbit Literatur GKKI, 2011.

Tamara. M. Nasir dan Elza Pelda Taher (ed.), Agama dan Dialog Antar Peradaban, Jakarta: Yayasan Paramadina, 1996. 
Titaley. John, Menuju Teologi AgamaAgama Yang Kontekstual: Pidato Pengukuhan Guru Besar Ilmu Teologi di UKSW, Salatiga: Fakultas Teologi UKSW, tt.

Thoha. Anis Malik, Tren Pluralisme Agama: Tinjauan Kritis, Jakarta: Perspektif Kelompok Gema Insani, 2005.

Tjahjadi. L. Simon Petrus, Petualangan Intelektual. Yogyakarta: Kanisius, 2004

Wahyuninto. Liza dan Abd. Qadir Muslim, Memburu Akar Pluralisme Agama. Malang: Universitas Islam Negeri-Maliki Press: Malang. 2010.

Wirawan. H. Daniel, Mengenal Universalisme Kristen, Jakarta: Departemen Literatur GKKI, 2009.

Wright. D. F., "Theology," New Dictionary of Theology, ed. by Sinclair B. Ferguson Leicester: Inter-Varsity Press, 1994.

Yusuf. Mundzirin, Islam dan Budaya Lokal, Yogyakarta: Pokja Akademik Universita Islam Negeri Sunan Kalijaga, 2000.

https://id.wikipedia.org/wiki/Universalis me, Diakses pada hari Senin, tanggal 16 Februari 2018, pukul. 20.30 .

http://www.pgi.or.id/index.php/agendapgi/item/66-bulan-oikoumene2013. Diakses pada hari Rabu, tanggal 12 Februari 2018, pukul 20.45 WIB.

https://id.wikipedia.org/wiki/Konsili_Vat ikan_II, diakses pada hari Rabu, tanggal 12 Desember 2013, pukul 21.35 WIB.

https://id.wikipedia.org/wiki/Nostra_Aeta te, Diakses pada hari Senin, tanggal 16 Desember 2013, pukul 11.10 WIB. https://de.wikipedia.org/wiki/

Beantwortung_der_Frage:_Was_ist _Aufklärung?, Diakses pada hari Senin, tanggal 16 Februari 2018, pukul 11.10 WIB.

https://id.wikipedia.org/wiki/Dewan_Ger eja-gereja_se-Dunia, Diakses pada hari Senin, tanggal 23 Maret 2018, pukul 10.15 WIB.

https://id.wikipedia.org/wiki/Liberté_égal ité_fraternité, Diakses pada hari Senin, tanggal 23 Maret 2018, pukul 10.15 WIB.

https://id.wikipedia.org/wiki/Teologi_ko mparatif, Diakses pada hari Senin, tanggal 23 Februari 2013, pukul 11.10 WIB. 